PATRICIA AULICINO

\title{
ANÁLISE DE MÉTODOS DE AVALIAÇÃO DE SUSTENTABILIDADE DO AMBIENTE CONSTRUÍDO: O CASO DOS CONJUNTOS HABITACIONAIS
}


PATRICIA AULICINO

ANÁLISE DE MÉTODOS DE AVALIAÇÃO DE SUSTENTABILIDADE DO AMBIENTE CONSTRUIIDO: O CASO DOS CONJUNTOS HABITACIONAIS

Dissertação apresentada à Escola politécnica da Universidade de São Paulo para obtenção do título de Mestre em Engenharia.

Área de concentração: Engenharia de Construção de Civil e Urbana

Orientador: Prof. Dr. Alex Kenya Abiko

São Paulo

2008 
Este exemplar foi revisado e alterado em relação à versão original, sob responsabilidade única do autor e com anuência de seu orientador.

São Paulo, de dezembro de 2008

Assinatura do autor

Assinatura do orientador

Patricia Aulicino

Análise de métodos de avaliação de sustentabilidade do ambiente construído: o caso dos conjuntos habitacionais / P. Aulicino. - ed.rev. - São Paulo, 2008.

$157 \mathrm{p}$.

Dissertação (Mestrado) - Escola Politécnica da Universidade de São Paulo. Departamento de Engenharia de Construção Civil.

1.Desenvolvimento sustentável 2.Habitação popular 3. Avaliação de desempenho (Arquitetura) I.Universidade de São Paulo. Escola Politécnica. Departamento de Engenharia de Construção Civil II.t. 
À Madalena Pedroso Aulicino que me serve de exemplo como profissional e ser humano. 


\section{AGRADECIMENTOS}

Ao professor Alex Abiko por ter me aceitado no mestrado, pela orientação sempre objetiva, pelas oportunidades de pesquisa e trabalho sempre enriquecedoras. Ao professor Francisco Cardoso pelo apoio no trabalho de pesquisa e nas várias atividades desenvolvidas, ao professor Vanderley John pelo apoio, ao professor Racine Araújo pelas aulas de metodologia, ao professor Ricardo Moretti pela participação na banca de qualificação.

Agradeço à FAPESP pela bolsa concedida que permitiu o desenvolvimento desta pesquisa.

Agradeço ao Dr. Odair Moraes pela amizade, paciência durante estes anos de convivência.

À Kelly Inouye por todos os projetos sem os quais este trabalho não teria sido possível, e pela sua imensa fé que contagia todos a sua volta. À Clarice Degani por todas as oportunidades oferecidas. À Fátima Domingues por todo o apoio nas atividades burocráticas. À lara Negreiros pelas discussões e trabalhos durante as aulas. Ao Leonardo Figueiredo pelas entrevistas e discussões sobre sustentabilidade, ao James, ao Márcio pelo apoio com os projetos. À Salete da Hora, Melissa Hadamantine e à Holcim por incentivar a pesquisa e as práticas sustentáveis na construção civil. Agradeço a todos da sala Asteróide, Heitor Haga, Natália Macedo, Rogério Santovito - sempre ajudando em tudo, Carol Gregório, Marquinhos, Luciana Peixoto, Elisabeth Silva, Antonio Acácio, Fernanda Araújo, Flávio Maranhão, Juarez Hoppe, Leonardo Grilo, Mauricio Garcia, Ricardo, Cláudio, e a todos que contribuem para tornar a atividade de pesquisa mais enriquecedora. Ao Robson Cardoso pelos conselhos.

A todos da "família 5ways" pela compreensão, carinho e amizade num ano tão dificil!

Renata e Roberto Aulicino pelo pequeno Enzo!

Agradeço à Madalena Pedroso Aulicino pela compreensão e paciência.

Agradeço imensamente a Deus que guia a minha vida. 
"Pain is temporary. Quitting lasts forever." Lance Armstrong 


\section{Resumo}

As cidades são as grandes modificadoras da paisagem natural, uma vez que não são organismos auto-sustentáveis e sim grandes consumidores dos insumos agrícolas, industriais e dos recursos naturais, sem, no entanto, reciclá-los ou reutilizá-los. São Paulo, com quase 11 milhões de habitantes, apresenta entre outros problemas, um grande déficit habitacional, seja pela insuficiência na quantidade de habitações para atender a demanda existente, seja pela inadequação das unidades existentes. Com a finalidade de melhorar a qualidade do ambiente construído e minimizar seu impacto negativo no ambiente natural, diversas metodologias de avaliação de sustentabilidade vêm sendo desenvolvidas por diferentes países e regiões. No contexto apresentado, este artigo teve como objetivo analisar algumas destas metodologias de avaliação de sustentabilidade do ambiente construído que foram desenvolvidas internacionalmente estudando seus indicadores, estrutura e a sua aplicabilidade na avaliação de conjuntos habitacionais no contexto da realidade brasileira. A partir da revisão bibliográfica, foram selecionados alguns métodos que foram aplicados em estudos de caso formados por dois conjuntos habitacionais de interesse social produzidos pela Companhia de Desenvolvimento Habitacional e Urbano do Estado de São Paulo CDHU. Como resultado, foi possível verificar quais requisitos de sustentabilidade são atendidos pelos conjuntos e quais métodos e indicadores são aplicáveis ou não à realidade brasileira.

Palavras-Chave: sustentabilidade urbana, método de avaliação de sustentabilidade, conjuntos habitacionais de interesse social 


\begin{abstract}
Cities are the major modifier of the natural landscape, they are large consumers of agricultural inputs, industrial and natural resources, without, however, recycle it or reuse it. To improve the quality of the built environment, developed countries have designed methodologies to assess sustainability both of building constructions and urban areas. Among other problems, São Paulo, with almost 11 million inhabitants, has a significant housing deficit, both owing to the insufficiency of housing units to meet the existing demand and the low quality of existing units. In order to improve the quality of the built environment and minimize its negative impact on the natural environment, different methodologies for assessing sustainability have been developed by different countries and regions. In the presented context, the purpose of this research was to analyze some sustainable assessment methods existing internationally, reviewing their indicators, structure and its applicability in the Brazilian reality applying them to two housing schemes. With such analysis, the author has reviewed the situation of housing schemes in regard to sustainability and, at the same time, analyzed the applicability of international methods to the Brazilian reality, identifying the main difficulties of the assessments and also identifying which methods and indicators are able to be applied or not in Brazilian reality.
\end{abstract}

Keywords: sustainability of built environment, housing schemes, sustainable assessment methods 


\section{LISTA DE FIGURAS}

Figura 1 Esquema da metodologia HQE2R (Fonte: CHARLOT-VALDIEU, 2004) 37

Figura 2 Esquema do SBTool - fonte: LARSSON, 2007 45

Figura 3 Perfil do empreendimento para certificação (fonte: Vanzolini, 2007)

Figura 4 Obras de implantação do conjunto Santa Etelvina - Zona Leste

São Paulo

Figura 5 Mapa das Subprefeituras do Município de São Paulo.

Figura 6 Vista do conjunto em 2008 pelo Google Earth, o limite do conjunto é a linha branca 74

Figura 7 Planta de implantação do conjunto (fonte: CDHU) …....................... 77

Figura $8 \quad$ Gabarito completamente modificado - arquivo pessoal ..................... 78

Figura 9 Unidade original do conjunto - o proprietário não efetuou qualquer alteração - arquivo pessoal

Figura 10 Nesta unidade, o proprietário só mudou a porta da frente para o lado - arquivo pessoal

Figura 11 Área verde do conjunto - a grande inclinação do terreno, impossibilita o uso como área de lazer - arquivo pessoal.

Figura 12 Evolução da fase de construção das unidades habitacionais a partir do Google Earth com imagem de 2003 e imagem de 2008 (acesso em jan/2007 e março de 2008) 82

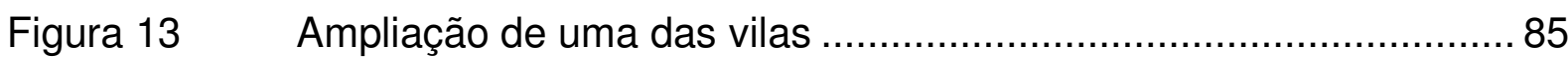

Figura 14 Implantação geral do conjunto Atibaia D ..................................... 86

Figura 15 Unidades com o equipamento para aquecimento da água por energia solar implantado.

Figura 16 Vista geral do conjunto em construção (fonte: Prefeitura de

Atibaia)

Figura 17 Vista de uma das vilas em construção pelo mutirão - arquivo pessoal 89

Figura 18 Vista de outras vilas em construção - arquivo pessoal ...................90

Figura 19 Vista das vilas acabadas do conjunto - arquivo pessoal 90 
Figura 20 Gráfico com o resultado da avaliação do Atibaia D ...................... 101

Figura 21 Gráfico com a avaliação do Marechal Tito.................................. 101

Figura 22 resultado final para o conjunto Marechal Tito .............................. 110

Figura 23 resultado final para o conjunto Atibaia D ................................... 111

Figura $24 \quad$ Matriz 1-Resumo dos indicadores estudados nos métodos........ 129

\section{LISTA DE TABELAS}

Tabela 1 Tabela com os indicadores de sustentabilidade para áreas

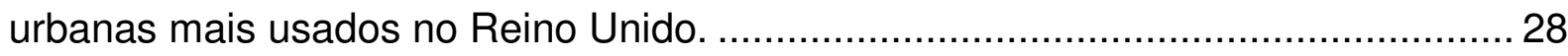

Tabela 2 Ferramentas de avaliação para áreas urbanas .................................. 30

Tabela $3 \quad$ Estrutura do sistema CODE ......................................................... 39

Tabela 4 Classificação do desempenho da habitação para a Energia e para

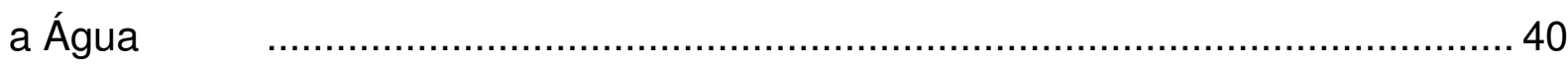

Tabela 5 Esquema de organização das categorias do método AQUA

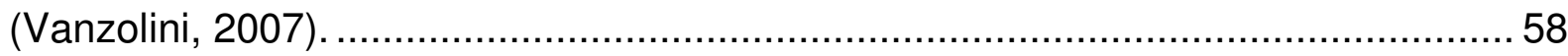

Tabela 6 Comparação entre os dois conjuntos selecionados para o estudo de caso

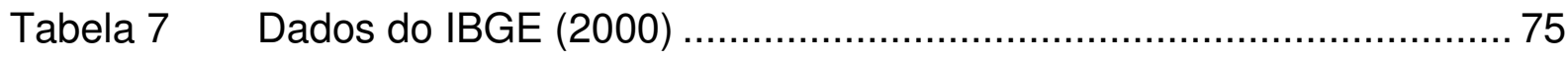

Tabela 8 Áreas e porcentagem de ocupação do terreno do Conjunto

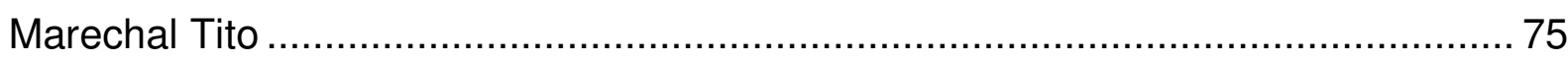

Tabela 9 Dados urbanísticos e de ocupação ………........................................... 75

Tabela 10 Distância dos principais serviços ao conjunto Marechal Tito ............ 76

Tabela 11 Detalhamento de dados do IBGE ....................................................... 80

Tabela 12 Levantamento do terreno de acordo com a CDHU ......................... 81

Tabela 13 Levantamento dos serviços no entorno do terreno .......................... 83

Tabela 14 Dados do projeto, áreas e porcentagens de cada uso...................... 88

Tabela 15 Avaliação pelo Ecohomes com suas categorias principais ............. 92

Tabela 16 Avaliação dos dois conjuntos pela categoria Social do SBAT ......... 95

Tabela 17 Avaliação pelo SBAT - categoria economia....................................... 97

Tabela 18 Avaliação pela categoria Meio Ambiente ...................................... 99

Tabela 19 Tabela mostra o peso das categorias para a avaliação dos conjuntos. 
Tabela 20 Avaliação pela primeira categoria do SBTool .............................. 104

Tabela 21 Avaliação pela categoria consumo de energia e recursos ............. 105

Tabela 22 Avaliação pela categoria cargas ambientais .............................. 107

Tabela 23 As categorias foram desativadas, nenhum dos dois conjuntos

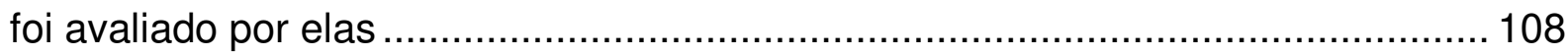

Tabela 24 Avaliação pela categoria aspectos sociais e culturais, os

econômicos não foram considerados na avaliação ........................................... 109

Tabela 25 Tabela com a avaliação das emissões ..................................... 112

Tabela 26 Avaliação pela subcategoria 1.1 do AQUA ................................114

Tabela 27 Avaliação pela subcategoria 1.2 do AQUA ...............................115

Tabela 28 Avaliação pela subcategoria 1.3 $\quad$......................................... 116

Tabela 29 Perfil geral dos conjuntos..................................................117

Tabela $30 \quad$ avaliação do método pela categoria ........................................ 119

Tabela 31 avaliação pela categoria 2 - Projeto e padrão do bairro .................121

Tabela 32 Avaliação pela categoria construção e tecnologias sustentáveis .. 125

Tabela 33 Avaliação dos conjuntos pela categoria inovação e processo de

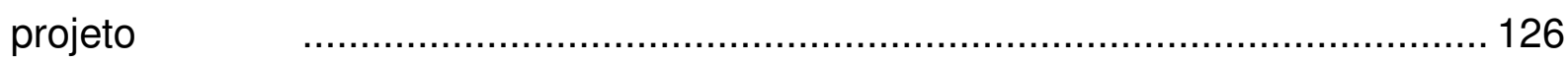

Tabela 34 Quadro resultado final dos métodos ..................................... 133 


\section{LISTA DE SIGLAS}

\begin{tabular}{|c|c|c|c|}
\hline ADEME & $\begin{array}{l}\text { Agence de l'Environnement et de la } \\
\text { Maîtrise de l'Energie }\end{array}$ & GBC & Green Building Challenge \\
\hline AEU & $\begin{array}{l}\text { Approche Environnementale de } \\
\text { l'Urbanisme }\end{array}$ & GBTool & Green Building Tool \\
\hline AQUA & Alta Qualidade Ambiental & HQE & Haute Qualité Environnementale \\
\hline BRE & Building Research Establishment & HQE2R & High Quality in Enviroment \\
\hline BREEAM & $\begin{array}{l}\text { Building Research Establishment } \\
\text { Enviromental Assessment Method }\end{array}$ & IBGE & $\begin{array}{l}\text { Instituto Brasileiro de Geografia } \\
\text { e Estatística }\end{array}$ \\
\hline CASBEE & $\begin{array}{l}\text { Comprehensive Assessment System } \\
\text { for Building Environmental Efficiency }\end{array}$ & iiSBE & $\begin{array}{l}\text { International Initiative for a } \\
\text { Sustainable Built Environment }\end{array}$ \\
\hline CBCS & $\begin{array}{l}\text { Conselho Brasileiro de Construção } \\
\text { Sustentável }\end{array}$ & IPT & $\begin{array}{l}\text { Instituto de Pesquisas } \\
\text { Tecnológicas }\end{array}$ \\
\hline CDHU & $\begin{array}{l}\text { Companhia de Desenvolvimento } \\
\text { Habitacional e Urbano }\end{array}$ & $\begin{array}{l}\text { LEED- } \\
\text { ND }\end{array}$ & $\begin{array}{l}\text { Leadership in Energy and } \\
\text { Environmental Desing - } \\
\text { Neighborhood Development }\end{array}$ \\
\hline CEC & $\begin{array}{l}\text { Commission of the European } \\
\text { Community }\end{array}$ & MMA & Ministério do Meio Ambiente \\
\hline CIB & Conseil International du Bâtiment & NF & Norme Française \\
\hline CIRIA & $\begin{array}{l}\text { Construction Industry Research and } \\
\text { Information Association }\end{array}$ & PADD & $\begin{array}{l}\text { Projet d'Aménagement et de } \\
\text { Développement Durable }\end{array}$ \\
\hline Cohab/SP & $\begin{array}{l}\text { Companhia Metropolitana de } \\
\text { Habitação de São Paulo }\end{array}$ & PLU & Plan Local d'Urbanisme \\
\hline CSTB & $\begin{array}{l}\text { Centre Scientifique et Technique du } \\
\text { Bâtiment }\end{array}$ & SAP & Standard Assessment Procedure \\
\hline DCLG & $\begin{array}{l}\text { Department for Communities and } \\
\text { Local Government }\end{array}$ & SBAT & $\begin{array}{l}\text { Sustainable Building Assessment } \\
\text { Tool }\end{array}$ \\
\hline EPA & Environment Protection Agency & SBIS & $\begin{array}{l}\text { Sustainable Building Information } \\
\text { System }\end{array}$ \\
\hline FCAV & Fundação Carlos Alberto Vanzolini & SBTool & Sustainable Building Tool \\
\hline FINEP & Financiadora de Estudos e Projeto & SEMPLA & $\begin{array}{l}\text { Secretaria Municipal de } \\
\text { Planejamento de São Paulo }\end{array}$ \\
\hline
\end{tabular}


SUMÁRIO

1. CONTEXTUALIZAÇÃO DA PESQUISA

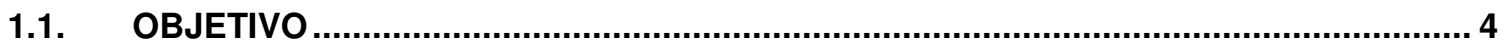

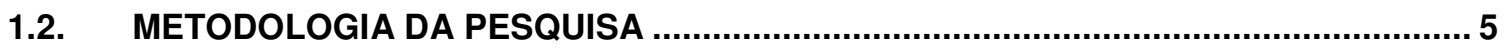

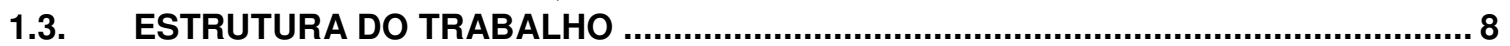

2. DESENVOLVIMENTO SUSTENTÁVEL E AMBIENTE CONSTRUÍDO...............10

3. MÉTODOS INTERNACIONAIS DE AVALIAÇÃO DE

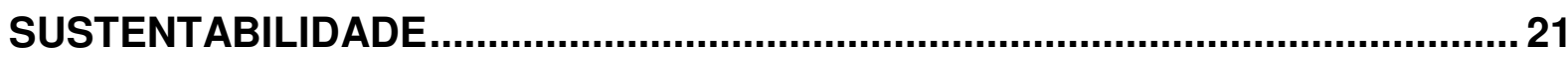

3.1. A QUESTÃO URBANA NOS MÉTODOS DE AVALIAÇÃO ……................................ 27

3.2. MÉTODOS DE AVALIAÇÃO............................................................................. 31

3.2.1. Approche Environnementale de l'Urbanisme - AEU ............................33

3.2.2. High Quality in Environment - HQE R

3.2.3. CODE for Sustainable Homes ....................................................... 38

3.2.4. Building Research Establishment Enviromental Assessment Method -

BREEAM - Ecohomes ........................................................................... 41

3.2.5. Sustainable Building Tool - SBTool.......................................... 43

3.2.6. Sustainable Building Assessment Tool - SBAT ............................... 49

3.2.7. Leadership in Energy and Environmental Design - LEED ...................50

3.2.8. Alta Qualidade Ambiental - AQUA ……………………………......56

4. O CONTEXTO DOS PAÍSES EM DESENVOLVIMENTO …...............................61

5. OS CONJUNTOS HABITACIONAIS SELECIONADOS …...............................69

5.1. O CONJUNTO HABITACIONAL MARECHAL TITO H1 ............................................ 71

5.2. O CONJUNTO HABITACIONAL ATIBAIA D ................................................... 80

6. AVALIAÇÃO DOS CONJUNTOS PELOS MÉTODOS ESCOLHIDOS................91

6.1. AVALIAÇÃO PELO BREEAM - ECOHOMES ……………..................................... 91

6.2. AVALIAÇÃO PELO SBAT .............................................................................94

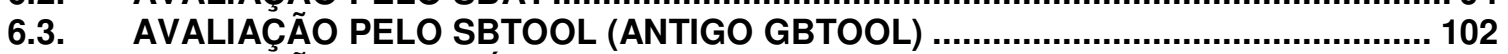

6.4. AVALIAÇÃO PELO MÉTODO AQUA ...................................................................112

6.5. AVALIAÇÃO PELO LEED-ND ................................................................... 117

7. DISCUSSÃO SOBRE OS RESULTADOS DAS AVALIAÇÕES PELOS

MÉTODOS DE SUSTENTABILIDADE E CONSIDERAÇÕES FINAIS .................. 128

7.1. A APLICABILIDADE DOS MÉTODOS.......................................................... 132

7.2. SUGESTÕES PARA ESTUDOS FUTUROS.................................................... 137

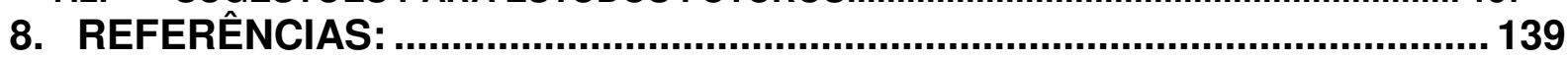




\section{CONTEXTUALIZAÇÃO DA PESQUISA}

A preocupação com o meio ambiente ganhou força a partir das crises do petróleo na década de 1970. As crises despertaram a consciência com relação à dependência dos recursos naturais e da grande demanda de energia exigida pela sociedade atual. Neste contexto, foi elaborado em 1987 o relatório Bruntland, entitulado Our common future - Nosso futuro comum - para definir um novo tipo de desenvolvimento (BRUNTLAND, 1987).

Esta definição indica um desenvolvimento em direção ao equilíbrio entre as esferas econômica, tecnológica, ambiental para uma sociedade justa e igualitária: Desenvolvimento sustentável é o "desenvolvimento que atende as necessidades das gerações atuais sem comprometer a capacidade das gerações futuras atenderem as suas próprias necessidades" (BRUNTLAND, 1987).

Após o relatório Brundtland, as Nações Unidas organizaram a United Nations Conference on Environment and Development (UNCED em 1992 - mais conhecida no Brasil como a ECO 92), com o objetivo de chegar a um entendimento de como apoiar o desenvolvimento sócio-econômico e evitar a degradação ambiental.

A partir da ECO 92 os representantes dos cento e oito países se comprometeram a adotar diretrizes para tratar do novo desenvolvimento. Uma dessas diretrizes foi denominada Agenda 21 - um programa global de ação para todos os domínios do desenvolvimento em seus diversos níveis. Na conferência de 92 foram estabelecidos os princípios globais, para que cada região, país ou estado definisse seus próprios princípios baseados nas suas necessidades e características locais.

De acordo com a Agenda 21, o principal objetivo do desenvolvimento sustentável é garantir a sobrevivência humana, constituindo um equilíbrio dinâmico entre as demandas da população por igualdade, prosperidade e qualidade de vida, dentro do que é ecologicamente possível. E para que isto seja viável, é necessário que as condições de vida no planeta sejam favoráveis (CIB \& 
UNEP, 2002).

Dessa maneira as Agendas de cada país, foram desenvolvidas, assim como as de cada estado, território ou região. Nesse sentido, não somente áreas territoriais desenvolveram sua própria Agenda, mas atividades econômicas também como é o caso da construção civil.

A construção civil é a principal responsável pelas modificações na paisagem natural, uma vez que é fornecedora de toda a infra-estrutura para o desenvolvimento das atividades humanas. Dada a importância do setor, uma Agenda para construção sustentável foi elaborada com o objetivo de criar um quadro global e uma terminologia para ajudar o desenvolvimento de agendas nacionais, regionais e locais, além servir como uma referência para atividades de pesquisa e desenvolvimento (CIB, 2000).

Seguindo esta linha, em 2002 foi definida a Agenda 21 para Construção sustentável em países em desenvolvimento, com o objetivo de discutir e entender os desafios da construção sustentável em países em desenvolvimento e formular diretrizes e estratégias de ação para que o setor da construção civil colabore no desenvolvimento destes países.

A Agenda 21 para construção sustentável em países em desenvolvimento destaca que a maioria das mega-cidades está localizada em países em desenvolvimento, onde não há investimento urbano suficiente para acompanhar o ritmo da alta taxa de crescimento demográfico.

Neste quadro, a urbanização representa uma importante questão a ser abordada, dado o crescimento demográfico constante em conjunto com o crescimento das cidades que são as grandes modificadoras da paisagem natural. As cidades atuais não são organismos auto-sustentáveis e sim grandes consumidores dos insumos agrícolas, industriais e dos recursos naturais, sem, no entanto, reciclá-los ou reutilizá-los (ANDRADE, 1998; WALSH, 2006). Com as maiores cidades do mundo ultrapassando os 10 milhões de habitantes, pode-se fazer uma idéia da complexidade dos problemas enfrentados.

Se por um lado o processo de urbanização contribuiu para a evolução e o desenvolvimento das sociedades atuais, por outro, ele modificou intensamente 0 
espaço natural gerando impactos ambientais e sociais extremamente negativos, principalmente nos países em desenvolvimento.

Nestes países, o processo de urbanização foi rápido e intenso, caracterizado pela ausência de ordenamento ou planejamento por parte do poder público e um desenvolvimento espontâneo cujas regras eram ditadas pela especulação imobiliária. Isto privilegiou o desenvolvimento de infra-estrutura de serviços para as áreas mais nobres das cidades destinadas às classes alta e média e enquanto outras áreas menos valorizadas que foram ocupadas pelas classes de menor poder aquisitivo ficaram quase ou até sem infra-estrutura urbana (ANDRADE, 1998).

No Brasil, apesar das taxas de crescimento urbano terem diminuído, as grandes metrópoles como São Paulo ainda sofrem em decorrência desta urbanização espontânea (Andrade, 1998; WERNA, 2001).

No caso de São Paulo, por exemplo, os espaços vazios desta cidade foram ocupados sem grandes preocupações por parte do poder público (Bonduki, 1994) e o crescimento desmesurado durante anos representa hoje um problema extremamente complexo para a gestão urbana, tanto em termos ambientais, como em termos econômicos, e principalmente em termos sociais.

Como problemas ambientais é possível citar:

- Desmatamento de grandes áreas para ocupação urbana gerando erosão do solo e alterações climáticas;

- Movimentos de terra alterando a drenagem das águas;

- Inundações causadas pela impermeabilização do solo;

- "Ilhas de calor" devido à grande quantidade de concreto e asfalto e devido à falta de áreas verdes;

- Emissão de resíduos sólidos contaminando a água e o solo;

- Emissão de gases causando poluição atmosférica, o efeito estufa, destruição da camada entre outros (MOTA, 1999).

Em termos sociais pode-se dizer que a questão da habitação é um grande problema das cidades de países em desenvolvimento. Uma solução encontrada por esta população extremamente pobre vai desde a produção da favela ao 
estabelecimento de um setor informal de pequena promoção imobiliária (aluguel dos cômodos do cortiço, por exemplo). Dessa forma, esta população com renda extremamente baixa (faixa da população que recebe até três salários mínimos) está sempre às margens da legislação oficial com moradias precárias em áreas de risco - encostas, por exemplo - ou de proteção de mananciais isentas de conforto ou infra-estrutura de serviços (ROCHEFORT, 1998).

Em relação à questão econômica pode-se afirmar que todos os habitantes sofrem as conseqüências deste sistema de ineficiência sobre o qual as cidades dos países em desenvolvimento estão estruturadas: a massa de excluídos contribui para aumentar o índice de violência e criminalidade, a falta de escolaridade contribui para a falta de mão-de-obra especializada, o transporte ineficiente desgasta a população ao mesmo tempo em que lhe consome preciosas horas do dia, e a falta de infra-estrutura e, conseqüentemente, dos serviços não consegue melhorar a qualidade de vida da população (PERRIN, 1974).

O primeiro passo a ser dado é levantar a situação atual em relação aos impactos do ambiente construído, analisar o heterogêneo processo de construção, que abrange desde arranha-céus inteligentes até a autoconstrução de barracos nas favelas e direcionar uma atenção especial ao problema da falta de habitação adequada. Um problema freqüente no Brasil é o déficit habitacional que pode ser subdividido em dois tipos: o déficit quantitativo, que seria a quantidade de unidades que precisam ser construídas para atender à demanda demográfica e o outro é o déficit qualitativo que representa a quantidade de unidades habitacionais consideradas inadequadas pela falta de infra-estrutura, localização precária ou pelo excesso de pessoas (CIB \& UNEP, 2002).

\subsection{OBJETIVO}

No contexto apresentado, esta pesquisa tem como objetivo discutir a aplicabilidade de alguns sistemas de avaliação de sustentabilidade do ambiente 
construído, desenvolvidos internacionalmente analisando seus indicadores, estrutura e a sua validade na avaliação de conjuntos habitacionais no contexto da realidade brasileira.

\subsection{METODOLOGIA DA PESQUISA}

Para analisar a aplicabilidade dos sistemas de avaliação foram desenvolvidas as seguintes atividades:

- Revisão bibliográfica sobre os métodos de avaliação de sustentabilidade de áreas urbanas, e de edifícios.

- Estudo de caso em que foram avaliados dois conjuntos habitacionais da Companhia de Desenvolvimento Habitacional e Urbano - CDHU: o Conjunto Habitacional Marechal Tito H1 e o Conjunto Habitacional Atibaia D.

A partir da revisão bibliográfica foi possível verificar três contextos:

- O contexto de sustentabilidade ambiental urbana nos países desenvolvidos e nos países em desenvolvimento, analisando principalmente a questão urbana e habitacional. Foram analisados principalmente o conceito de New Urbanism nos Estados Unidos e as políticas de integração do planejamento urbano aos princípios de desenvolvimento sustentável, como é o caso também da grande maioria dos países europeus

- Foi analisado o contexto internacional dos sistemas de avaliação de sustentabilidade de edifícios existentes internacionalmente, verificando e analisando seus princípios, seus indicadores, a realidade regional para o qual foi elaborado e sua aplicabilidade no contexto brasileiro.

- As diretrizes que se tem adotado para a implantação de novos 
conjuntos habitacionais, quais as dificuldades, e sua inserção na malha urbana. Foram analisados o manual de projeto técnico da CDHU e o seu projeto de Eco design que é o Atibaia D.

Foram estudados oito métodos de avaliação de edifícios e a partir da análise obtida foram selecionados cinco considerados como os mais adequados para serem utilizados na avaliação dos conjuntos habitacionais nos estudos de caso. Para escolha dos métodos utilizaram-se alguns critérios:

- Métodos já estudados internacionalmente com uma análise bibliográfica já publicada;

- Métodos que consideram em sua avaliação o edificio e o entorno, os impactos do empreendimento na vizinhança e outras características urbanas;

- Disponibilidade de acesso aos arquivos e à estrutura do método, como planilhas, lista de verificação, etc.

- Possibilidade de o método ser usado numa auto-avaliação.

Dessa maneira, algumas metodologias foram descartadas imediatamente como, por exemplo, o CASBEE, método japonês que é estritamente relacionado ao edifício, não sendo possível diferenciar os indicadores relativos à área urbana, para uma avaliação separada, como foi realizado com outros, o Nabers e o Green Star ambos da Austrália também foram excluídos por sua especificidade para o uso do método em empreendimentos australianos, o sistema é on-line e sua avaliação é feita pela internet, mas não foi possível realizá-la para o conjunto brasileiro porque os dados solicitados devem ser australianos.

Após uma primeira seleção oito métodos foram estudados, mas três deles foram descartados e a avaliação dos conjuntos foi feita pelos cinco métodos possíveis de serem aplicados aos conjuntos. Os oito métodos estudados foram:

- Approche Envinnementale d e l'Urbanisme - AEU (França)

- High Quality in Environment - $\mathrm{HQE}^{2} \mathrm{R}$ (Europa)

- CODE for sustainable homes -(Reino Unido),

- Leadership in Energy and Environmental Desing - LEED-ND (EUA)

- Building Research Establishment Environmental Assessment Method 
BREEAM - Ecohomes (Reino Unido),

- Sustainable Building Assessment Tool - SBAT (África do Sul),

- Sustainable Building Tool - SBTool (Internacional)

- Categoria 01 do método Alta QUalidade Ambiental - AQUA adaptado ao Brasil do método francês: NF batiments terciaires HQE

Os três métodos descartados foram: a metodologia AEU, por ser baseada em leis francesas que não encontram paridade na legislação brasileira, a metodologia $\mathrm{HQE}^{2} \mathrm{R}$ que foi encerrada em 2004 e teve seu website com suas principais ferramentas de avaliação desativados, e por fim a metodologia CODE que é restrita à realidade do Reino Unido. Assim, os cinco métodos selecionados para a avaliação dos conjuntos habitacionais no estudo de caso foram:

- Building Research Establishment Environmental Assessment Method - BREEAM Ecohomes (Reino Unido),

- Sustainable Building Assessment Tool - SBAT (África do Sul),

- Sustainable Building Tool - SBTool (Internacional)

- Categoria 01 do método Alta QUalidade Ambiental - AQUA adaptado ao Brasil do método francês: NF batiments terciaires HQE

- Leadership in Energy and Environmental Design - LEED-ND (EUA)

\section{Estudo de caso}

Para o estudo de caso foram escolhidos dois conjuntos habitacionais da CDHU. Os dois conjuntos foram escolhidos por apresentarem características semelhantes e dessa maneira apresentarem uma possibilidade de comparação: ambos são conjuntos habitacionais horizontais, possuem até 500 unidades habitacionais, estão localizados na periferia das cidades nas quais estão inseridos:

- Conjunto habitacional Marechal Tito H1, em Itaim Paulista - São Paulo com 488 unidades habitacionais em edifícios e casas numa área de 109.434,34m2. O conjunto foi concebido na década de 1990 e já está concluído. O conjunto faz parte da linha de projetos tradicionais da companhia, quando se construía e entregava um 
embrião para que o proprietário fizesse a ampliação como quisesse.

- Conjunto Atibaia D, com 369 unidades unifamiliares compostas por sobrados e casas térreas numa área de gleba de 83.090,360 m2; que foi concebido sob princípios de Ecodesign entre 2000 e 2002. Sua construção configura uma iniciativa pioneira da CDHU e da Prefeitura de Atibaia na aplicação destes princípios pela primeira vez num conjunto habitacional (FIGUEIREDO, 2002).

Os dois conjuntos foram avaliados com o objetivo de verificar a aplicabilidade dos métodos internacionais, e/ou seus indicadores em seus projetos. Ambos foram comparados e analisados também em relação ao desempenho sustentável apresentado de acordo com os parâmetros internacionais.

Foram avaliados itens como implantação, desenho, características urbanísticas, localização, uso eficiente da água, uso eficiente da energia, entre outros aspectos.

Os conjuntos foram avaliados por meio de consultas aos projetos obtidos junto à CDHU, levantamento de dados junto ao IBGE, entrevistas com os projetistas e visitas aos empreendimentos.

\subsection{ESTRUTURA DO TRABALHO}

A primeira parte deste texto se refere à introdução onde é feita uma contextualização da pesquisa, são apresentados os objetivos, a metodologia e em seguida, a estrutura do trabalho.

O segundo capítulo apresenta o conceito de desenvolvimento sustentável e sua relação com a urbanização, como os conceitos de desenvolvimento têm sido aplicados nas diretrizes de urbanização dos países desenvolvidos, e em desenvolvimento, por exemplo. No terceiro capítulo são apresentados os métodos estudados pela revisão bibliográfica, as características de cada um e se neste 
primeiro momento serão ou não considerados para o estudo de caso.

A partir do levantamento bibliográfico, o quarto capítulo apresenta uma contextualização geral dos países em desenvolvimento em especial o contexto brasileiro - as diretrizes adotadas, as ações tomadas em relação às diretrizes de desenvolvimento sustentável adotadas na construção civil, nas cidades e em especial na habitação para a população de baixa renda. O quinto apresenta os conjuntos Marechal Tito e Atibaia D que serão estudados no Estudo de caso no capítulo 6 em que os conjuntos são avaliados pelos cinco métodos selecionados. O sétimo apresenta uma discussão a respeito dos resultados obtidos com a avaliação dos conjuntos pelos métodos, as considerações finais e sugestão para estudos futuros. E finalmente, o oitavo capítulo contém as referências bibliográficas. 


\section{DESENVOLVIMENTO SUSTENTÁVEL E AMBIENTE CONSTRUÍDO}

A partir de alguns sérios desastres ambientais - como o derramamento durante anos de dejetos industriais com alta concentração de mercúrio na baía de Minamata, no Japão, ou como o vazamento de gases tóxicos na Índia, ou ainda com o acidente nuclear de Chernobyl (BELLEN, 2005) - o mundo começou a tomar consciência das conseqüências ambientais que as atividades humanas podem acarretar, não somente em acidentes isolados, mas de forma global também.

De acordo com Bellen (2005) inúmeras definições foram e ainda são elaboradas para o conceito de desenvolvimento sustentável. Apesar da definição do Relatório Brundtland ser uma das mais conhecidas, existem outras mais, ou menos complexas, mas que também tentam sintetizar o sentido do que seria um desenvolvimento sustentável.

Para Sachs (2002), o desenvolvimento sustentável possui várias dimensões, entre elas:

- A social - seria o alcance de uma homogeneidade social, com uma distribuição de renda justa, em que houvesse igualdade no acesso aos recursos e serviços sociais;

- Cultural - equilíbrio entre o respeito à tradição e inovação; manutenção das características locais de cada região;

- Ambiental - Ecológica - respeitar a capacidade de autodepuração dos ecossistemas naturais visando a substituição do uso de recursos não-renováveis pelos renováveis aumentando sua eficiência

- Territorial - Configurações urbanas e rurais balanceadas com a melhoria do meio-ambiente urbano; proteção à diversidade biológica concomitantemente com a qualidade de vida das pessoas;

- Econômica - desenvolvimento econômico equilibrado, autonomia de 
pesquisa científica e tecnológica;

- Política (nacional e internacional) - apropriação dos direitos humanos, nível razoável de coesão social. Co-desenvolvimento do eixo Norte-Sul, baseado no princípio da igualdade.

De acordo com o autor, o desenvolvimento sustentável, independentemente da definição de um conceito exato, é um desafio mundial, uma vez que a configuração atual do mundo está completamente desequilibrada. Na sua maioria, os países do Hemisfério Norte apresentam um padrão de consumo e emissões muito mais elevado do que no Hemisfério Sul, onde apenas uma pequena minoria apresenta um padrão de vida satisfatório.

Sachs (2007) afirma que a recuperação urbana e programas de melhoria do meio ambiente urbano deveriam ter prioridade nos planos de desenvolvimento dos países em desenvolvimento, para melhorar as condições de vida da população carente. E conseqüentemente de todos porque direta ou indiretamente todos sofrem as conseqüências de um desenvolvimento precário.

Conforme foi apresentado anteriormente, o contexto das cidades e as conseqüências econômicas, sociais e ambientais do modelo atual tem sido motivo de inúmeras discussões sobre as novas diretrizes da urbanização em direção ao desenvolvimento sustentável.

Como foi levantado, dentro do ambiente da cidade, o problema da habitação vem sendo amplamente discutido. Em 1976 foi organizada em Vancouver, Canadá, a primeira conferência para discussão dos assentamentos humanos. Desde 1978, as Nações Unidas formaram uma agência especifica para os assentamentos humanos que é a UN-Habitat. O crescimento das cidades e 0 grande número de pessoas vivendo em condições precárias já era preocupante. Vinte anos depois da primeira conferência, em 1996, foi organizada a Habitat II e a partir das discussões desta segunda conferência foi elaborada a Agenda Habitat que possui dois temas fundamentais: "habitação adequada para todos" e "desenvolvimento de assentamentos humanos sustentáveis num mundo urbanizado". Estes dois princípios visam nortear as políticas habitacionais dos países participantes dos programas. 
Para que uma cidade apresente uma qualidade de vida adequada a seus cidadãos, a gestão do desenvolvimento urbano tem que ser analisada de forma multidisciplinar, e estar alinhada com as diretrizes de sustentabilidade: ambientais, sociais, econômicas e culturais. As ambientais para garantir a preservação dos recursos naturais e o controle dos impactos ao meio ambiente, as econômicas a fim de tornar viável o desenvolvimento, as sociais cujo objetivo é valorizar o ser humano a fim de que a sociedade seja mais justa e as culturais a fim de respeitar as características específicas de cada região.

A Agenda 21 brasileira (MMA., 2004) cita a promoção de ações que visem a sustentabilidade do ambiente construído, com redução do desperdício, aumento da vida útil das construções, melhoria dos padrões de conforto ambiental e melhoria da qualidade e produtividade das obras, com participação da cadeia produtiva do setor. No entanto as diretrizes são bem gerais e as especificidades foram delegadas aos poderes locais e regionais, como o estado e o município.

Em 1990, a Comission of the European Communities - Comissão das Comunidades Européias, (CEC, 1990) elaborou o "Tratado verde sobre o ambiente urbano" com o objetivo de debater o modelo atual de organização, o desenvolvimento urbano, os impactos das cidades e as alternativas para minimizálos.

O tratado foi elaborado como um instrumento para identificar as dificuldades enfrentadas pelas conurbações européias e tentar adequar soluções para os problemas. Foram organizadas seis conferências internacionais dando prioridade a temas como

- antigas áreas industriais - áreas de atividade industrial que agora permanecem abandonadas;

- periferia urbana, produto da especulação imobiliária que jogou para os arredores da cidade pessoas com menor poder aquisitivo, em áreas carentes de infra-estrutura;

- qualidade do ambiente urbano, espaços públicos e áreas verdes. Os espaços livres das cidades estão aos poucos sendo tomados para comportar o uso dos automóveis nas áreas centrais, de outro lado as 
áreas periféricas carecem deste tipo de espaço;

- poluição urbana.

De acordo ainda com a CEC (1990) a implicação de princípios do desenvolvimento sustentável em nível local são enumeradas:

- o desenvolvimento sustentável demanda a redescoberta da ligação entre os usuários e seus contextos, analisando o projeto e o gerenciamento de cada área de maneira que reflitam a cultura local em termos de paisagem, ecologia, água e energia;

- aumento da importância funcional da localidade e diminuição da dependência em relação ao carro, significando um menor impacto por consumo de combustível fóssil, emissões e dispersão urbana;

- localidade como responsável pelo capital social da comunidade baseada em atividades locais e proximidade;

Desde a Agenda 21, questões sobre estratégias para espaço sustentável e forma urbana vêm se tornando cada vez mais importantes nos debates sobre diretrizes de planejamento como afirma Barton (2000). A primeira escala para se implantar novas diretrizes urbanas é nível da vizinhança, este é um conceito já muito antigo e tem sido retomado nos últimos anos com as novas correntes de pensamento sobre o urbanismo.

O termo vizinhança, (traduzido do termo neighborhood do inglês) tem o significado convencional de vizinhos ou pessoas do distrito ou o distrito em si mesmo. Este último significado é o termo mais encontrado e mais usado que significa uma localidade que é familiar ou tem um caráter unificante.

De acordo com Barton (2000b), a definição de neighbourhood tem ascendência decorrente dos conceitos de "cidade-jardim" de Howard no inicio do século XX. Rykwert (2004) conta que na época, os conceitos de vizinhança e cidade-jardim se confundiam. $O$ autor detalha que o termo cidade-jardim já havia sido usado antes de 1880 na Inglaterra para promover Bedford Park, no entanto do outro lado do Atlântico, nos Estados Unidos, Chicago era denominada a cidade-jardim, assim como outras pequenas cidades e subúrbios norteamericanos. Mesmo assim foi Ebenezer Howard que cunhou o termo para 
designar uma organização concêntrica de cidades hierarquizadas ao redor de uma "Cidade Central" de propriedade comum com área para agricultura nas periferias e espaços públicos e serviços no centro, sempre cercada de muito verde, este sistema deveria abrigar um máximo de duzentos e cinqüenta mil habitantes. Daí veio o termo também muito usado: cidades-satélite (Taylor, 2000), onde cada cidade seria também auto-suficiente e independente com seus próprios serviços e atividade.

Por outro lado, a definição de neighbourhood de acordo com Rykwert (2004) foi lançada nos Estados Unidos por Clarence Perry que propôs a cidade formada por diferentes unidades de vizinhança e as definiu como uma área residencial discreta com um número de famílias suficiente para preencher uma escola de ensino fundamental, algo em torno de quatro a seis mil habitantes com ruas arteriais e locais, espaços verdes e um centro que oferecesse diversos serviços para a população local.

Barton (2000b) apresenta uma outra definição de neighbourhood em seus estudos: área mista ou residencial em torno da qual as pessoas podem caminhar, onde a escala é o pedestre, é essencialmente um lugar físico, construído, pode ou não ter limites definidos nem um centro de atividades comerciais e serviços. Mas é necessário que tenha uma identidade com a qual os habitantes locais reconheçam, se identifiquem e valorizem.

Estas novas diretrizes para o urbanismo se manifestaram principalmente nos Estados Unidos que basearam todo o seu desenvolvimento urbano na escala do automóvel. A configuração do bairro americano com a casa isolada no lote e as extensas viagens do centro ao subúrbio são algumas das características percebidas atualmente como grandes inimigas do desenvolvimento sustentável: devido ao grande consumo de combustíveis fósseis e à grande quantidade de emissões atmosféricas, ao mesmo tempo em que são formados grandes congestionamentos que diminuem a produtividade e comprometem a qualidade de vida da população.

Stead (2000) ainda afirma que o impacto ambiental desta urbanização dispersa pode ser analisada usando alguns indicadores que demonstrem a 
mudança no decorrer do tempo. No caso dos países desenvolvidos ele destaca:

- o consumo de energia como principal consumidor de recursos não renováveis;

- emissão de dióxido de carbono, e outras substâncias como material particulado, dióxido sulfúrico.

- A terra urbanizada como principal depredador das terras para agricultura e de ambientes naturais, biodiversidade e impermeabilização dos terrenos

Stead também salienta uma outra conseqüência para a ocupação urbana dispersa: no caso nos paises desenvolvidos uma das grandes preocupações com a dispersão urbana é a apropriação de solo destinado à agricultura. No caso de Brasil, o grande problema é com o desmatamento de áreas de mata que acontecem com a ocupação das periferias.

Coltrinari (2006) afirma que a cidade de São Paulo e seus subúrbios possuíam uma vegetação característica: a floresta tropical úmida com árvores de espécies diversas e uma vegetação de menor porte bem variada formada por arbustos e plantas baixas. Atualmente quase nada restou deste tipo de mata na região. A retirada da cobertura vegetal, além de modificar a paisagem teve outros impactos como: erosão dos solos, escorregamentos de terra, aumento da impermeabilização do solo, e conseqüentemente do transporte de sedimentos pela água da chuva, resultando no assoreamento dos córregos e rios. Dessa maneira os rios não suportam o excesso de água e de sedimentos e transbordam resultando em enchentes, e gerando prejuízos não só ambientais, mas econômicos e sociais não só para os habitantes ribeirinhos, mas para como um todo.

No panorama atual estes impactos vêm aumentando na proporção do aumento da população urbana. A partir destes problemas, novas correntes de pensamento foram desenvolvidas para melhorar a qualidade de vida da população e ao mesmo tempo diminuir o impacto ambiental gerado pela ocupação humana. É o caso do Smarth Growth e do New Urbanism que surgiu nos Estados Unidos com a finalidade de propor novas soluções à complexa urbanização atual 
Para seguir os princípios de desenvolvimento sustentável, e desenvolver soluções ao modo de urbanização disperso sobre o qual se desenvolveram, os EUA vêm estudando novos conceitos para uma nova forma de urbanização.

De acordo com a Environmental Protection Agency - EPA do Estados Unidos, Smart Growth é o "desenvolvimento que atende a economia, a comunidade e o meio ambiente. Ele muda os termos de debate de desenvolvimento do tradicional crescimento/não crescimento para como e onde se deve acomodar um novo desenvolvimento".(EPA, 2004)

Apesar das origens do termo serem indefinidos, o conceito surgiu a partir de um movimento contra o urban sprawl (expansão urbana desordenada). O urban sprawl foi a forma dominante de desenvolvimento urbano nos Estados Unidos adotado no período pós-guerra. O termo pode ser definido como um desenvolvimento urbano com baixas densidades a longas distâncias do centro, não-planejado, baseado no automóvel, monótono e desagradável esteticamente (KNAAP \& TALEN, 2005).

Em resposta às conseqüências do Urban Sprawl, como os congestionamentos, degradação do meio ambiente e os altos custos de infraestrutura, o Smart Growth propõe uma forma e dinâmica urbanas mais compactas e menos dependentes do automóvel transformando a maneira como a cidade cresce e funciona (FILION \& McSPURREN, 2007).

Em 1996, a Environmental Protection Agency dos Estados Unidos formou a Smart Growth Network - uma rede formada por organizações de diversos setores que se uniram para discutir, elaborar, aprimorar os princípios de crescimento inteligente. Dessa maneira foram estabelecidos dez princípios, enumerados abaixo:

- Uso diversificado da terra

- Tirar proveito de projetos compactos

- Criar uma variedade de escolhas e oportunidades diferentes de habitação 
- Criar vizinhanças que sejam agradáveis para os pedestres

- Encorajar a união entre as pessoas da comunidade

- Preservar áreas ao ar livre, terras para agricultura, belezas naturais, e áreas de proteção ambiental

- Promover o desenvolvimento de comunidades já existentes

- Providenciar variedade de meios de transporte

Para padronizar o desenvolvimento das áreas urbanas a Smart Growth Network propôs o Smart Growth Index, um modelo contendo indicadores de geoprocessamento usados para simular e avaliar a sustentabilidade das escolhas feitas nos projetos. Os indicadores de desempenho são baseados nos planos de desenvolvimento e crescimento regional, nos planos de uso e ocupação do solo e transporte, nos relatórios de impacto ambiental e em projetos especiais como recuperação de áreas degradadas (TALEN, 2003; EPA ${ }^{1}$ ).

A agenda do New Urbanism é expressa no estatuto do Congress for the New Urbanism fundado em 1993 por uma coalizão de arquitetos, planejadores urbanos e pessoas ligadas ao meio ambiente (KNAAP \& TALEN, 2005). Os princípios se baseiam no desenvolvimento compacto, baseado na escala humana: distâncias pequenas da casa ao trabalho, que possam ser facilmente percorridas a pé, independência em relação ao automóvel (grande consumidor de combustível fóssil), transporte público via trem ou metro, diversos serviços e usos numa mesma área, evitando dessa maneira os grandes deslocamentos (KATZ, 1994).

O New Urbanism busca resgatar os conceitos de organização do espaço urbano anteriores ao modernismo -que organizou as cidades em setores de atividades na escala do automóvel. O movimento de New Urbanism surgiu a partir da crise de urbanização nos EUA quando havia muito incentivo do governo para ocupação do subúrbio onde o preço da terra era mais baixo que o centro. Os serviços seguiram a demanda criada pela habitação e, quando estes subúrbios alcançaram um tamanho considerável, a nova área suburbana começou a atrair empregos e os centros se esvaziaram.

${ }^{1}$ http://www.epa.gov/smartgrowth/topics/sg_index.htm. Acesso em 19/08/2007 
Stead (2000) também cita uma outra configuração em que a população se deslocou para a periferia, mas em que os centros de trabalho ainda permaneceram nos centros urbanos. A ocupação de áreas mais periféricas aumentou a distancia entre casa e trabalho, ocasionando uma série de impactos no transporte gerando um círculo vicioso onde a mudança do uso da terra aumentou a necessidade do uso dos automóveis e as longas viagens desencorajaram o uso de transportes limpos como a bicicleta ou mesmo o transporte público, alem de gerar horários de picos de deslocamentos sazonais.

O "New Urbanism" possui basicamente duas correntes de pensamento: a primeira defende que não se pode partir para novas áreas, ou para os limites do terreno até que todas as áreas estejam preenchidas. A segunda declara que a ocupação de novas áreas, de acordo com a política e a economia atual favorecem um crescimento em direção às fronteiras. Porém as duas concordam que é melhor adaptar o novo crescimento num padrão de desenvolvimento sustentável que não irá drenar a vitalidade dos centros urbanos das redondezas. (CATHORPE, 1994)

De acordo com Peter Calthorpe (1994) este movimento se preocupa tanto com o todo como com as partes. Ele aplica princípios de projeto urbano em dois sentidos: um definido pela sua diversidade, escala do pedestre, espaço público e estrutura das fronteiras dos bairros. E o segundo que toda a região deveria ser desenhada de acordo com um princípio similar de urbanismo. Deve ser ao mesmo tempo diverso e hierárquico e ter seus limites bem delimitados.

Os princípios de New Urbanism podem ser aplicados em diferentes escalas de projeto: desde a implantação de um único edifício até uma comunidade inteira. Alguns dos princípios definidos pelo Congress for the New Urbanism² podem ser definidos como:

- Prioridade aos pedestres, distâncias que podem ser percorridas em dez minutos, como, por exemplo, o trajeto de casa ao trabalho, desenho das ruas. Edifícios perto da rua, ruas com árvores, ruas com baixa velocidade, e locais específicos para estacionamento;

\footnotetext{
${ }^{2} \mathrm{O}$ Congress for the New Urbanism é uma instituição americana que tem como objetivo desenvolver soluções para combater a dispersão urbana: www.cnu.org
} 
- Conectividade. Uma malha interligada de ruas dispersa o trânsito e torna o passeio de pedestres mais agradável. Hierarquia de rua e qualidade na ligação das ruas para os pedestres;

- Diversidade de habitantes e usos: a oferta de diferentes serviços dentro do bairro ou até mesmo entre edifícios e a diversidade de habitantes em diferentes situações como renda, idade, estado civil.

- Diversidade de casas: diferentes tipos de habitações como casas grandes, pequenas, pequenos apartamentos etc;

- Qualidade de arquitetura e desenho urbano: ênfase no conforto humano, criando um senso de lugar, criação de praças e arquitetura na escala humana;

- Estrutura tradicional de bairros: percepção entre limites e centro, qualidade do espaço público, diversos usos num espaço de dez minutos de caminhada, conceito de seções transversais, com alta densidade no centro e progressiva diminuição da densidade em direção aos limites do bairro;

- Aumentar a densidade. Evitar a dispersão urbana de serviços, aproximando-os de forma que seja possível percorrer toda a variedade destes serviços a pé;

- Transporte inteligente: rede de transportes interligada, diferentes tipos de transporte e infra-estrutura que encoraje o uso de transportes limpos como bicicleta, patins, skate, etc;

- Sustentabilidade: causar o menor impacto possível ao meioambiente, usar tecnologias verdes, respeito à ecologia e ao valor dos sistemas naturais, eficiência energética, incentivo à produção local.

- Qualidade de vida: transformar o bairro num lugar em que as pessoa sintam vontade de fazer parte, com praças e locais de convivência que enriqueçam a experiência humana.

Como os princípios de Smart Growth, o conceito de New Urbanism se direciona à organização das cidades, vilas, bairros para que sejam compactas, agradáveis de serem percorridas a pé, com diferentes usos, bem sinalizadas e 
com uma boa variedade de tipologias de casas atendendo às diversas faixas de renda ao mesmo tempo em que integra as diferentes classes sociais. No entanto, Knaap e Talen (2005) afirmam que enquanto o Smart Growth foi desenvolvido por uma comunidade de ambientalistas, o New Urbanism foi desenvolvido por arquitetos e urbanistas, e em virtude disto, o movimento é mais focado na forma física, argumentando que mudanças na forma física das áreas urbanas são necessariamente um pré-requisito para as mudanças ambientais, sociais e econômicas.

O movimento é também muito criticado nos Estados Unidos porque poucos exemplos de aplicação realmente contribuíram para um padrão mais sustentável da forma urbana como destaca Beatley \& Manning (1997). Muitos dos bairros que implementaram estes princípios se localizam nos subúrbios fora da grande malha dos centros das cidades, e que acabaram por incentivar ainda mais a dispersão urbana. Apesar das críticas, o New Urbanism se disseminou nos Estados Unidos e serviu de base para o desenvolvimento de um método de avaliação de áreas urbanas que será detalhado juntamente com outros métodos no próximo capítulo. 


\section{MÉTODOS INTERNACIONAIS DE AVALIAÇÃO DE SUSTENTABILIDADE}

Larsson (2004) define os métodos de avaliação de edifícios como um conjunto de protocolos ou indicadores e critérios geralmente baseados na avaliação do ciclo de vida ${ }^{3}$ e usados para avaliar o desempenho ambiental ou de sustentabilidade de um edifício ou de seus sub-sistemas.

De acordo com Cole (2005), ferramentas e métodos de avaliação de sustentabilidade ambiental de construções surgiram para proporcionar uma avaliação objetiva do uso dos recursos naturais, da carga ecológica e da qualidade do ambiente interno, mas também para aumentar a consciência de responsabilidade ambiental no setor da construção civil.

Gibberd (2003) afirma que os métodos de avaliação possuem dois objetivos. O primeiro é assegurar que existe um entendimento adequado entre desenvolvimento sustentável, edifícios/ ambiente construído e as partes interessadas de forma que seja estabelecida uma comunicação eficiente sobre a discussão, desenvolvimento e concordância sobre os objetivos de desempenho de desenvolvimento sustentável para o edifício.

O segundo é assegurar que a relação entre desenvolvimento sustentável e ambiente construído seja explícita e inteligível. Isto inclui o entendimento de como o ambiente construído pode ser usado em favor do desenvolvimento sustentável. Isto engloba um processo de priorização dos aspectos de desenvolvimento sustentável e assegura que estes são refletidos nas metas de desempenho escolhidos para o empreendimento. Uma vez estabelecidos estas metas, a gestão do empreendimento servirá para monitorar o progresso para se alcançar os

\footnotetext{
${ }^{3}$ A análise do ciclo de vida é uma metodologia inicialmente definida pela SETAC (FAVA, 1991) como um processo para avaliar as implicações ambientais de um produto a partir da identificação e quantificação dos usos de energia e matérias-primas utilizadas e das emissões de ambientais durante todo o seu ciclo de vida, ou seja, desde a extração da matéria-prima até a disposição final do produto.
} 
objetivos determinados.

Num primeiro momento, os métodos e sistemas foram entendidos como voluntários e funcionaram como uma forma do mercado reconhecer os esforços dos empreendedores de melhorar o desempenho ambiental de seus produtos (COLE, 1999).

Nesse sentido de reconhecimento do mercado, Larsson (2004) divide os métodos em dois tipos quanto à forma que eles apresentam seu resultado:

- Rating systems: Um protocolo de avaliação que resulta em pontuação para desempenho de áreas individuais e, algumas vezes numa pontuação do desempenho total do edifício. O propósito do sistema de pontuação é fornecer uma avaliação do desempenho ambiental ou sustentável ao sistema que está sendo avaliado ou ao edifício todo. Neste último caso a soma das pontuações é solicitada.

- Labelling systems: é um sistema de pontuação como o rating system que é implementado na indústria por consultores treinados e que cada faixa de pontuação recebe um tipo de certificação de acordo com o nível alcançado de pontos. Engloba também uma estrutura mais complexa envolvendo a indústria, e diversas partes interessadas. Existe um programa de treinamento para consultores e um programa de marketing para divulgar o sistema para a indústria. É um sistema mais complexo, justamente por envolver diferentes partes interessadas. $O$ custo e a dificuldade de converter um rating system num labelling system pode ser justificado pelo fato do labeling system de ter um maior impacto de divulgação do desempenho dos edifícios para o mercado.

Apesar de Larsson identificar apenas estas duas classificações para os métodos de avaliação ainda existe um terceiro tipo que não se encaixaria em nenhuma das classificações acima. O AQUA e o NF HQE, da França são exemplos de metodologias que não possuem nenhuma das configurações acima, elas formam perfis e, para que o empreendimento consiga a certificação, é necessário que se enquadre no perfil exigido. No caso destes referenciais, não 
existe um selo com diferentes estágios de certificação e nem um sistema de soma de pontos das categorias para o alcance de um resultado final que traduzirá o desempenho do empreendimento, por isso este tipo de metodologia fica fora das classificações acima.

Cole (2005) diferencia ainda os termos ferramenta de avaliação ambiental ou de sustentabilidade de método de avaliação:

- Ferramenta de avaliação: é o termo usado para descrever uma técnica que prevê, calcula ou estima uma ou mais características de desempenho de um produto ou do edifício, como por exemplo: o uso da energia, as emissões de gases ou energia incorporada. As principais ferramentas de avaliação são baseadas na análise do ciclo de vida como a Athena Environmental Estimator e a Envest desenvolvida pelo Building Research Establishment - BRE do Reino Unido. São usadas para avaliar materiais ou outras opções de estratégias de projeto. Estas ferramentas podem ser solicitadas ou acessadas por projetistas, arquitetos ou outros profissionais ligados à área para serem usadas como e quando forem necessárias.

- Método de avaliação: é usado para descrever as técnicas em que a avaliação é sua função principal, mas que pode estar acompanhada de uma terceira parte responsável pela verificação antes da emissão da certificação ou classificação de desempenho. Ele inclui ou faz referência a uma série de ferramentas e pode oferecer programas de treinamento para profissionais de projeto.

Os termos sistema ou plano podem ser usados como sinônimos. Estes métodos são geralmente reconhecidos com planilhas que organizam ou classificam o critério de desempenho ambiental dentro de uma estrutura com pontos ou ponderação. São gerenciados e operados por contextos organizacionais como por exemplo o Building Research Establishment Enviromental Assessment Method - BREEAM operado no Reino Unido através do Building Research Establishment - BRE; o Leardership in Energy and Environmental Design - LEED pelo United States Green Building Council - USGBC. Embora algumas partes 
possam ser usadas como ferramenta de projeto pelos profissionais, o compromisso do método envolve alguma forma de registro e certificação. Esta característica representa a principal distinção entre as ferramentas e os métodos de avaliação.

Larsson (2004), afirma que os métodos de avaliação, por sua vez, tendem a ser desenvolvidos e implementados por organizações não governamentais, mesmo que seja necessário um suporte do governo para isto. Este tipo de método reflete uma abordagem que dá mais ênfase em fornecer aos empreendedores e aos projetistas um sistema que pode abranger uma variedade maior de questões como qualidade do ar interno, uso de materiais com bom desempenho ambiental e etc.

No entanto, o custo de implantação destes métodos tem se mostrado um impedimento à sua ampla aplicação. Realmente não há como escapar do fato de que a avaliação resulta em custos extras, mas a tendência indica que o mercado segue no sentido de aceitar ao menos um custo extra mínimo em troca de melhor informação e credibilidade. O problema atualmente é que dependendo da complexidade de um projeto uma certificação por um labelling system como o LEED, por exemplo, pode ter um orçamento variando de U\$20.000 a U\$ 60.000 (LARSSON, 2004; UDALL\&SCHENDLER, 2005).

É importante ressaltar que embora este alto custo exista, atualmente estes métodos funcionam como uma importante área de pesquisa do ambiente construído em que se tem tentado desenvolver com maior rigor e refinamento o desempenho dos indicadores, os protocolos de ponderação e quando apropriado, incorporar a avaliação do ciclo de vida para refinar suas medidas. (COLE, 2005). Entendendo que escopos gerais do sistema tendem a objetivar mudanças nas normas e comportamentos da indústria, além de cobrir uma ampla variedade de questões, não é surpresa que estes tipos de sistema sejam adotados como propósitos educacionais.

$\mathrm{Na}$ verdade, o que se tem observado é uma grande quantidade de projetistas se utilizando destes métodos de avaliação para desafiar suas equipes a alcançar níveis superiores de desempenho nos seus projetos ao invés de 
submetê-los à certificação formal e arcar com os altos custos envolvidos. Nos Estados Unidos, por exemplo, existe uma centena de projetos registrados no LEED project, enquanto não chegam a $10 \%$ disso os projetos certificados sob o sistema (LARSSON. 2004; UDALL\&SCHENDLER, 2005).

Esta situação reflete o fato de muitos destes projetos passarem somente parcialmente através do processo de certificação, mas também indica que à vista de vários profissionais envolvidos existe um grande benefício que pode ser obtido por meio do aprendizado dos conteúdos destes sistemas sem obrigatoriamente pagar os altos custos necessários para se preparar e obter a certificação. Todos estes sistemas estão desempenhando um importante papel na educação do mercado (LARSSON, 2004).

O Sistema LEED é um exemplo do efeito que um método pode ter sobre o mercado e sobre a indústria da construção civil norte-americana. De acordo com Silva (2003), o LEED teve uma grande aceitação da indústria da construção civil por ter sido resultado de um consenso envolvendo os diferentes atores relacionados ao setor. Sua estrutura simples como ferramenta de projeto também explica a adesão de inúmeros projetistas aos princípios ambientais avaliados pelo sistema. Um dos principais objetivos do sistema dentro deste contexto foi encorajar os diferentes atores da construção civil a desenvolver empreendimentos com alto nível de desempenho ao invés de priorizar o desenvolvimento de um sistema com um maior rigor metodológico e uma maior objetividade na avaliação do desempenho ambiental do empreendimento. E, apesar do seu sucesso em mudar a visão do mercado, algumas atitudes devem ser rapidamente tomadas para melhorar seu rigor e complementar o sistema, de forma a manter sua credibilidade a longo prazo (LARSSON, 2004).

Cole (2005) enumera outros fatores que também contribuíram para a aceitação e incorporação dos métodos de avaliação ambiental de edifícios pelos atores da construção civil:

- Ausência anterior de qualquer discussão e avaliação de desempenho ambiental das construções de uma forma compreensiva; 
- Apresentação da complexa questão dos requisitos de desempenho de uma maneira mais simplificada e de fácil entendimento;

- Uso pelas agências de setor público como demonstração de compromisso com as políticas do meio ambiente;

- Destaque de produtos e materiais de edifícios ambientalmente amigáveis no mercado.

A divulgação destes sistemas tem criado uma massa de interesse crítico, necessária para fortalecer sua função em criar uma mudança positiva. Este sucesso serve para descrever como os métodos entraram para o debate da construção civil apesar do número de empreendimentos avaliados ou certificados ser relativamente baixo até o presente momento.

Além disso, os numerosos estudos entre os métodos mais notáveis serviram para estudos de comparação entre as semelhanças e diferenças entre eles e serviram como um ponto de partida para o desenvolvimento de outros métodos de avaliação em outros países (COLE, 2005).

Dentro deste período relativamente curto os sistemas de avaliação de sustentabilidade do ambiente construído evoluíram como resultado de uma experiência acumulada, proposição teórica e novos conceitos. Neste contexto, grande parte dos métodos que antes era voltada exclusivamente para o desempenho ambiental do edifício, abriu seu leque de atuação e incorporou indicadores das áreas sociais e econômicas, re-alinhando a estrutura do método com os princípios de desenvolvimento sustentável, passando a avaliar aspectos das áreas ambiental, social e econômica. Isto requer que questões adicionais sejam cobertas, como por exemplo, níveis de renda, geração de emprego, preservação dos valores culturais e históricos. Parâmetros assim são difíceis de operacionalizar numa escala de empreendimentos pequenos; por este motivo, são mais relevante numa escala de grandes projetos, ou micro áreas urbanas.

O Sustainable Buiding Assessment Tool - SBAT foi o primeiro método de avaliação a incorporar a área social e a econômica (Larsson, 2004). Atualmente, o Green Building Tool - GBTool foi substituído pelo Sustainable Building Tool SBTool para incorporar indicadores sociais e econômicos. Seguindo a mesma 
tendência, o United States Green Building Council desenvolveu uma nova versão do sistema Leadership in Energy and Environmental Design - LEED para áreas urbanas: o Leadership in Energy and Environmental Design for Neighborhood Development - LEED-ND, com indicadores relacionados à ocupação do solo, qualidade do ambiente urbano, entre outros. Estes sistemas e versões comprovam que é necessária uma avaliação mais ampla, levando em consideração não só o empreendimento de forma isolada, mas também a relação do empreendimento com seu entorno. Esta tendência se confirma com as novas versões do Leadership in Energy and Environmental Design for New Construction - LEED NC e Leadership in Energy and Environmental Design for Core \& Shell - LEED CS que foram re-configuradas para que o empreendimento não só ofereça um menor impacto, mas que também a sua presença não seja um foco a mais de transito ou transtornos da região durante sua operação.

\subsection{A QUESTÃO URBANA NOS MÉTODOS DE AVALIAÇÃO}

Conforme foi apresentado anteriormente, o contexto das cidades e as conseqüências econômicas, sociais e ambientais do modelo atual tem sido motivo de inúmeras discussões sobre as novas diretrizes da urbanização em direção ao desenvolvimento sustentável.

Taylor (2000) afirma que existe a necessidade do desenvolvimento de processos técnicos que forneçam informações para a formação de diretrizes. Técnicas de avaliação de sustentabilidade, capacidade de carga ambiental, pegada ecológica estão sendo desenvolvidas de tal maneira que os tomadores de decisão entendam a complexidade dos cenários que lhes são mostrados. O autor também cita as listas de verificação simples usadas como um meio de tentar assegurar que todas as importantes áreas da sustentabilidade foram consideradas.

Para o desenvolvimento destas listas de verificação, os principais 
problemas urbanos foram enumerados e as soluções foram organizadas numa forma simples para serem facilmente entendidas. A grande parte dos métodos de avaliação do ambiente construído leva em consideração um tipo de lista de verificação como este na sua avaliação a fim de verificar principalmente o impacto de um novo empreendimento no meio onde será inserido. A tabela 1 demonstra os indicadores presentes num lista de verificação usado no Reino Unido. É importante observar que muitos destes indicadores estão presentes nos métodos de avaliação estudados.

Tabela 1 Tabela com os indicadores de sustentabilidade para áreas urbanas mais usados no Reino Unido.

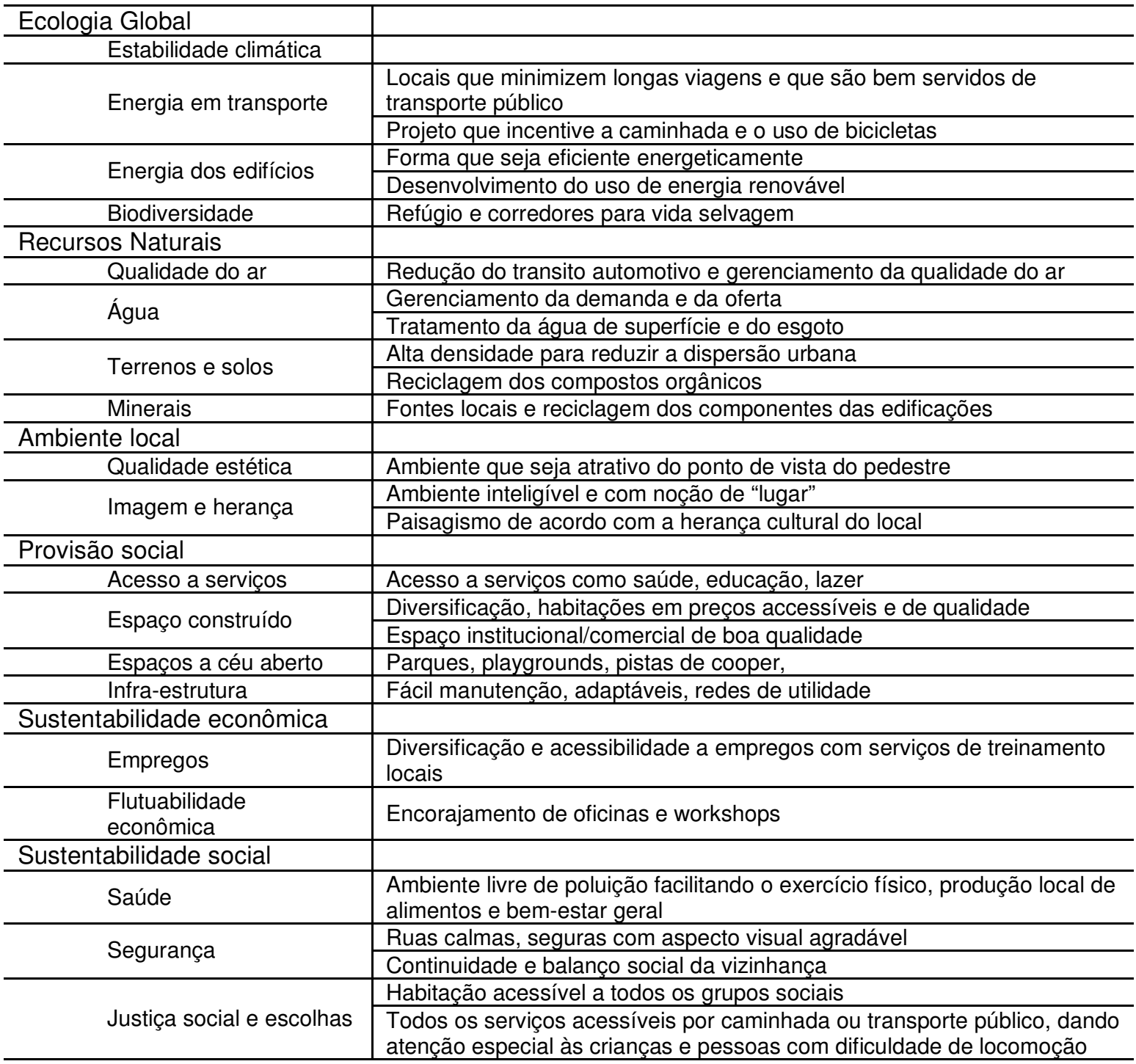


Além das listas de verificação e dos métodos de avaliação, várias ferramentas são constantemente desenvolvidas com objetivos específicos para auxiliar no planejamento de áreas urbanas, avaliando impactos ambientais, simulando o consumo de energia, entre outros objetivos.

O Sustainable Building Information System - SBIS ${ }^{4}$ é um sistema de informação que foi projetado para fornecer aos usuários informações mais detalhadas e não comerciais sobre construções sustentáveis, tecnologias, políticas e programas relacionados à construção sustentável. É possível selecionar inúmeras ferramentas de avaliação nos mecanismos de busca que o website oferece. Algumas ferramentas encontradas tratam especificamente de questões ambientais, como a quantidade de consumo de energia, ou ainda o efeito de sombreamento de um edifício a outro de uma determinada região, o nível de luminância durante o dia, o consumo de água, etc. A Tabela 2 apresenta as ferramentas de avaliação de acordo com o website do SBIS.

${ }^{4}$ www.sbis.info 
Tabela 2 Ferramentas de avaliação para áreas urbanas

\begin{tabular}{|c|c|c|c|c|c|}
\hline 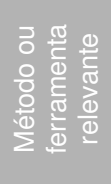 & 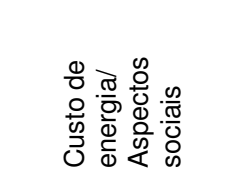 & 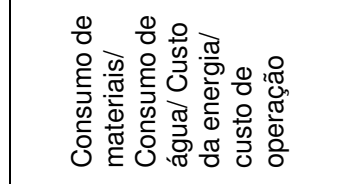 & 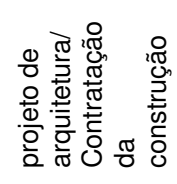 & $\frac{\$}{z}$ & 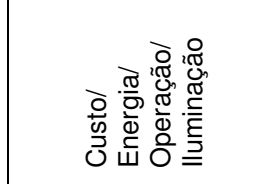 \\
\hline 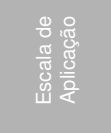 & 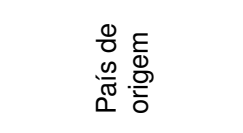 & 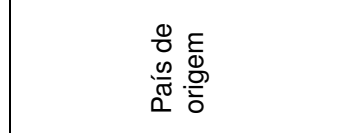 & $\begin{array}{l}\frac{0}{8} \\
\frac{E}{0} \\
\frac{\infty}{\bar{\sigma}} . \overline{0} \\
0 . \overline{0}\end{array}$ & 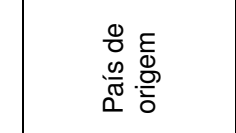 & 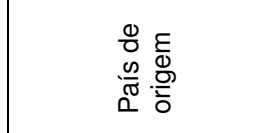 \\
\hline 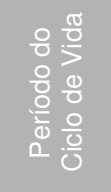 & 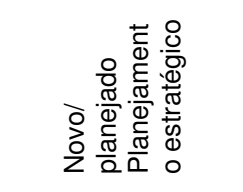 & 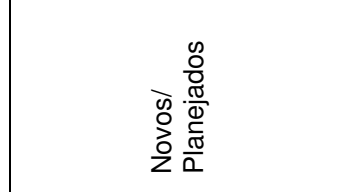 & 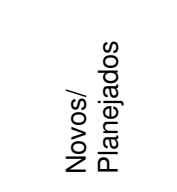 & 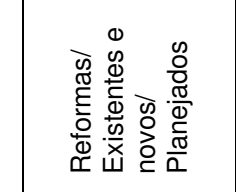 & 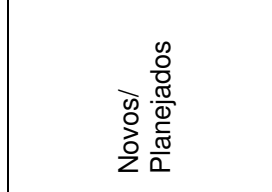 \\
\hline 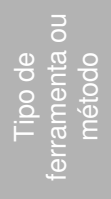 & 辤 & 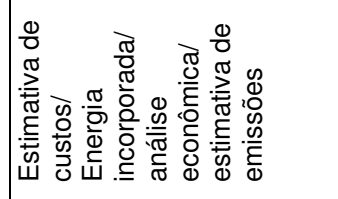 & 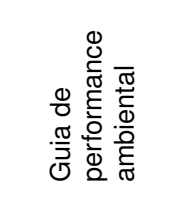 & 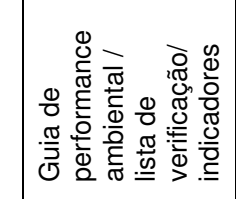 & 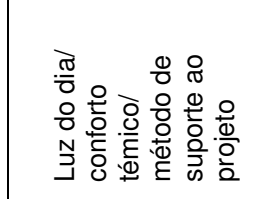 \\
\hline 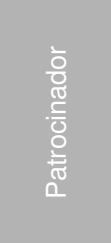 & $\frac{\mathbb{z}}{z}$ & 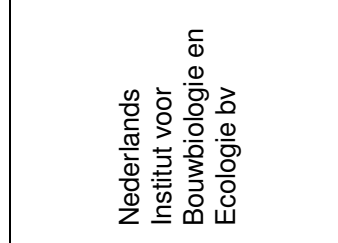 & 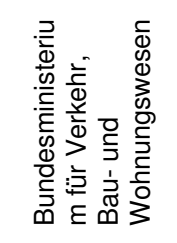 & 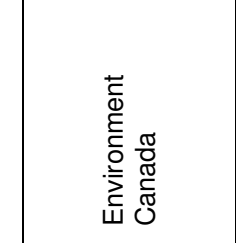 & 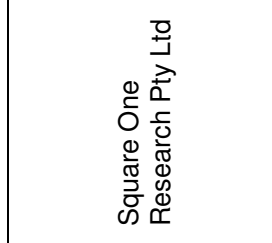 \\
\hline $\begin{array}{l}\frac{60}{10} \\
0\end{array}$ & $\begin{array}{l}\frac{\pi}{0} \\
\frac{\pi}{\pi} \\
0 \\
0\end{array}$ & $\begin{array}{l}\frac{\pi}{0} \\
\frac{0}{0} \\
\text { 오 }\end{array}$ & $\begin{array}{l}\frac{\pi}{5} \\
\frac{\pi}{\widetilde{T}} \\
\frac{\mathbb{E}}{0} \\
\frac{0}{<}\end{array}$ & $\begin{array}{l}\frac{\pi}{0} \\
\widetilde{\pi} \\
\widetilde{\pi} \\
0\end{array}$ & 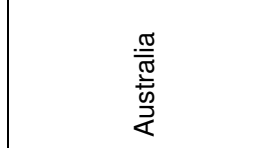 \\
\hline 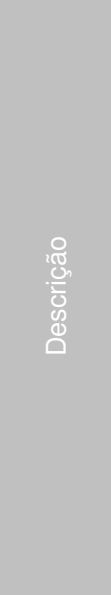 & 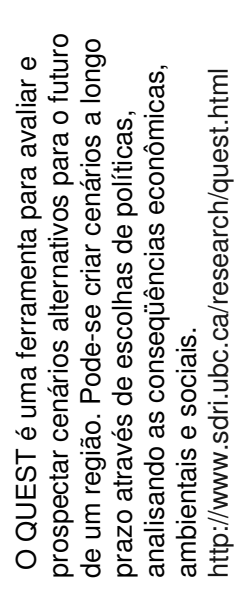 & 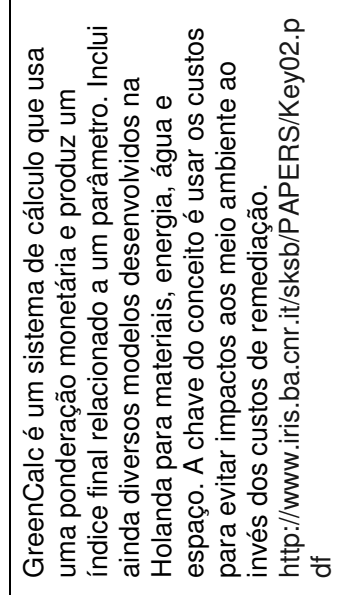 & 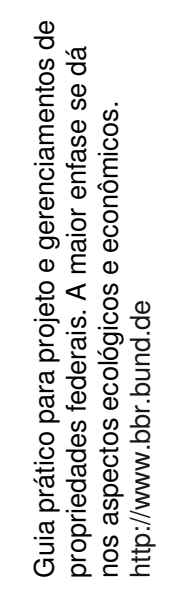 & 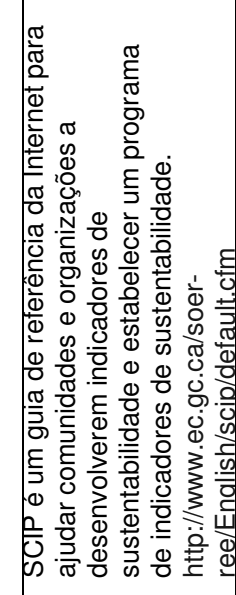 & 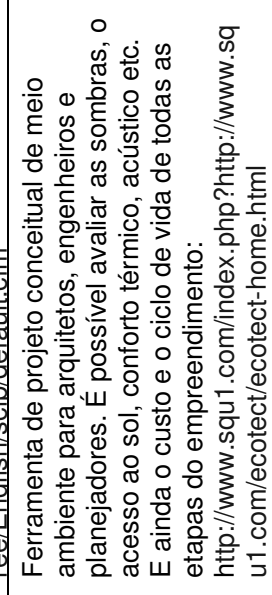 \\
\hline $\begin{array}{l}\tilde{E}_{0}^{\infty} \\
\dot{0}\end{array}$ & $\begin{array}{l}\overrightarrow{\tilde{D}} \\
\stackrel{\vec{\omega}}{\vec{O}}\end{array}$ & 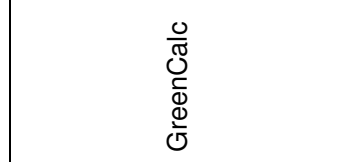 & 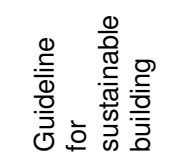 & 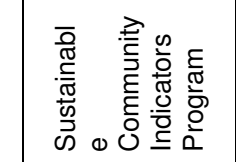 & 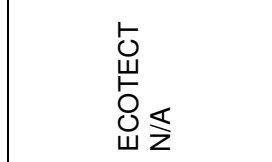 \\
\hline
\end{tabular}

Fonte: www.sbis.info 
Estes são alguns exemplos de ferramentas de avaliação específicas para áreas urbanas, todas elas são especificas ao seu país de origem, mas apresentam a possibilidade de serem aplicadas em outras regiões, como é o caso da Ecotect incorporada pela Autodesk. Como exposto, os métodos, ao contrário das ferramentas são mais completos e avaliam uma série de itens relacionados à sustentabilidade, utilizando-se algumas vezes de ferramentas ou indicadores para realizar sua avaliação. Os métodos analisados serão apresentados na seção seguinte.

\subsection{MÉTOdOS DE AVALIAÇÃO}

Nesta seção são expostos os métodos que foram estudados, ao todo foram analisadas oito metodologias, listadas a seguir:

- Leardership in Energy and Environmental Design for Neighborhood Development - LEED-ND - primeira versão do sistema LEED de avaliação para áreas urbanas

- Categoria 01 do método Alta QUalidade Ambiental - AQUA adaptado ao Brasil do método francês: NF bâtiments terciaires HQE

- Approche Environnementale de I'Urbanisme - AEU - Também desenvolvida na França é, na verdade, um conjunto de diretrizes que dá suporte ao desenvolvimento de projetos urbanísticos e tem correlação com o método HQE.

- High Quality in Environment - $H^{2} R$. O 2R corresponde a Renovação de edifícios e bairros. Iniciativa de um conjunto de sete países europeus no desenvolvimento de uma ferramenta que auxiliasse os governos locais a implementar os princípios de desenvolvimento sustentável nos projetos de áreas urbanas ou bairros.

- Building Research Establishment Enviromental Assessment Method - 
BREEAM - Ecohomes, - primeiro método a ser desenvolvido, possui alguns indicadores que tem relação do empreendimento com 0 entorno

- CODE for sustainable homes - evolução do Ecohomes para o Reino Unido lançado em 2007.

- Sustainable Building Tool - SBTool - Método que substituiu o método Green Building Tool - GBTool - consórcio internacional formado por diversos paises para o desenvolvimento de um método de avaliação sustentável de edifícios

- Sustainable Building Assessment Tool - SBAT configurou um dos primeiros métodos a serem desenvolvidos considerando as três dimensões do desenvolvimento sustentável: a ambiental, a social e a econômica.

A partir da análise das oito metodologias, três metodologias foram descartadas:

- Approche Envinmentale d'Urbanisme - AEU (França), por ser baseada em leis francesas que não encontram paridade na legislação brasileira

- High Quality in Enviroment - $\mathrm{HQE}^{2} \mathrm{R}$ (Europa), que foi encerrada em 2004 e teve seu website com suas principais ferramentas de avaliação desativados

- CODE for sustainable homes -(Reino Unido), que é restrita à realidade do Reino Unido e não apresenta oportunidade de avaliar os conjuntos habitacionais brasileiros

As cinco metodologias que foram selecionadas para aplicação aos conjuntos estão listadas a seguir:

- Building Research Establishment Environmental Assessment Method - BREEAM - Ecohomes - (Reino Unido),

- Sustainable Building Assessment Tool - SBAT (África do Sul),

- Sustainable Building Tool - SBTool (Internacional)

- Categoria 01 do método Alta QUalidade Ambiental - AQUA 
adaptado ao Brasil do método francês: NF batiments terciaires HQE

- Leadership in Energy and Environmental Desing - LEED-ND (EUA)

3.2.1. Approche Environnementale de l'Urbanisme - AEU

A Agence de l'Environnement et de la Maitrise de l'Energie - ADEME $^{5}$, entre as diversas ferramentas temáticas de planejamento do meio ambiente e das novas regulamentações fixadas aos atores do urbanismo e do ordenamento urbano desenvolveu a Approche Environnementale de l'Urbanisme -AEU para não somente contribuir no que diz respeito às exigências regulamentares em matéria de meio ambiente, mas sobre tudo para favorecer a pesquisa para desenvolvimento de um melhor meio ambiente e um consumo energético mais eficiente dentro das práticas urbanas.

A AEU permite às partes que se engajam numa metodologia de planejamento urbano ou de uma operação urbana identificar e avaliar os diferentes impactos ambientais ocasionados pelos projetos urbanos, assim como as medidas e ações necessárias para melhorá-los.

A AEU não é uma metodologia de avaliação nem um estudo de impacto ambiental: ela existe para auxiliar projetos de planejamento de áreas urbanas no que concerne ao desenvolvimento sustentável, abordando cinco áreas relacionadas ao meio urbano e ao meio ambiente natural, são elas:

- Energia;

- Deslocamentos (transportes);

- Resíduos (orgânicos e inorgânicos);

- Ruído;

- Gestão da água.

Resumidamente, a AEU pode ser esquematizada da seguinte forma:

${ }^{5}$ Agência do Meio Ambiente e Controle Energético - para definir em poucas palavras as atividades do órgão é possível defini-lo como órgão público sob a tutela conjunta dos ministérios responsáveis pela Ecologia, Energia Desenvolvimento Sustentável, do Planejamento do território e do Ministério do Ensino Superior e da Pesquisa na França (www.ademe.fr). 
É feito um inventário para identificação do contexto e inventário da oferta que tem por objetivo atualizar os principais desafios ambientais ligados ao projeto, É realizada também uma previsão da demanda futura e confrontação da demanda futura e em seguida uma divisão dos desafios a serem superados.

Após o inventário são realizadas orientações e princípios de planejamento/implantação em que são definidos os objetivos prioritários e de proposição concreta e quando uma metodologia é proposta para conduzir o empreendimento/ projeto e são realizados estudos ou avaliações complementares

Transcrição de orientações contidas nos documentos de urbanismo

- Planificação urbanística

- $\quad$ Relatório de apresentação

- $\quad$ Plano de implantação de desenvolvimento sustentável

- Documentos gráficos

- $\quad$ Regulamento e anexo do PLU

- $\quad$ Projeto de implantação operacional

- Relatório de apresentação

- $\quad$ Estudo de impacto

- Esquema de composição

- $\quad$ caderno de encargos de cessão

Definição de modalidades de acompanhamento dos projetos durante sua fase de operação

Grelhas de análise dos projetos

Indicadores de acompanhamento e avaliação

A avaliação pela metodologia não se aplica efetivamente, principalmente por esta ser baseada em leis francesas que não encontram paridade na realidade brasileira. Todas as diretrizes são embasadas na legislação francesa, no PADD e PLU que são legislações de planejamento urbano. A metodologia apresenta diversos estudos sobre, por exemplo, o espaço urbano necessário versus capacidade de transporte dos meios automotivos e ferroviários. A maior parte da metodologia é baseada na energia e o que deve ser feito para se otimizar o consumo de energia. 


\subsubsection{High Quality in Environment $-\mathrm{HQE}^{2} \mathrm{R}$}

O $\mathrm{HQE}^{2} \mathrm{R}$ foi um sistema desenvolvido para auxiliar no planejamento de novas áreas urbanas novas e na renovação de áreas urbanas existentes e suas construções. Foi uma iniciativa de pesquisa realizada em conjunto entre sete paises da Europa: França, Espanha, Itália, Alemanha, Inglaterra, Dinamarca e Holanda. A iniciativa foi pioneira e foi desenvolvida de 2001 a 2004. Até o começo do ano (2008) as ferramentas de avaliação não estavam disponíveis e agora o website foi desativado.

Foram desenvolvidos 14 estudos de caso em bairros distribuídos entre os sete países. O projeto foi parcialmente financiado pelo European Commission Programme for Energy, Environment and Sustainable Development e conduzido pelo Centre Scientifique et Technique du Bâtiment - CSTB, órgão ligado à construção civil na França (CHARLOT-VALDIEU, 2004).

A metodologia $\mathrm{HQE}^{2} \mathrm{R}$ objetiva uma renovação sustentável direcionada ao ambiente construído. Isto pode configurar uma área urbana cercada por rodovias, ou outras estruturas ou um conjunto de edifícios mais ou menos homogêneo. A $\mathrm{HQE}^{2} \mathrm{R}$ proporciona uma estrutura metodológica para análise e desenvolvimento do bairro sustentável estruturada em 4 fases:

- decisão,

- análise - identificação de prioridades definição,

- discussão e avaliação de cenários e finalmente o estabelecimento de um

- plano de ação na escala do bairro.

O objetivo do projeto foi desenvolver uma metodologia ou abordagem juntamente com métodos e ferramentas necessários para promover 0 desenvolvimento sustentável e a qualidade de vida urbana. $H^{2} E^{2} R$ desenvolveu ferramentas de ajuda à tomada de decisão para municipalidades e parcerias locais, sempre focando os habitantes da vizinhança em questão. Com esta abordagem integrada, o objetivo principal do trabalho foi o de elaborar uma 
estrutura que poderia ser aplicada nas cidades européias. O projeto usou estudo de casos como modelo de vizinhança para os quais as ferramentas foram elaboradas e na qual a abordagem ou ferramentas diferentes poderiam ser testadas (CHARLOT-VALDIEU, 2004).

O método levou em conta os seguintes elementos para uma abordagem direcionada ao desenvolvimento sustentável:

- Melhorias na qualidade dos edifícios e espaços livres

- Melhorias na qualidade de vida através do desenvolvimento urbano

- Controle de custos e uso de métodos de gerenciamento que permita a todas as partes interessadas dividir os encargos

- Controle de dispersão urbana

Outro objetivo do Projeto $\mathrm{HQE}^{2} \mathrm{R}$ é habilitar as autoridades locais a implementar planos de regeneração em suas vizinhanças e renovar o ambiente construído em acordo com o desenvolvimento sustentável. É uma questão de prover ferramentas operacionais para uma avaliação e análise concreta e seja aberta para debate e para a ação (CHARLOT-VALDIEU, 2004).

A metodologia do projeto $H Q E^{2} R$ é baseada na figura 1: 


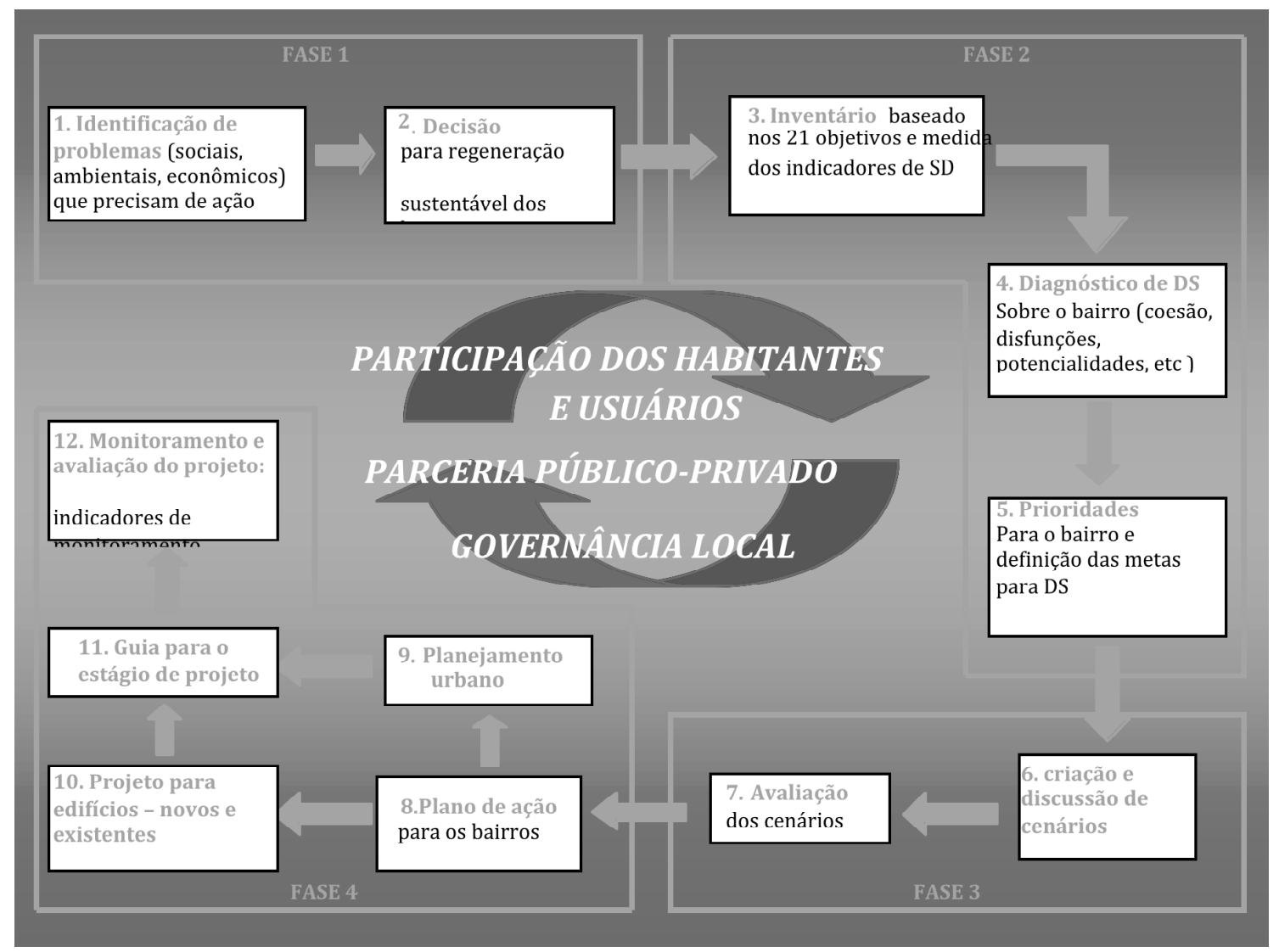

Figura 1 Esquema da metodologia HQE2R (Fonte: CHARLOT-VALDIEU, 2004)

A preocupação com a participação dos habitantes e usuários, assim como de todas as outras partes interessadas, é constante. Pode-se dizer que o processo participativo estrutura todo o projeto. No entanto, de acordo com o método, para que a população participe é preciso treiná-la e doutriná-la para que entenda as questões relativas ao desenvolvimento sustentável como fatores ambientais, sociais e econômicos. Dentre as quatro fases apresentadas na figura 1, a metodologia conta com quatro ferramentas para avaliação dos cenários (CHARLOT-VALDIEU, 2004).

Apesar da sua configuração e pioneirismo, a metodologia foi descartada por falta de informações. As ferramentas utilizadas para avaliação da situação urbana encontrada nos bairros e as outras para formulação de cenários não foram encontradas e como foi citado anteriormente o website foi desativado. 


\subsubsection{CODE for Sustainable Homes}

O principal foco do sistema é assegurar que as habitações sejam construídas de uma maneira que minimize o uso de energia e reduza o volume de emissões prejudiciais ao meio ambiente.

O objetivo é tornar-se o único padrão britânico para habitações sustentáveis, usado pelos projetistas e construtores como um guia para o desenvolvimento dos projetos e pelos consumidores para que possam dessa maneira escolher o tipo de casa de sua preferência (DCLG, 2007).

The CODE for Sustainable Homes foi preparado pelo governo inglês em conjunto com o Building Research Establishment - BRE, o Construction Industry Research and Information Association - CIRIA, o Senior Steering Group e representantes da indústria e de Organizações Não Governamentais. Ele representa uma evolução do BREEAM, para um sistema ainda mais restritivo no que se refere ao consumo de energia e água.

A curto prazo, o sistema é voluntário, mas o governo do Reino Unido estuda a possibilidade de tornar a avaliação pelo CODE como obrigatória. Algumas modificações introduzidas no CODE foram:

- O estabelecimento de um padrão mínimo para energia e uso eficiente da água em cada nível do sistema, conseqüentemente exigindo níveis mais altos de desempenho nestas áreas para atingir uma pontuação alta.

- A inclusão de novas áreas de sustentabilidade para projeto como vida útil do empreendimento e infra-estrutura para reciclagem e tratamento do esgoto (DCLG, 2007).

No entanto o sistema não deixou de ser voltado ao mercado, pois com a grande demanda de habitações que oferecem reduzido impacto ambiental, baixos custos de operação e características para melhora do bem-estar e da qualidade de vida, existe um aumento da necessidade dos construtores demonstrarem sua capacidade em construir casas sustentáveis. Neste sentido o CODE continua com 
a função do BREEAM-Ecohomes em oferecer uma ferramenta para o mercado da construção demonstrar o desempenho de seus empreendimentos.

O CODE, assim como o Ecohomes é relacionado às normas de construção. O padrão mínimo de desempenho é estabelecido pelas normas e os padrões mínimos requeridos pelo CODE ficam um nível acima destas normas (DCLG, 2007).

O sistema de avaliação é indicado por estrelas para demonstrar o desempenho de sustentabilidade total da construção. Assim, uma estrela corresponde ao nível introdutório, o mais baixo nível de desempenho e seis estrelas corresponde ao nível de excelência, o patamar mais alto a ser alcançado dentre as nove categorias entre as quais o sistema é dividido. Os padrões mínimos estão presentes para um número delas, que devem ser atingidos para se conseguir uma estrela. A eficiência no uso da água e da energia são exemplos de padrões mínimos que devem ser alcançados em todo nível do CODE.

Além destes padrões mínimos, o resto do sistema é flexível: é possível escolher quais e quantos padrões serão implementados para conseguir os pontos para a classificação final.

Tabela 3 Estrutura do sistema CODE

\begin{tabular}{|l|l|}
\hline Flexibilidade do CODE & \\
\hline Categorias & Flexibilidade \\
\hline $\begin{array}{l}\text { Energia/ CO2 } \\
\text { Água }\end{array}$ & Padrões mínimos em cada nível do Code \\
\hline $\begin{array}{l}\text { Materiais } \\
\text { Drenagem } \\
\text { Resíduos }\end{array}$ & Padrões mínimos no nível de entrada \\
\hline $\begin{array}{l}\text { Poluicão } \\
\text { Saúde e Bem-estar } \\
\text { Gerenciamento } \\
\text { Ecologia }\end{array}$ & Sem padrão mínimo \\
\hline
\end{tabular}

(Fonte: Code for Sustainable Homes: Technical Guide)

A tabela 3 demonstra a estrutura do sistema. As categorias Energia e Água exigem um pré-requisito em cada nível do CODE, do mais básico - uma estrela 
até o mais alto - seis estrelas. As categorias Materiais, Drenagem e resíduos possuem pré-requisitos somente no nível básico. Poluição, Saúde e Bem-estar, Gerenciamento e Ecologia não possuem pré-requisito nenhum (DCLG, 2007).

A tabela 4 exemplifica melhor a pontuação das categorias energia e água.

Tabela 4 Classificação do desempenho da habitação para a Energia e para a Água Adquirindo uma ceritifação de sustentabilidade

Padrões mínimos

\begin{tabular}{lllll|l}
\hline & Energia & \multicolumn{5}{c|}{ Água } \\
\hline Nivel do Code & Padrão & Pontos ganhos & Padrão & Pontos ganhos & $\begin{array}{l}\text { Outros pontos } \\
\text { adquirdos }\end{array}$ \\
\hline $1(\star)$ & 10 & 1,2 & 120 & 1,5 & 33,3 \\
\hline $2(\star \star)$ & 18 & 3,5 & 120 & 1,5 & 43,0 \\
\hline $3(\star \star \star)$ & 25 & 5,8 & 105 & 4.5 & 46,7 \\
\hline $4(\star \star \star \star)$ & 44 & 9,4 & 105 & 4,5 & 64,1 \\
\hline $5(\star \star \star \star \star)$ & $100^{1}$ & 16,4 & 80 & 7,5 & 64,9 \\
\hline $6(\star \star \star \star \star \star)$ & $\begin{array}{l}\text { Habitação } \\
\text { Carbono }\end{array}$ & 17,6 & 80 & 7,5 & \\
\hline
\end{tabular}

Notas:

1. Zero emissões em relação às questôes de legislação das edificações (por exemplo: emissão zero proveniente de aquecimento, água quente, ventilação e iluminação)

2. Uma habitação completamente sem emissão de carbono (por exemplo:zero emissões de dióxido de carbono $\mathrm{CO} 2$ proveniente do uso de qualquer fonte de energia na habitação)

3. Todos os pontos foram aproximados a uma casa decimal apenas

(Fonte: Code for Sustainable Homes: Technical Guide)

A tabela 4 mostra os padrões mínimos, e o número de pontos necessários para se conseguir chegar a cada nível do CODE.

A metodologia foi uma evolução do Econhomes para um nível de exigência ainda maior nas categorias de água e energia, e para uma restrição à região de aplicação que é a Inglaterra. Assim como o BREEAM, a avaliação por emissão de CO2 é baseada no Standard Assessment Procedure - SAP, uma metodologia aprovada pelo governo para avaliar o desempenho das habitações britânicas.

Cada crédito do CODE se divide em fase de projeto e fase de pósconstrução, e por talvez por este motivo não exista uma planilha para auto- 
avaliação que existe no BREEAM em que são fornecidas as porcentagens possíveis de serem alcançadas em cada crédito.

A possibilidade da realização de uma auto-avaliação configura um prérequisito para a seleção do método, como o CODE não apresenta esta alternativa, o método foi descartado.

3.2.4. Building Research Establishment Enviromental Assessment Method BREEAM - Ecohomes

O primeiro método de avaliação ambiental de edifícios surgiu em 1990 no Reino Unido, desenvolvido pelo Building Research Establishment - BRE e batizado como Building Research Establishment Environmental Assessment Method - BREEAM (SILVA, 2003).

O sistema avalia o desempenho dos edifícios nas seguintes áreas:

- Gerenciamento: gerenciamento das diretrizes gerais, dos procedimentos;

- Uso da energia: gestão da energia e do dióxido de carbono;

- Saúde e bem-estar: questões internas e externas ao empreendimento que afetem a saúde e bem-estar do indivíduo;

- Poluição: poluição do ar e da água;

- Transporte: relação transporte e $\mathrm{CO} 2$ e fatores relacionados à localização;

- Uso da terra: áreas verdes e contaminadas;

- Ecologia: conservação e aumento do valor ecológico do terreno;

- Materiais: impacto ambiental dos materiais do edifício incluindo a análise do ciclo.de vida;

- Água: consumo e uso eficiente da água.

Após submetido ao processo de avaliação, o empreendimento recebe uma pontuação, de acordo com o seu desempenho. Essa pontuação the dá uma 
classificação que pode ser: Pass (aprovado), o nível mais baixo, Good (Bom), Very Good (muito bom) e Excelent (excelente), o nível mais alto. $O$ empreendimento recebe então um certificado de acordo com a sua classificação. Dessa maneira, a certificação pode ser usada como uma promoção comercial do empreendimento ou até uma forma de se conseguir financiamentos (BRE, 2006).

Para atender à crescente demanda, o sistema desenvolveu uma versão para cada tipo de edifício:

- BREEAM offices: Empreendimentos de escritórios;

- BREEAM Ecohomes: Habitações;

- BREEAM Courts: Fóruns judiciários;

- BREEAM Industrial: Edifícios industriais;

- BREEAM Prisons: Prisões;

- BREEAM Retail: Shopping Centers;

- BREEAM School: Escolas;

- BREEAM EcohomesXB: Reformas de habitações;

- BREEAM Multi-residential: Edifícios multiresidenciais, como alojamento para estudantes, creches, etc.;

- BREEAM Bespoke: avalia todos os edifícios não relacionadas acima, como por exemplo hotéis, teatros, etc.;

Para esta pesquisa a versão utilizada foi o BREEAM Ecohomes.

Como uma forma de auxiliar os projetistas a desenvolverem seus projetos antes de submetê-los à avaliação, foi criado o Ecohomes Pré-Assessment Estimator que pode ser usado como uma auto-avaliação para entender o que vai ser solicitado e analisar o nível de informação exigido pelo certificador. Ele demonstra em forma de porcentagens quanto poderia ser atingido pelo projeto no caso de uma avaliação (BRE, 2006).

Assim como as outras versões do BREEAM, o Ecohomes é dividido em categorias, onde cada uma possui uma série de indicadores que fornecem os pontos conforme os critérios são atendidos ou não. As principais categorias são:

- Energia;

- Transporte; 
- Poluição;

- Materiais;

- Água;

- Uso do solo e ecologia;

- Saúde e bem-estar;

- Gerenciamento;

Para a avaliação pelo BREEAM, o BRE (2006) recomenda que sua adesão seja feita o mais cedo possível, de preferência com o programa de necessidades . Dessa maneira um certificador é contatado já na fase de pré-projeto para que as características do Ecohomes possam ser incorporadas mais facilmente no processo de desenvolvimento gerando dessa forma o menor custo nas alterações que tenham que ser feitas, caso ocorram.

Este método procura balancear desempenho ambiental com boa qualidade de vida e um ambiente interno saudável e seguro. Muito dos créditos são opcionais, deixando o método flexível o suficiente para servir para um desenvolvimento específico ou ainda para o mercado.

Pode ser aplicado tanto na fase de projeto como na fase de pós-construção do empreendimento para novos projetos ou reforma de existentes. O método cobre todos os padrões de casa em desenvolvimento na Inglaterra, Escócia, País de Gales e Irlanda do Norte:

- Conjuntos habitacionais públicos e privados

- Flats, apartamentos e casa

- Novos edifícios e reformas de antigas habitações

Em abril de 2007 o CODE for Sustainable Homes substituiu o BREEAM Ecohomes para a avaliação de novas habitações na Inglaterra. Neste período de transição o BRE manterá o Ecohomes, que continuará sendo usado para reformas na Inglaterra e para todos os tipos de habitação na Escócia e no País de Gales.

3.2.5. Sustainable Building Tool - SBTool

O SBTool é um sistema baseado em planilhas anteriormente conhecido 
como Green Building Tool - GBTool, que foi projetado para avaliar o desempenho ambiental e de sustentabilidade dos edifícios. O SBTool é um método de avaliação que está em desenvolvimento desde 1996 por um grupo de mais de doze equipes internacionais. O processo do GBC foi inicialmente desenvolvido pelo Natural Resources Canada, mas a responsabilidade foi depois delegada para o International Initiative for a Sustainable Built Environment - iiSBE em 2002. O método genérico e a ferramenta são calibrados pelas equipes nacionais a fim de se adaptar às condições locais, e é então testado em edifícios que funcionam como estudos de caso. Os resultados são divulgados nas conferências internacionais Sustainable Building - SB, que são divididas em conferências regionais e mundiais. A mais recente aconteceu em setembro de 2008 em Melbourne na Austrália.

Apesar da prioridade do iiSBE ser a pesquisa, o desenvolvimento e a dedicação em ajudar equipes regionais a superar e a entender os desafios da avaliação de desempenho, ele também se disponibiliza a avaliar empreendimentos de base comercial.

Por ser uma iniciativa de pesquisa internacional, o SBTool possui uma estrutura genérica e deve ser visto como um método genérico que permite às organizações locais desenvolverem um ou mais sistemas de avaliação baseados em sua estrutura, mas que se adaptam à região. O método permite a usuários autorizados estabelecerem um escopo para avaliação para que o sistema retrate a importância relativa às questões de desempenho numa determinada região e também para que este sistema contenha parâmetros regionalmente relevantes. Ao substituir os parâmetros genéricos pelos próprios, as autoridades regionais podem assegurar que o sistema será relevante para condições locais específicas. 


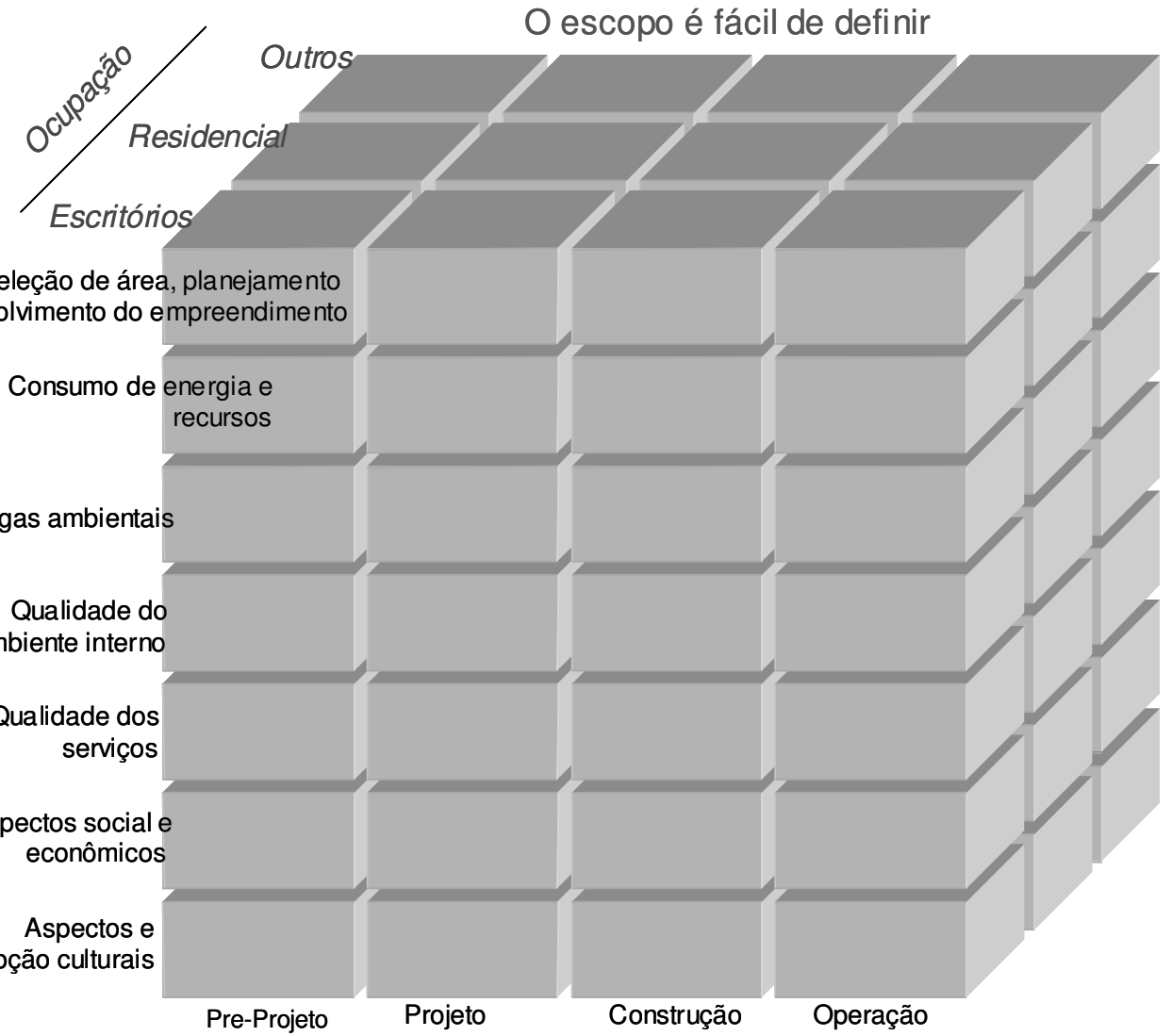

... uma forma que atenda os requisitos de um edificil sustentável....

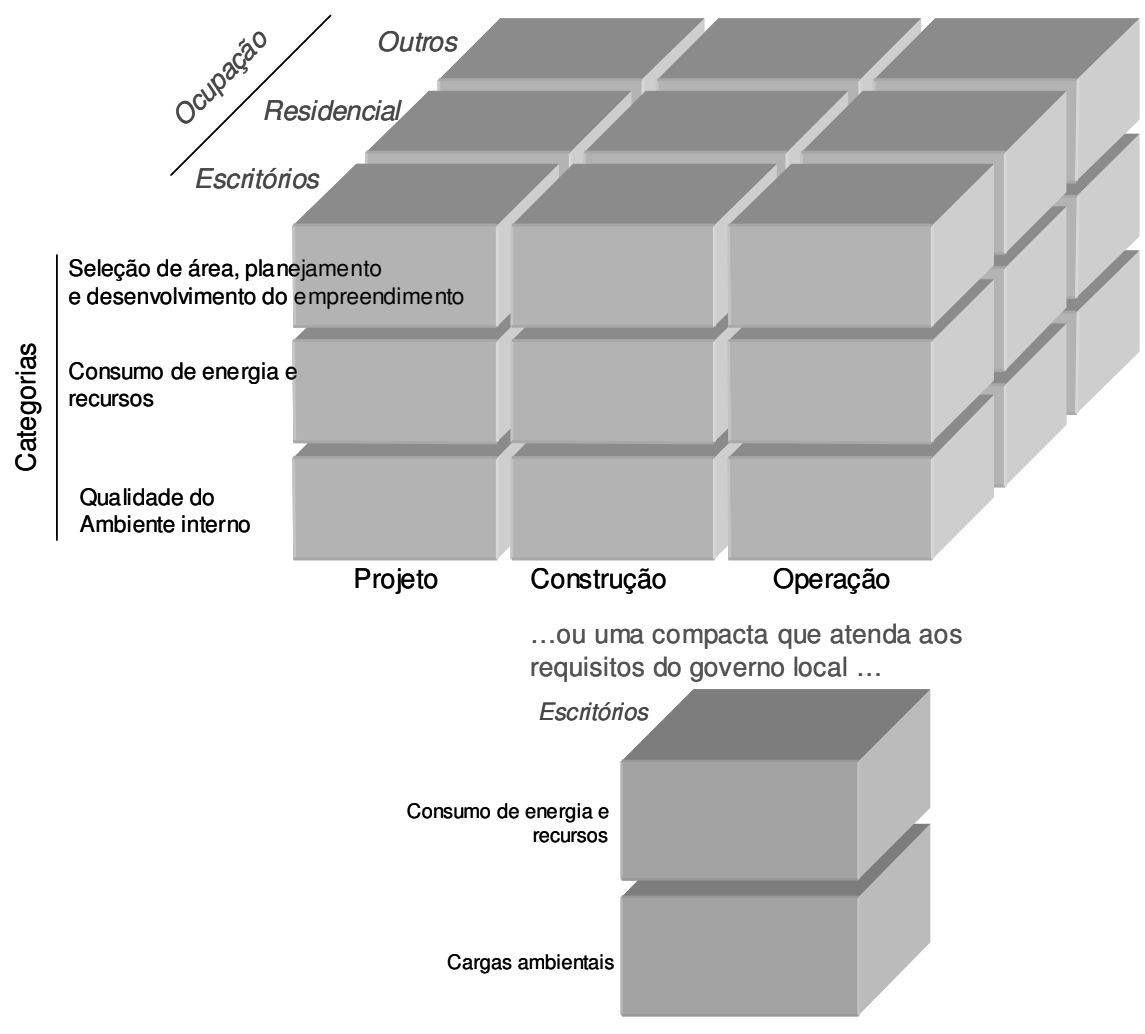

Operação

Figura 2 Esquema do SBTool - fonte: LARSSON, 2007 
A figura 2 demonstra como o método funciona: é possível utilizar toda a estrutura ou apenas o que se deseja avaliar.O sistema cobre uma vasta quantidade de questões de sustentabilidade, que não se restringem somente a indicadores ambientais.

Em sua estrutura, o sistema avalia o empreendimento ou edifício em sete categorias:

- Seleção e escolha do terreno, planejamento do empreendimento e desenvolvimento urbano;

- Consumo de energia e recursos;

- Cargas ambientais;

- Qualidade do ambiente interno;

- Qualidade dos serviços;

- Aspectos econômicos e sociais;

- Aspectos culturais e percepção do usuário.

Dentro de cada uma destas categorias existem sub-categorias que contém os indicadores. Cada um dos indicadores pode ter mais ou menos importância, de acordo com a ponderação escolhida pela autoridades regionais. Existe também a possibilidade de se houver interesse em assim como se não houver dados ou não houver interesse em utilizá-los, estes podem ser "desligados", e a avaliação final só incorpora os indicadores ativos (LARSSON, 2007).

Durante o ano de 2007 e 2008, o sistema passou por inúmeras reformulações e ainda continua em constante evolução. Do modo como está configurado, o sistema pode ser modificado para ser mais restritivo ou mais abrangente dependendo da decisão das autoridades locais em considerar ou não os indicadores.

Atualmente o sistema pode variar de 110 parâmetros para até meia dúzia de indicadores, de acordo com as necessidades locais. Também permite que terceiros (organizações governamentais, ou o próprio poder público) estabeleçam pesos nos parâmetros que reflitam a importância das variações das questões regionais, e também permite estabelecer os padrões relevantes pelo tipo de ocupação em linguagem local. Desta maneira, muitos métodos de avaliação 
podem ser desenvolvidos em diferentes regiões que são relativamente diferentes, mas que compartilham uma mesma estrutura de metodologia e escolha de termos comuns (LARSSON, 2007).

O sistema também tem capacidade para suportar avaliações para os outros quatro estágios do ciclo de vida: da fase de pré-projeto à fase de uso e operação do empreendimento e fornece padrões específicos para se encaixar em cada fase.

Organizações locais podem selecionar até três tipos de edifícios num total de 18 tipos diferentes e avaliá-los separadamente ou como um empreendimento de uso misto.

O sistema lida com grandes projetos ou edifícios únicos, residenciais ou comerciais, novos e existentes ou uma mistura dos dois. Projetistas podem especificar os níveis de desempenho e podem auto-avaliar seu próprio desempenho.

No caso do SBTool, os certificadores responsáveis (no país onde o sistema está implantado) podem aceitar a auto-avaliação submetida pelos projetistas ou podem modificá-las.

A última versão do sistema SBTool está dividida em três grupos de arquivos de planilhas do programa Excel:

- SBT07-A é usado pelas autoridades locais para estabelecer escopo, provável ocupação, tipo, e validar localmente os pesos, padrões e escopo;

- SBT07-B permite que projetistas forneçam a informação sobre o terreno e as características do projeto;

- SBT07-C é usado para a introdução de dados para a auto-avaliação que está baseada nos dados inseridos nos arquivos $A$ e $B$.

Os parâmetros incluídos dentro do sistema cobrem questões de sustentabilidade do edifício dentro de três maiores áreas do ambiente natural, social e econômico.

Uma característica distinta do SBTool é que ele é projetado como um estrutura genérica, e requer um terceira parte para ajustá-lo e encaixá-lo nas condições únicas aplicáveis a certos tipo de edifício em várias regiões. Isto 
significa que uma avaliação usando o sistema tem pequena validade a não ser que a calibração seja feita. A terceira parte deve ajustar os pesos, padrões e emissões de valores através do sistema (LARSSON, 2007).

Os pesos devem ser estabelecidos pela identificação forte, moderada ou fraca entre os critérios do SBTool e um grupo de questões de sustentabilidade. Estas ligações são então ponderadas de acordo com a importância da questão sustentabilidade regional. Todos os números, valores e pesos são ajustáveis pela terceira parte.

O sistema lida com benchmarks ${ }^{6}$, isto é, é estipulado um padrão de desempenho mínimo e a avaliação é feita com base nesta referência.

Benchmark no SBTool são de dois tipos básicos: aquela que podem ser expressas em valores numéricos e aquelas que são melhor descritas em forma de texto. O sistema SBTool tenta expressar tantos parâmetros quantos possíveis em uma forma numérica, mas em alguns casos isto poderia fornecer resultados forjados por isso usa-se também os parâmetros em forma de texto. Em todos os casos, valores de desempenho são relacionados a uma escala que varia de -1 a +5 , com interpretação como se segue:

-1 Negativo

0 Mínimo desempenho aceitável (benchmark, ou valor de referência)

+3 Boa prática

+5 Melhor prática

Naturalmente, os níveis de desempenho relacionados a cada pontuação variam de acordo com a localização e muitas vezes pelo tipo do edifício, que é o motivo pelo qual o SBTool requer terceiras partes locais para definir os níveis de desempenho apropriados. No caso de parâmetros numéricos, estes são feitos pela seleção de dois valores numéricos nos níveis 0 e no +5 , que definem a inclinação da curva para os níveis -1 e +3

\footnotetext{
${ }^{6}$ Benchmark - o termo é definido por Silva (2003) como "desempenho de referência"
} 
3.2.6. Sustainable Building Assessment Tool - SBAT

O SBAT foi desenvolvido em 1999 pela África do Sul e configurou um dos primeiros métodos a considerar os aspectos sociais e econômicos dentro de uma metodologia de avaliação. A idéia inicial e abordagem foram desenvolvidas como parte de um projeto piloto universitário. O método, no entanto, foi evoluindo conforme seu uso numa série de diferentes projetos incluindo edifícios de lazer, de educação, residenciais e comerciais (GIBBERD, 2003).

Ele é apropriado para ser usado no estágio de projeto do empreendimento ou na reforma de edifícios existentes. Pode ser usado como:

- Orientação no processo de projeto das equipes projetistas

- Uma forma de assegurar e verificar que políticas em sustentabilidade estão sendo implementadas e integradas no ambiente construído tanto pelo governo como pelas organizações

O método é projetado para ser facilmente usado e gerar relatórios gráficos para que os resultados de desempenho sejam facilmente lidos. O SBAT pode ser usado numa série de maneiras dependendo do nível de detalhamento exigido. Pode ser usado como uma ferramenta de projeto através do seu lista de verificação, ou ainda como diretrizes e critérios para avaliar a sustentabilidade em edifícios. É possível também para fazer um breve perfil da avaliação do desempenho do edifício e fornecendo uma estrutura mais detalhada de análise do edifício se isto for necessário.

O objetivo do método é dar uma indicação do desempenho do empreendimento ou do projeto do edifício em termos de sustentabilidade. Gibberd (2003) ainda assinala que o método pode ser usado num edifício que acabou de ser finalizado como também pode ser usado em outras etapas do ciclo de vida do empreendimento apesar de alguns critérios não serem relevantes neste caso. A maioria dos tipos de edifícios, como escolas, habitações, escritórios, podem ser avaliados pelo SBAT.

O SBAT divide suas categorias entre as três grandes áreas do 
desenvolvimento sustentável: meio ambiente, aspectos sociais e econômicos. O seu principal diferencial foi justamente incluir os aspectos sociais e econômicos num método de avaliação quando no final da década de 90, métodos como BREEAM, LEED e GBTool só incluíam aspectos ambientais como emissões, impactos no meio ambiente, uso de recursos naturais etc. Hoje em dia quase dez anos depois do desenvolvimento destes métodos, os países desenvolvidos perceberam que os aspectos sociais e econômicos também precisavam ser incluídos e por este motivo muitos métodos que carregavam Green no nome mudaram para Sustainable, como foi apresentado no SBTool.

No caso do SBAT, a avaliação é dividida entre os três principais aspectos: meio ambiente, social e econômico, cada uma destas áreas possui 5 categorias e cada uma destas categorias possui 5 indicadores, totalizando 25 indicadores para cada área e 75 indicadores para o método completo.

O processo de avaliação é dividido entre quatro etapas. Na primeira etapa é estabelecido o objetivo que se quer atingir com a avaliação. Na segunda, as informações sobre o empreendimento, como localização, área etc, são inseridas num arquivo de Power Point. Na terceira etapa passa-se à avaliação propriamente dita e as informações são inseridas em planilhas do programa Excel em forma de porcentagem. Se não há informação a respeito do critério ele é igual a 0\%. Os pesos já são pré-estabecidos e não é possível alterá-los. A última etapa corresponde a um gráfico que apresenta o desempenho do empreendimento em relação ao objetivo estabelecido e o seu desempenho em cada uma das categorias, ao final é dado um resultado indicando o desempenho global do empreendimento.

3.2.7. Leadership in Energy and Environmental Design - LEED

O LEED foi desenvolvido nos Estados Unidos e lançado em 1996, 
representando os esforços do United States Green Building Council, - USGBC ${ }^{7}$ em desenvolver um sistema de certificação para o que se denominou de Green Building - edifício "verde", ou ecológico - termo mais usado para designar produtos ambientalmente corretos.

Ele funciona tanto como um sistema de certificação (ou labelling system) como um guia de projeto para novas construções ou para reformas mais estruturais. O seu lista de verificação orienta os projetistas a reduzir os impactos ambientais através da suas categorias que podem variar de acordo com a versão utilizada (UDALL \& SCHENDLER, 2005). Normalmente são seis: escolha do terreno, qualidade do ambiente interno, materiais, uso eficiente da água, uso eficiente da energia, inovação de projeto ou tecnologia.

O mérito do USGBC, assim como o das outras instituições que desenvolvem os métodos de avaliação é que, a partir do desenvolvimento do método é possível criar um padrão para instituir o que é uma construção com um bom desempenho ambiental e o que não é. No caso dos Estados Unidos, o mercado estava um pouco desorientado, pois qualquer medida tomada poderia ser classificada como uma boa solução ecológica, uma vez que não existiam padrões definidos (UDALL \& SCHENDLER, 2005).

O sistema de avaliação foi primeiramente desenvolvido para construções novas. No entanto foi evoluindo conforme a demanda, e novas versões foram desenvolvidas para atender a outros tipos de construção, algumas ainda estão em fase de teste:

- LEED- NC (New Comercial Construction) - para edificios novos e grandes reformas,

- LEED-EB (Existing Building operations)- para operação e manutenção dos edifícios existentes,

- LEED-CI (Commercial Interiors projects) - para interiores comerciais

- LEED-CS (Core and Shell projects)- para estruturas e coberturas

- LEED-H (Homes) - para casas;

${ }^{7}$ uma associação composta por arquitetos, engenheiros, construtores, projetistas, incorporadores e grupos ligados ao meio ambiente 
- LEED-ND (Neighborhood Developments) - para bairros/ vizinhanças (fase de estudo até 2/2007- Versão piloto a partir de março).

- LEED for Schools - para escolas

- LEED for Retail - para pequenas lojas

Dentre as versões do método, o LEED-ND foi escolhido para avaliação dos conjuntos. O principal foco da avaliação do LEED-ND é a utilização de indicadores para avaliação de áreas urbanas ou vizinhanças/bairros como foi definido no capítulo 2.

Para o desenvolvimento de um método de avaliação de sustentabilidade de áreas urbanas, o Congress for the New Urbanism e o Natural Resources Defense Council e o United States Green Building Council se associaram e elaboraram uma versão do sistema LEED para vizinhanças e bairros: o Leadership in Energy and Environmental Design for Neighborhood Development - LEED - ND.

O objetivo desta parceria é desenvolver um conjunto de padrões para áreas urbanas baseados nos princípios de Smart Growth - Crescimento Inteligente, New Urbanism - Urbanismo Novo e Green Building - Edifício Verde. Diferentemente dos outros produtos do LEED cujo principal foco são as práticas ambientalmente corretas para a construção, o LEED-ND dá ênfase ao projeto e à construção de elementos que combinem os edifícios numa vizinhança e relacione esta vizinhança com a região e a paisagem na qual está inserida.

Os princípios de Smarth Growth e New Urbanism foram definidos no capítulo 2, diversos indicadores presentes no Smart Growth Index, como por exemplo, o street network, que mede a extensão das vias em milhas lineares por milha quadrada de área do empreendimento (miles/square miles), a densidade de unidades habitacionais por milha quadrada ou ainda a freqüência e quantidade de transporte público a meia milha do empreendimento foram inseridos no LEED-ND para que o desenho urbano fosse avaliado.

Quanto aos princípios de Green Building, o LEED-ND incorporou indicadores que os outros métodos estudados também se apropriaram, e que são comuns a todos que se propõem a avaliar uma construção sustentável. 
Dentro destes princípios é possível enumerar alguns como:

- Baixo impacto na vizinhança onde será implantado;

- Localização dentro da infra-estrutura urbana, preenchendo vazios urbanos ou recuperando áreas contaminadas;

- Preferência ao uso do transporte público e do transporte limpo;

- Presença de áreas permeáveis;

- Paisagismo

- Uso eficiente da água, aproveitando a água da chuva e tratando a água usada no empreendimento;

- Uso eficiente da energia;

- Plano de gerenciamento de resíduos durante a construção e depois, durante a operação.

- Monitoramento do conforto e da qualidade dos ambientes internos;

- Quando possível monitoramento das emissões de gases de efeito estufa. Entre outros.

A Environment Ptrotection Agency - EPA define Green Building como construções que são projetadas para trazer benefícios ambientais através do uso eficiente dos recursos naturais, do uso eficiente da água e da energia e da diminuição dos resíduos gerados durante a sua construção e durante a sua fase de operação.

O Green Building ainda deve proporcionar uma boa qualidade do ambiente interno para seus usuários, melhorando o entorno urbano em que está inserido tanto nos aspectos sociais como nos ambientais.

Não há desenvolvimento sustentável sem uma construção civil comprometida com um desenvolvimento econômico baseado na preservação e melhoria do meio ambiente e numa sociedade mais justa e socialmente igualitária (SILVA, 2003).

Esta versão do sistema cria uma etiqueta assim como diretrizes de projeto para o processo de decisão durante sua fase de execução para servir como um incentivo para melhores localizações, projeto e construção dos novos empreendimentos, residenciais, comerciais ou de uso misto. 
Ela funciona também como um incentivo para encorajar a revitalização de áreas urbanizadas, reduzir a extensão do uso do solo, a dependência do automóvel, promover atividades para pedestres, melhorar a qualidade do ar, reduzir a poluição dos cursos de água existentes, contribuir para edifícios mais confortáveis e para que a construção de novos empreendimentos residenciais, comerciais e de uso misto contribuam para o bem-estar da comunidade.

Não existe por enquanto nenhuma restrição quanto ao tamanho do empreendimento. Para aspectos mais qualitativos, não foram definidas as características do termo Neighborhood, como extensão, densidade ou tamanho, no entanto as diretrizes do Smart Growth, New Urbanism e Green Building devem ser seguidas.

O processo de desenvolvimento do método LEED-ND segue o cronograma abaixo:

- Setembro de 2005, lançamento da primeira versão para discussão;

- Fevereiro de 2007, lançamento da versão piloto para teste;

- 2008: Período de comentários e avaliação dos projetos pela versão piloto do LEED-ND

- 2009: Lançamento da versão final do LEED-ND

A versão piloto foi lançada no começo de 2007 e representou uma grande evolução em relação à primeira versão do método. A versão definitiva está prevista para ser lançada em 2009. Atualmente, 238 projetos estão sendo avaliados pela versão piloto, fazendo suas críticas ao método. A grande maioria está localizada nos Estados Unidos, mas projetos de Bahamas, Canadá, China, Coréia e México também participam do Piloto.

O tamanho dos projetos varia de $688 \mathrm{~m} 2$ para o menor até $51.800 .000 \mathrm{~m} 2$ para o maior.

Como são áreas urbanas, vizinhanças e empreendimentos mais complexos que somente edifícios, o Comitê elaborador do LEED entende que o processo construtivo de vizinhanças e áreas urbanas é mais longo, e por isso a certificação demanda mais tempo. Em virtude disto foram estabelecidas para esta versão do LEED três etapas de certificação (USGBC, 2007): 
Etapa 1 - Pré-revisão opcional

Esta etapa é disponível, mas não obrigatória para projetos em qualquer ponto antes do processo de aprovação legal. Se esta pré-revisão é aprovada, o USGBC fornecerá uma carta afirmando que se o projeto for construído como está planejado, então estará apto a receber uma certificação do LEED-ND. O propósito desta carta é dar assistência ao empreendedor junto ao governo ou para conseguir financiamento ou compromisso com os futuros ocupantes.

\section{Etapa 2 - Certificação do plano aprovado}

Esta etapa é disponível depois do projeto ter adquirido todas as aprovações e direitos necessários para construção do projeto. Qualquer mudança no projeto pré-aprovado que possa afetar o alcance de algum pré-requisito ou credito deve ser comunicado ao comitê. Se a certificação for alcançada o USGBC fornecerá um certificado afirmando que o projeto é aprovado pelo LEED - ND e listará no website do USGBC.

Etapa 3 - Certificação completa do desenvolvimento da vizinhança

Esta etapa acontece quando a construção é completa ou quase completa. Se a certificação é adquirida, o USGBC fornecerá uma placa ou um selo similar para ser exibido ao público.

Assim com as outras versões da certificação, o comitê fornecerá uma melhor explicação dos créditos, cálculos e indicadores num guia de referência que será lançado com a versão final do LEED-ND. No caso extremamente necessário, pois esta versão apresenta alguns indicadores bem complexos.

De um modo geral a versão piloto representou realmente uma evolução da versão draft. O sistema ficou bem mais organizado, vários indicadores que não estavam presente antes foram incorporados agora pela versão piloto. Um detalhamento mais profundo será apresentado no capítulo do estudo de caso. 
3.2.8. Alta Qualidade Ambiental - AQUA

O Referencial Técnico de Certificação Edifícios do setor de serviços Processo AQUA Escritórios - Edifícios escolares, de outubro 2007, da Fundação Vanzolini, ou simplesmente AQUA, é o primeiro método brasileiro de certificação ambiental de edifícios a ser lançado para o setor da construção civil. Ele tem como base o método francês NF Bâtiments Tertiaires - Démarche $H Q E^{\circledR}$, em particular o documento técnico Référentiel Technique de Certification "Bâtiments Tertiaires Démarche $H Q E^{\Theta}$. Este foi adequado para a realidade brasileira pela Fundação Vanzolini, a partir de um acordo com o Centre Scientifique et Technique du Bâtiment - CSTB, instituição líder na França na área pesquisa e desenvolvimento, e com sua filial Certivéa, detentoras da certificação.

O referencial francês resultou de um amplo processo de busca de consenso do setor naquele país, envolvendo agentes públicos e privados. Ele iniciou-se no começo dos anos 90, sob a supervisão do Plan Construction Architecture - PCA, atualmente Plan Urbanisme Construction Architecture - PUCA, iniciativa interministerial para a promoção da inovação na área do ambiente construído, com os trabalhos do Atelier d'Evaluation de la Qualité Environnementale - ATEQUE e de uma dúzia de realizações experimentais no domínio da habitação social. A Association $H Q E^{\circledR}$, associação voltada à promoção da sustentabilidade da construção, e da qual a Agence de l'Environnement et de la Maîtrise de l'Energie $A D E M E^{8}$ é membro fundador, capitalizou estas experiências e mobilizou progressivamente os atores da construção civil na França para a produção de documentos consensuais (ADEME, 2006). Dos grupos de trabalhos constituídos resultaram dois documentos: o referencial Définition explicite de la qualité environnementale. Référentiels des caractéristiques HQE (ASSOCIATION, 2001a), que estabeleceu as categorias de preocupações ambientais e de

\footnotetext{
${ }^{8}$ Agência do Meio Ambiente e do Controle da Energia - Para esclarecer de uma forma sucinta, entre outras atividades, a ADEME pode ser definida como o órgão responsável pelo meio ambiente e pela política energética na França.
} 
qualidade do ambiente interno a serem avaliados e as desmembrou em requisitos, indicadores e critérios; e o Référentiel du système de management environnemental pour le maître d'ouvrage concernant des opérations de construction, adaptation ou gestion des bâtiments (ASSOCIATION, 2001b), que estabeleceu os requisitos do sistema de gestão que o empreendedor deve implementar para assegurar a qualidade ambiental final de sua construção.

Num segundo momento, já em 2002, o CSTB, num acordo com a Association $H Q E^{\circledR}$, tomou como base tais documentos, transformando-os numa certificação. Mais uma vez o processo envolveu a criação de grupos de trabalho e a validação dos resultados pelos agentes do setor. Além disso, o método foi testado experimentalmente em 20 empreendimentos selecionados por edital público e parcialmente patrocinados pela ADEME, ao longo de 2003 e 2004, para somente então se transformar numa norma francesa (CARDOSO; DEGANI, 2004).

A metodologia de avaliação francesa foi desenvolvida com o objetivo de limitar os impactos da construção de um edifício novo ou da reabilitação de algum edifício existente tanto sobre o meio ambiente como sobre a qualidade do ambiente interno para os usuários (conforto e saúde). É uma metodologia completamente voluntária de integração dos atores do ambiente construído ao meio ambiente.

A qualidade de vida aparece como um dos objetivos, mas não é o único. $A$ metodologia também visa uma integração do edifico à paisagem, à estrutura e serviços urbanos existentes, à redução do consumo dos recursos naturais e das emissões e conseqüentemente de um menor custo durante a operação do edifício. Ou seja, é uma metodologia de avaliação que tem como objetivo alinhar a construção civil com os princípios do desenvolvimento sustentável.

Assim como o francês, o referencial técnico brasileiro é estruturado em duas partes que avalia o empreendimento de maneiras complementares (Vanzolini, 2007):

A primeira compreende o Sistema de Gestão do Empreendimento que trata da gestão a ser estabelecida pelo empreendedor para assegurar a qualidade ambiental final de sua construção. 
A segunda corresponde à Qualidade Ambiental do Edifício, que avalia o desempenho do empreendimento de acordo com suas características técnicas e arquitetônicas.

O empreendimento também é avaliado em três momentos: na fase de préprojeto (programa de necessidades), na fase de concepção e ao final da execução da obra, para a certificação final.

Para avaliar a Qualidade Ambiental do Edifício, o referencial estrutura-se em 14 categorias, propostas no documento original francês pelos trabalhos da Association $H Q E^{\circledR}$, como mostra a tabela 1.

Tabela 5 Esquema de organização das categorias do método AQUA (Vanzolini, 2007).

Domínio 1: Categorias de controle sobre o meio
ambiente Exterior

Eco-construção

1) Relação do edifício com seu entorno

2) Escolha integrada de produtos, sistemas e processos construtivos

3) Canteiro de obras com baixo impacto ambiental

Gestão

4) Gestão da energia

5) Gestão da água

6) Gestão dos resíduos de uso e operação do edifício

7) Gestão da manutenção - Permanência do desempenho ambiental
Domínio 2: Categorias para a criação de um bom ambiente interno

Conforto

8) Conforto higrotérmico

9) Conforto acústico

10) Conforto visual

11) Conforto olfativo

Saúde

12) Condições sanitárias dos ambientes

13) Qualidade do ar

14) Qualidade da água

Cada categoria contém subcategorias que são constituídas de preocupações ambientais. Uma importante fase da metodologia é uma hierarquização das exigências ambientais, que deve ser efetuada pelo empreendedor ou responsável pelo empreendimento. Uma lista de prioridades deve ser estabelecida e o desempenho do empreendimento é avaliado sob três níveis, conforme a figura 3. 


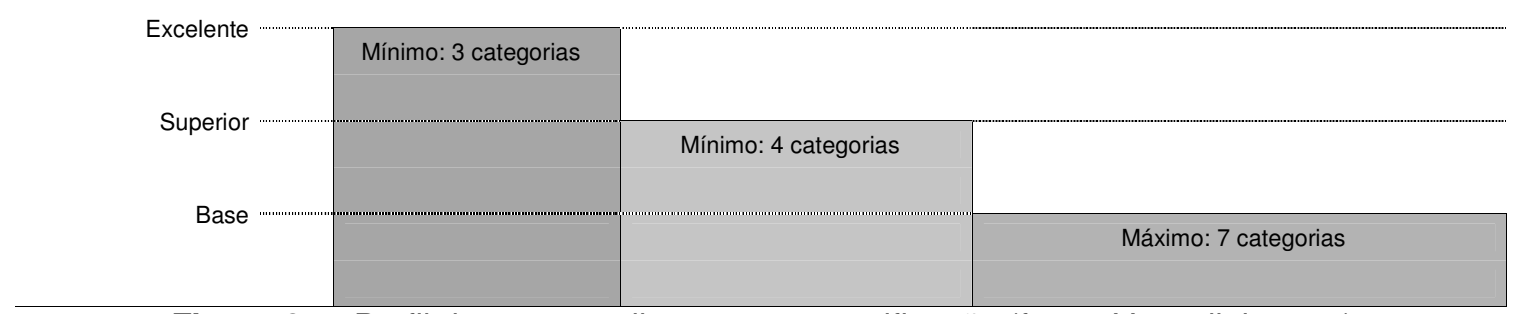

Figura 3 Perfil do empreendimento para certificação (fonte: Vanzolini, 2007)

A figura 1 mostra que, entre as 14 categorias do método, é necessário escolher no mínimo 3, que o processo de avaliação implementado pelo empreendedor aponta como as mais importantes, para atingirem o nível Excelente (nível de desempenho mais alto). Das outras 11 restantes, 4 devem atender 0 nível Superior (nível intermediário) e as outras sete deverão ser tratadas de acordo com a legislação vigente ou com as práticas correntes

A escolha de quais categorias devem ter um desempenho superior se faz em função do terreno em que será implantada a construção, da finalidade do empreendimento, de todas as características próprias ao projeto e dos interesses das diversas partes interessadas, incluindo do próprio empreendedor (VANZOLINI, 2007). Nesse sentido, os empreendimentos certificados diferem entre si, pois as prioridades assumidas para cada um são diferentes, cada um tendo o seu próprio "perfil de qualidade ambiental".

Sintetizando, para conseguir a certificação, o empreendimento precisa ter no mínimo três categorias com desempenho Excelente, outras quatro categorias com desempenho Superior e o restante com um desempenho Base. Esta é a configuração mínima para se conseguir a certificação, que não contém níveis de classificação como no BREEAM ou no LEED. Por exemplo, se um empreendimento conseguir um desempenho Excelente em sete categorias ele não é premiado por isso. Esta é uma das críticas ao método quando comparado aos outros.

Por outro lado, Cardoso (2002) afirma que isto é um diferencial da certificação em relação às outras. Pois o empreendimento não pode apresentar 
nenhuma das sete categorias restantes abaixo do nível Base. O nível Base corresponde à legislação vigente ou às práticas correntes referentes a uma determinada questão como uso eficiente da água, energia etc. Além, assegura-se a aderência entre o "perfil" do empreendimento e as características desejáveis para ele e que lhe agregam de fato valor.

Outra diferença com relação a outros metodos é que, em muitas categorias, ela não prescreve os indicadores que precisam ser alcançados.

Por exemplo, a categoria 1 - Relação do edifício com seu entorno tem três subcategorias e cada uma delas tem um número de itens. Existem exemplos sobre como atender estes itens, mas o sistema apenas orienta como eles podem ser atendidos e o que é considerado ou não para seu completo atendimento. Para se alcançar o nível básico, é preciso atender três destas cinco preocupações; para se atender o nível intermediário, é necessário quatro das cinco e; para se atender o nível superior é necessário atender todas. A partir disto a subcategoria atinge 0 nível visado.

Por sua vez, o nível da categoria é dado pela combinação dos níveis alcançados nas subcategorias. Este item será mais detalhado no capítulo 5 sobre o estudo de caso.

Apesar do referencial ser direcionado a edifícios de escritórios e edifícios escolares, a categoria 1 - Relação do edifício com seu entorno foi escolhida para avaliar os conjuntos habitacionais porque ela tem uma estrutura mais genérica e principalmente para saber como o referencial técnico funciona, no que concerne à qualidade ambiental do edifício. 


\section{O CONTEXTO DOS PAÍSES EM DESENVOLVIMENTO}

De acordo com as estimativas de Angel et al. (2005) a população das cidades dos países em desenvolvimento irá dobrar nos próximos trinta anos; e a área territorial das cidades será triplicada, isto quer dizer que por volta de 2030, cada novo habitante de uma cidade transformará cerca de $160 \mathrm{~m} 2$ em área urbana. Como o espaço urbano será organizado, como serão tratadas as questões relacionadas a transporte e infra-estrutura que já são problemáticas?

Angel et al (2005) alerta para o fato de que os países em desenvolvimento possuem uma realidade diferenciada e que a questão da expansão urbana deveria receber mais atenção.

Países em desenvolvimento apresentam uma realidade diferenciada, em que as questões sociais e econômicas têm uma relevância maior que nos países desenvolvidos, dessa maneira, diretrizes e políticas nacionais devem ser orientadas para suprir esta deficiência.

Gibberd (2001) enfatiza que o padrão de vida dos países em desenvolvimento muitas vezes não atende nem as necessidades básicas do indivíduo como a habitação digna e saúde, por exemplo.

No caso de São Paulo e de outras grandes cidades brasileiras, existe uma cidade informal - constituída por favelas, ocupações irregulares, que co-existe com a cidade formal. Nesta cidade informal, as condições são extremamente precárias em termos de qualidade de vida e impacto ambiental, uma vez que esgoto e lixo doméstico são despejados diretamente em córregos e/ou terrenos vazios.

$\mathrm{Na}$ África do Sul, uma série de iniciativas e políticas foram introduzidas pelo governo no sentido de melhorar as condições de vida da população: Estratégia de Desenvolvimento Sustentável Rural Integrado, Relatório de Meio Ambiente, Estratégia Industrial Integrada para Crescimento, entre outros.

No Brasil, Fossati (2008) destaca as ações tomadas pelo país na busca pelo alinhamento com o desenvolvimento sustentável, em termos ambientais a 
autora cita a Resolução 307/02 do CONAMA, que trata da gestão dos resíduos da construção civil, e também a Lei 10.295 que estabelece as diretrizes para o uso eficiente da energia após a crise energética de 2001.

No campo acadêmico, inúmeras iniciativas vêm sendo tomadas pelas universidades do país inteiro que abordam os princípios de desenvolvimento sustentável em todas as áreas da construção civil e do urbanismo. (para conhecimento e aprofundamento destas pesquisas ver: SEDREZ, 2004; SILVA, 2003; CARLO, 2008; para citar alguns trabalhos.

Há, ainda, o Projeto Tecnologias para uma Habitação mais Sustentável, financiado pela FINEP, composto por cinco universidades para propor uma metodologia de avaliação de sustentabilidade para conjuntos habitacionais e a autoconstrução. O website http://www.habitacaosustentavel.pcc.usp.br divulga o conteúdo desenvolvido.

Em agosto de 2007 foi criado o Conselho Brasileiro de Construção Sustentável - $\mathrm{CBCS}^{9}$, formado tanto por integrantes do mercado como da academia e que visa promover a construção sustentável por meio da disseminação do conhecimento.

No plano da construção civil, o mercado brasileiro vem apresentando uma demanda por certificação de sustentabilidade das construções que não existia antes.

No final de 2007, foi lançado o método nacional Alta Qualidade Ambiental AQUA, proveniente de uma adaptação da metodologia francesa: Norme Française Bâtiments Terciaires - Haute Qualité Environnementale. A certificação é fornecida pela Fundação Carlos Alberto Vanzolini e, atualmente alguns projetos estão manifestando o interesse pela certificação.

Como o lançamento do AQUA só ocorreu no final de 2007, a ausência de um método nacional de avaliação durante tanto tempo acarretou na adoção do

\footnotetext{
${ }^{9}$ O Conselho Brasileiro de Construção Sustentável é uma Organização da sociedade Civil que foi fundada agosto em 2007 com o objetivo de "promover a melhoria da qualidade de vida da população brasileira e a preservação de seu patrimônio natural, pelo desenvolvimento e implementação de conceitos e práticas mais sustentáveis e que contemplem as dimensões social, econômica e ambiental da cadeia produtiva da indústria da construção civil,". O Conselho conta com a presença de lideranças empresairiais, pesquisadores, consultores, profissionais atuantes e formadores de opinião. www.cbcs.org.br
} 
método americano LEED, como a referência do que é uma construção sustentável, apesar de ser inteiramente voltado à realidade dos Estados Unidos onde foi desenvolvido.

Foi também criado o Green Building Council Brasil - o GBC Brasil (alinhado com o WGBC - World Green Building Council) para divulgar a certificação LEED aqui no Brasil. Atualmente existem 23 organizações brasileiras credenciadas como membros do USGBC, 25 profissionais credenciados e 34 projetos cadastrados para certificação de acordo com o site: http://www.usgbc.org/myUSGBC.

Atualmente quatro edificações já foram certificadas: Banco Real Agência Bancária Granja Viana em Cotia, e o Delboni Auriemo - Dumont Villares, no Município de São Paulo, o Banco J.P.Morgan também em São Paulo e o edifício da Bracor no Rio de Janeiro.

No setor habitacional, nos últimos anos, a Companhia de Desenvolvimento Habitacional e Urbano do Estado de São Paulo - CDHU tem adotado algumas medidas no que dizem respeito à melhoria das condições da habitação de interesse social. Para melhora da qualidade e unificação do processo de projeto, a empresa desenvolveu um manual técnico de projetos. Ela também investiu no sentido de implementar alguns conceitos de desenvolvimento sustentável dentro dos seus projetos.

Um grande desafio ao alcance do desenvolvimento sustentável é a questão habitacional brasileira. No Brasil, há diversos programas para atender à demanda por unidades habitacionais da classe de baixa renda, mas ainda se registra um déficit que pode ser classificado em dois tipos: o déficit quantitativo, que seria a quantidade de unidades que precisa ser construída para atender à demanda demográfica; e o outro é o "déficit' qualitativo que representa a quantidade de unidades habitacionais consideradas inadequadas pela falta de infra-estrutura, localização precária ou pelo excesso de pessoas (UNEP, 2002).

De uma maneira geral, os conjuntos habitacionais brasileiros não apresentam características relacionadas à preocupação ambiental (FREITAS, 2001).

De acordo com Moretti (1997), a legislação brasileira é extremamente 
restritiva, limitando a utilização de desenhos diferenciados e induzindo à implantação de algumas tipologias de projeto com alto custo de implantação de infra-estrutura, como por exemplo:

- Unidades unifamiliares isoladas no lote;

- Sistema viário em malha, com vias largas com acesso direto às unidades, sem hierarquia de vias;

- Execução de grandes movimentos de terra para adaptar o terreno ao conjunto que muitas vezes é projetado para terrenos praticamente planos.

Freitas (2001) cita a construção do conjunto Santa Etelvina na década de 80 como exemplo dos projetos problemáticos que foram concebidos sem um mínimo de preocupação com as características geológicas do terreno. O conjunto Santa Etelvina está localizado na Zona Leste do Município de São Paulo e foi construído pela Companhia Metropolitana de Habitação do São Paulo - Cohab/SP como um exemplo de um conjunto habitacional extremamente problemático quanto às obras de terraplanagem. De acordo com o autor, o volume de terra movimentado (cerca de $5.000 .000 \mathrm{~m}^{3}$ ) para a construção do conjunto foi equivalente a $21 \%$ do volume necessário para a implantação da Usina Hidrelétrica de Itaipu, uma das maiores do planeta. 


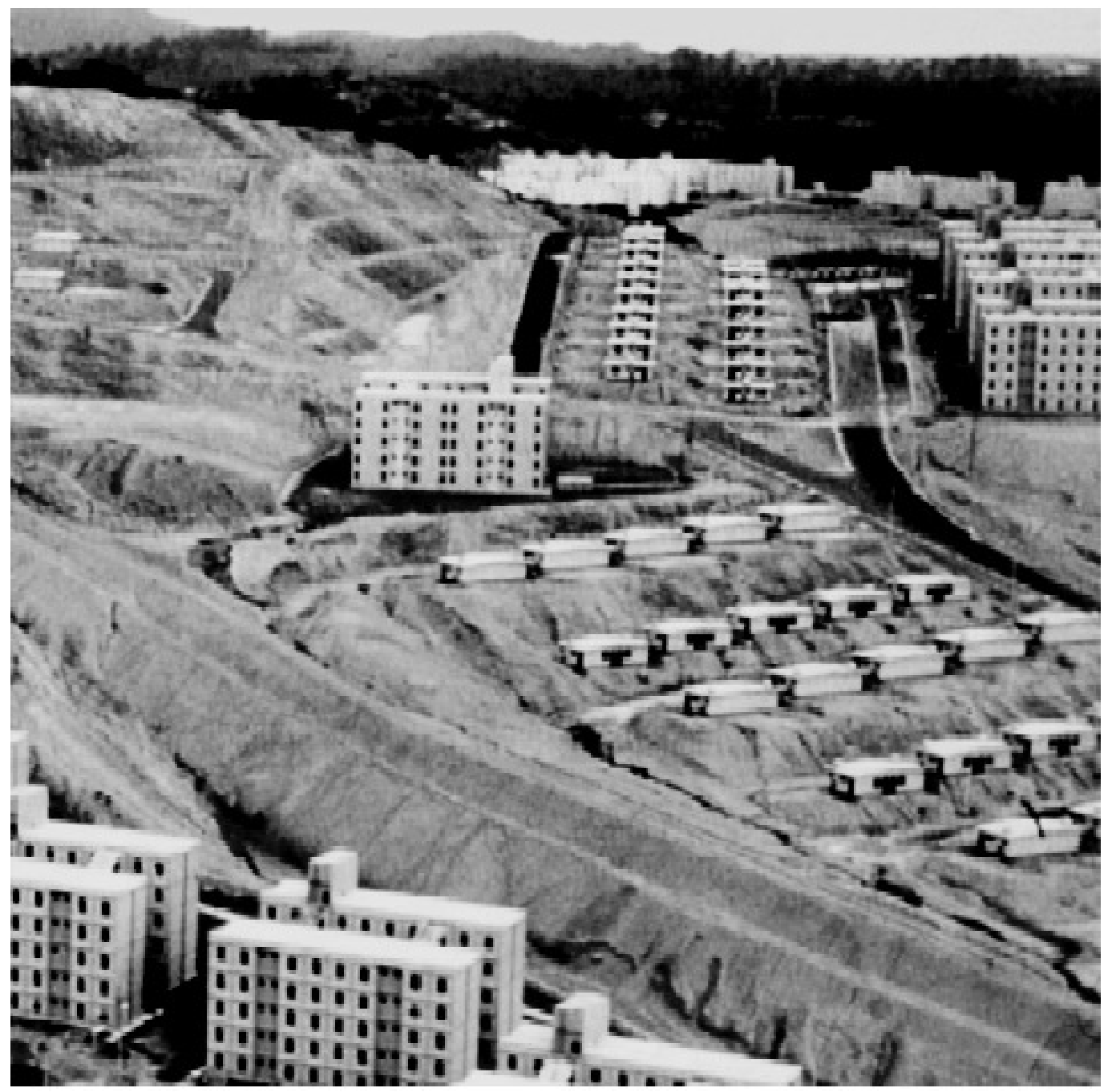

Figura 4 Obras de implantação do conjunto Santa Etelvina - Zona Leste São Paulo Fonte: Freitas, 2001

A figura 4 mostra a implantação do Conjunto Santa Etelvina em 1983. Pode-se perceber a grande movimentação de terra e o solo completamente exposto. O conjunto sofreu muito com falta de estabilização do terreno e com a erosão provocada pelas chuvas. Freitas (2001) ainda afirma que na época da consolidação do empreendimento, o custo de cada uma das 40.000 unidades era equivalente ao valor de mercado de um apartamento na Avenida Paulista, devido às inúmeras obras de recuperação do conjunto que se fizeram necessárias. 0 conjunto configurou o exemplo do que não deve ser feito em conjuntos habitacionais. 
Além da terraplanagem, Moretti (1997) enumera fatores como insolação, impactos na vizinhança, obras de infra-estrutura como alguns dos outros problemas que a legislação restritiva acarreta na implantação dos conjuntos habitacionais.

Em São Paulo, a CDHU possui diversos programas para conseguir atender à demanda e entre eles podem ser citados os programas de urbanização de favelas, as parcerias entre os municípios para a produção de novas unidades habitacionais que são os conjuntos habitacionais de interesse social.

Dentre as inúmeras definições de conjuntos habitacionais existentes, este trabalho adota a mesma definição de Inouye (2003):

\begin{abstract}
Adota-se para este trabalho, o conceito de conjunto habitacional horizontal como sendo o agrupamento de edificações (uni ou multifamiliares) de até dois pavimentos (unidades térreas e/ou sobrados), para uso habitacional, concebido de forma planejada e dotado de infra-estrutura básica
\end{abstract}

Apesar de não configurar uma metodologia de avaliação, a CDHU elaborou um Manual Técnico de Projetos que se baseou numa proposta de implantação de um "Sistema de Qualidade em Projetos Habitacionais"- uma iniciativa que foi coordenada pelo Instituto de Pesquisas Tecnológicas - IPT em 1996.

Para isto uma série de atividades como: cadastramento de fornecedores dos projetos, procedimentos para licitação, contratação e avaliação e controle de qualidade de projetos e aperfeiçoamento dos documentos de referência, foram realizadas com o intuito de se implantar este sistema de qualidade.

Para garantir a qualidade das habitações construídas pela Companhia foi desenvolvido o Programa Qualihab. O programa tem caráter evolutivo a partir de um processo de melhoria contínua do desempenho.

Diversas entidades do setor da construção civil participam do programa cumprindo os requisitos mínimos estabelecidos para garantir a qualidade dos materiais e dos serviços que são utilizados nas construções das unidades habitacionais. Somente os participantes do programa podem ser fornecedores da CDHU e isso inclui as construtoras. Como princípios gerais, o programa tem o objetivo de fornecer uma moradia de qualidade considerando o desempenho ao 
longo de sua vida útil.

Como empresa pública responsável pelo fornecimento de grande parte das habitações de interesse social do Estado de São Paulo, a CDHU adotou diretrizes próprias como um denominador comum entre as várias legislações municipais para o desenvolvimento das habitações de interesse social.

O manual detalha os programas que incluem os projetos de urbanização e os de edificação, além também de incluir a fase de pré-projeto e levantamento de dados do terreno como serviços de geotecnia e topografia.

Para a realização do projeto de urbanismo e para se verificar a adequação e distribuição dos usos, são levantados os custos e perfil social e econômico da demanda, dados do município, as características do terreno e sua localização, infra-estrutura urbana existente etc. Com base nestes dados um relatório é elaborado com a análise de todas as informações para desenvolvimento da tipologia a ser adotada e o uso do solo. O Manual especifica como os documentos devem ser apresentados, os projetos a serem desenvolvidos, mas ainda não possui diretrizes de princípios de desenvolvimento sustentável.

É interessante observar que para elaborar seus projetos o Manual faz um levantamento da área por meio de indicadores para avaliar o potencial do terreno. E estes indicadores são muito semelhantes aos existentes nos sistemas de avaliação de sustentabilidade estudados, a semelhança acontece principalmente na categoria relacionada a seleção de áreas, ou relacionamento do edifício com seu entorno.

Acompanhando o debate internacional que vinha acontecendo no mundo sobre os impactos da construção no meio ambiente, no período de 1998 a 2002, os técnicos da CDHU se organizaram para formar um novo manual que estivesse alinhado com princípios de Ecodesign. O maior desafio a que este novo Manual se dispunha era o de enfrentar e incorporar os princípios de sustentabilidade social e ambiental nos projetos urbanos e habitacionais de interesse social através da visão integrada de produtos e processos e da adoção de princípios e critérios ambientais.

A base para a elaboração do Manual foram os conceitos de 
sustentabilidade, capital natural e ciclo de vida, carga poluidora, produção mais limpa, pegada ecológica, qualidade de vida, entre outros. O objetivo era desenvolver novos modelos de atuação de produção habitacional para conseguir suprir a demanda nacional com a melhor qualidade possível nas três dimensões do desenvolvimento sustentável.

A aplicação destes princípios foi efetivada no desenvolvimento e implementação de um conjunto habitacional em parceria com a prefeitura do município de Atibaia, que é o conjunto Atibaia $D$ e que será detalhado no capítulo 5. 


\section{OS CONJUNTOS HABITACIONAIS SELECIONADOS}

Neste capítulo os conjuntos habitacionais selecionados para o estudo de caso são apresentados, para que assim, no capítulo seguinte seja feita a avaliação pelos métodos com os comentários a respeito dos aspectos mais importantes dessa avaliação.

Os dois conjuntos foram escolhidos por possuírem características semelhantes e dessa maneira apresentarem uma possibilidade de comparação: ambos são conjuntos habitacionais horizontais, possuem até 500 unidades habitacionais, estão localizados na periferia das cidades nas quais estão inseridos.

No entanto, ambos foram produtos de diferentes diretrizes: o Marechal Tito H1 representa uma forma de concepção tradicional de projeto, em que se entregava somente um embrião ao mutuário, que ficava com a responsabilidade de fazer as ampliações necessárias à sua unidade.

O Atibaia D, por outro lado, foi concebido sob uma perspectiva diferenciada, em que diversas diretrizes ambientais foram as norteadoras do projeto. No Atibaia $D$ existe a possibilidade de somente uma das tipologias ser ampliada que é o sobrado. A tabela 6 apresenta uma comparação entre os dois conjuntos referente às áreas: 
Tabela 6 Comparação entre os dois conjuntos selecionados para o estudo de caso

\begin{tabular}{|c|c|c|c|c|}
\hline & \multicolumn{2}{|c|}{ Marechal Tito $\mathrm{H} 1$} & \multicolumn{2}{|l|}{ Atibaia D } \\
\hline Tipo & \multicolumn{2}{|c|}{ Conjunto habitacional horizontal } & \multicolumn{2}{|c|}{ Conjunto habitacional horizontal } \\
\hline No de Uhs & \multicolumn{2}{|c|}{488 Uhs } & \multicolumn{2}{|l|}{369 UHs } \\
\hline Bairro/ cidade & \multicolumn{2}{|c|}{ Itaim Paulista - São Paulo } & \multicolumn{2}{|c|}{ Caetetuba - Atibaia } \\
\hline $\begin{array}{l}\text { Processo } \\
\text { construtivo }\end{array}$ & \multicolumn{2}{|c|}{ Empreitada global } & \multicolumn{2}{|c|}{ Mutirão + empreitada global } \\
\hline \multirow[t]{2}{*}{ Tipologia } & \multicolumn{2}{|c|}{ Casas térreas } & \multicolumn{2}{|c|}{ Casas térreas + sobrado } \\
\hline & Áreas & $\%$ & Áreas & $\%$ \\
\hline Terreno & $109.434 \mathrm{~m} 2$ & 100 & $83.090 \mathrm{~m} 2$ & 100 \\
\hline Lotes: & $58.830 \mathrm{~m} 2$ & 53,75 & $44.251 \mathrm{~m} 2$ & 53,26 \\
\hline Ruas: & $28.043 \mathrm{~m} 2$ & 25,62 & $25.260 \mathrm{~m} 2$ & 30,40 \\
\hline $\begin{array}{l}\text { Sistema de } \\
\text { lazer: }\end{array}$ & $12.656 \mathrm{~m} 2$ & 11,56 & $10.278 \mathrm{~m} 2$ & 12,37 \\
\hline $\begin{array}{l}\text { Equipamentos } \\
\text { comunitários: }\end{array}$ & 9.905 & 9 & $3.299,31$ & 3,97 \\
\hline $\begin{array}{c}\text { Área média do } \\
\text { lote }\end{array}$ & $120 \mathrm{~m} 2$ & & $119 \mathrm{~m} 2$ & \\
\hline $\begin{array}{c}\text { Área construída } \\
\text { de cada UH }\end{array}$ & $24 \mathrm{~m} 2$ & & $\begin{array}{c}55,36 \text { - sobrado } \\
51,17 \text { - casa térrea }\end{array}$ & \\
\hline
\end{tabular}

De acordo com o quadro de áreas, o conjunto Marechal Tito é cerca de $20.000 \mathrm{~m} 2$ maior que o Atibaia $\mathrm{D}$, mas as porcentagens das áreas são semelhantes. Os lote do Marechal Tito são praticamente do mesmo tamanho do Atibaia $\mathrm{D}$ e proporcionalmente, o Atibaia $\mathrm{D}$ tem uma área maior para os sistemas de lazer. No entanto, o Marechal Tito possui uma área maior destinada aos equipamentos comunitários.

A área construída das unidades habitacionais também é diferente: cada unidade do Marechal Tito corresponde a menos que a metade da área das unidades do Atibaia.

O primeiro conjunto a ser apresentado é o Conjunto Marechal Tito. Em seguida é apresentado o Conjunto Atibaia D. 


\subsection{O CONJUNTO HABITACIONAL MARECHAL TITO H1}

De acordo com a Prefeitura do Município de São Paulo o crescimento do Itaim Paulista foi lento, numa área de mata atlântica virgem que era recortada por vários córregos que hoje estão bem poluídos. A região já foi o reduto de olarias que se desenvolveram devido ao crescimento da Cidade, na verdade a região toda era fornecedora de materiais para a construção: alem dos tijolos, também fornecia areia e pedregulho que eram extraídos do Rio Tietê.

No mapa do Município de São Paulo, o Itaim Paulista é o ultimo distrito localizado no campo azul Leste 2. 


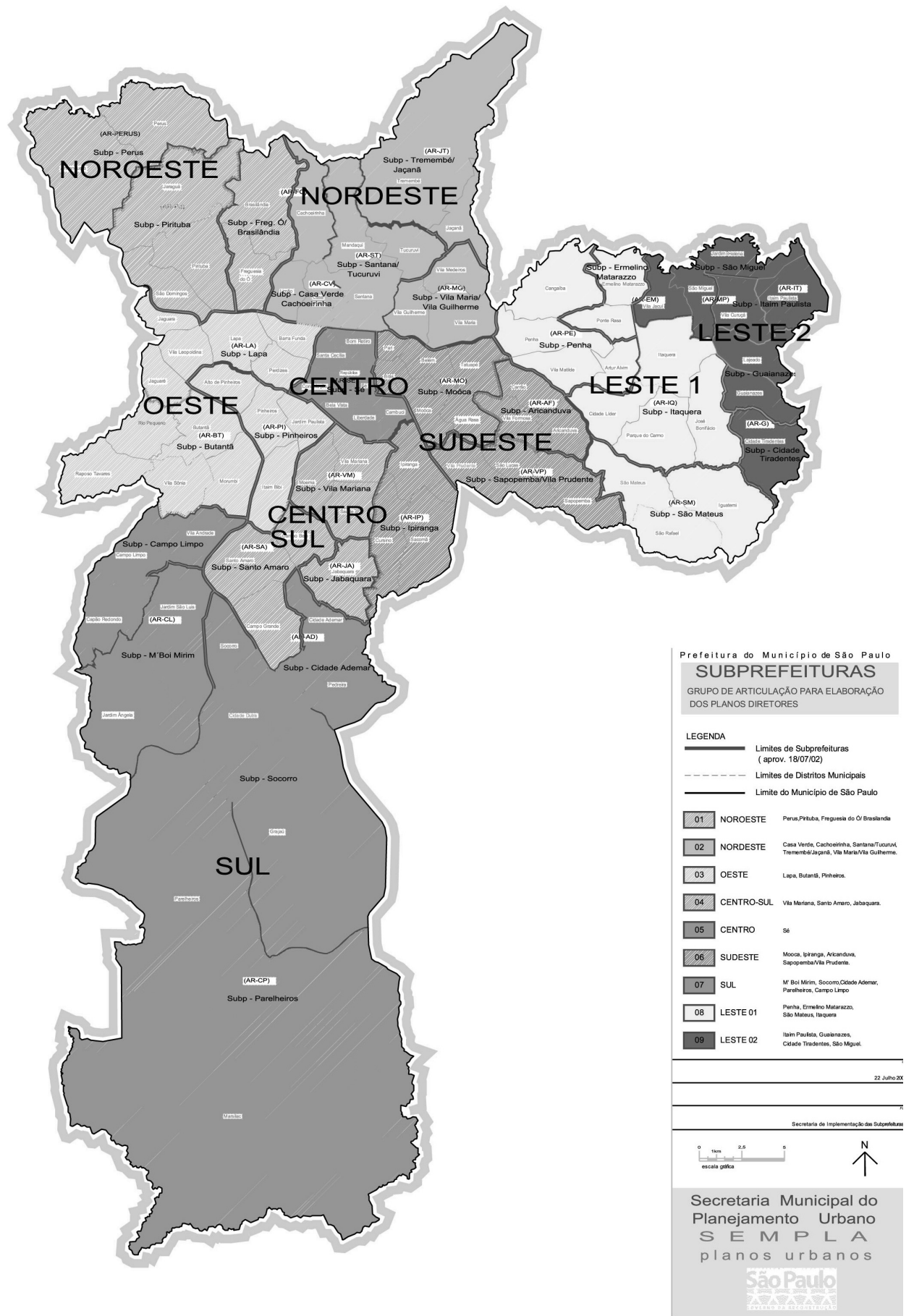

Figura 5 Mapa das Subprefeituras do Município de São Paulo. (fonte: http://ww2.prefeitura.sp.gov.br//arquivos/guia/mapas/0001/mapa_subprefeituras.jpeg)

Nos primeiros séculos de colonização, o Itaim Paulista era um misto de chácaras, fazendas e sítios, que continuavam com esta configuração, desestimulados pela falta de infra-estrutura e sufocados pelo progresso dos vizinhos, o Itaim Paulista só começou a receber seus primeiros moradores no final do século 18. 
A chegada da ferrovia - Estrada do Norte, antiga Central do Brasil iniciou um novo processo de desenvolvimento. A partir de 1950 a região sofreu um forte processo de ocupação, seja regular, irregular ou por motivo dos conjuntos habitacionais que foram ali implantados. Em 1980 a região ganhou autonomia administrativa: desvinculava-se de São Miguel Paulista para constituir primeiramente a Regional do Itaim Paulista de posteriormente a Subprefeitura do Itaim Paulista.

A situação nos dias de hoje está um pouco diferente: as áreas em torno dos córregos foram todas invadidas por moradias irregulares. Os conglomerados de casas humildes que se formaram às margens dos afluentes do Tietê são imensos. A ocupação irregular ainda é freqüente na região devido à desvalorização dos terrenos e à falta de infra-estrutura. Atualmente, de acordo com a SEMPLA são 375.111 habitantes ocupando 2.170 hectares de área.

O projeto do conjunto Marechal Tito H é de 1993. Há cerca de 15 anos atrás a estrutura do Itaim Paulista já era praticamente a mesma da de hoje em dia. No entanto mais invasões foram registradas principalmente nas áreas não ocupadas pelos conjuntos habitacionais ou nas áreas de proteção ambiental como nas margens dos inúmeros córregos existentes.

De acordo com a $\mathrm{CDHU}^{10}$, quando foi realizado o levantamento do entorno do conjunto Marechal Tito na época de seu projeto, a área em que o conjunto seria implantado num terreno inserido numa área urbana já consolidada: com infra-estrutura instalada: água, esgoto, iluminação e serviços. A região serve de ligação entre a Capital e as cidades da Região Metropolitana da zona leste como Poá e Itaquaquecetuba, e a parte sul da zona leste como Guaianazes.

\footnotetext{
${ }^{10}$ Entrevista fornecida por funcionária do departamento de terras da CDHU em abril de 2008
} 


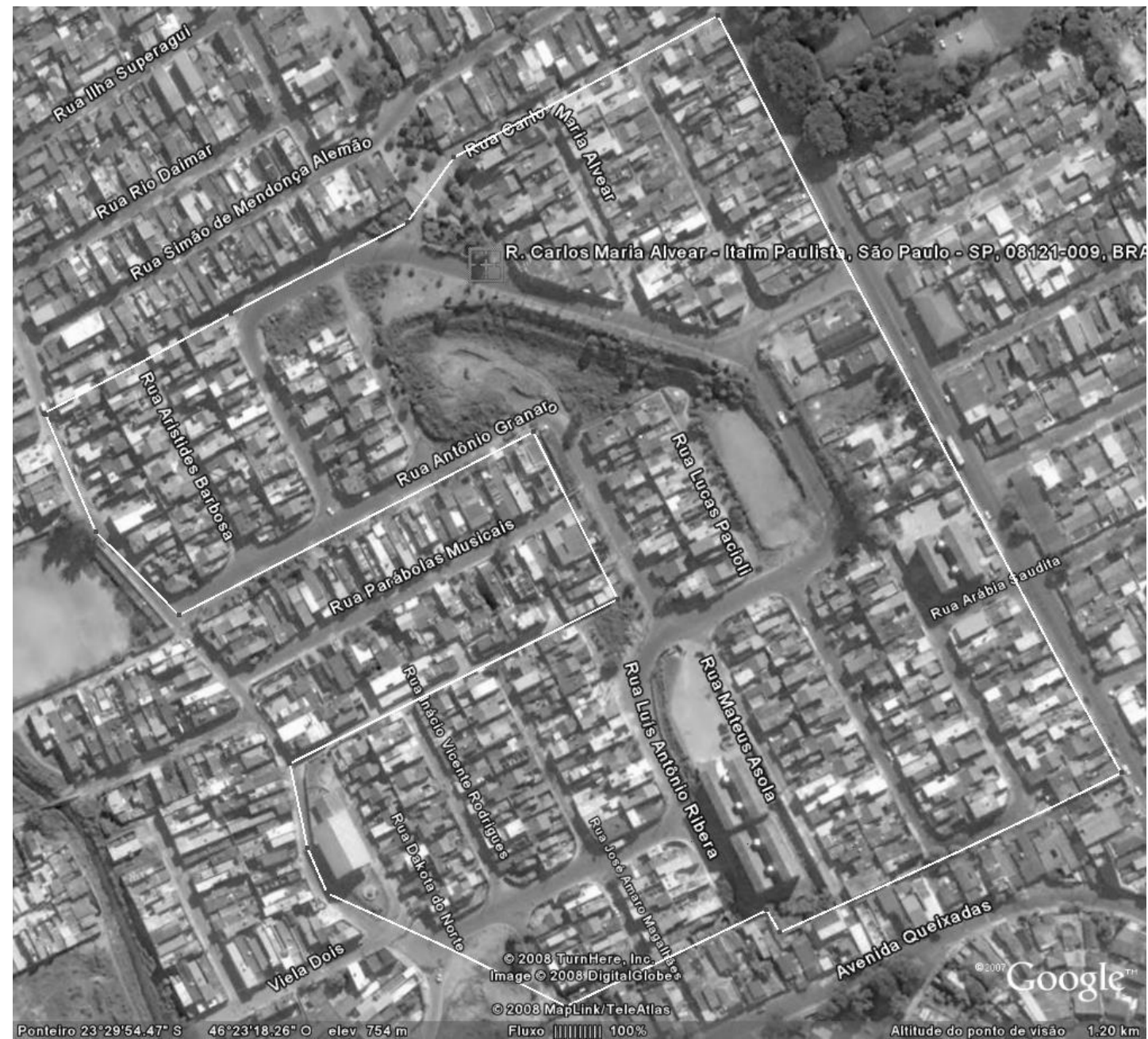

Figura 6 Vista do conjunto em 2008 pelo Google Earth, o limite do conjunto é a linha branca

A figura 6 mostra a implantação do conjunto Marechal Tito H1. O conjunto foi bastante modificado a partir do seu projeto original. É possível perceber a região urbana ao redor do conjunto que está delimitado pela linha branca. Todas as informações levantadas sobre o conjunto estão detalhadas nas tabelas a seguir.

As tabelas 7, 8 e 9 mostram alguns dados e as áreas referentes ao conjunto Marechal Tito. A tabela 6 detalha os códigos censitários que formam o conjunto. Informações como renda, número de domicílios, classificação do setor foram levantados a partir dos dados do IBGE, 2000. 
Tabela 7 Dados do IBGE (2000)

Código do setor censitário

355030836000021

355030836000043

355030836000044

355030836000045

Situação urbana

Tipo de setor

Domicílios particulares permanentes

Área urbanizada de cidade ou vila
Comum

Rendimento mensal médio da população (IBGE, 2000)

$R \$ 482,00$

A tabela 8 apresenta as áreas do empreendimento, e a porcentagem de cada uma das áreas no todo.

Tabela 8 Áreas e porcentagem de ocupação do terreno do Conjunto Marechal Tito

\begin{tabular}{lcl} 
Legenda & Area $\left(\mathrm{m}^{2}\right)$ & $\%$ \\
\hline Terreno & 109434.34 & 100,00 \\
\hline Lotes & 58830.03 & 53,75 \\
\hline Ruas & 28043.55 & 25,62 \\
\hline Sistemas de lazer & 12656.61 & 11,56 \\
\hline Equipamentos Comunitários & 9904.25 & 9 \\
\hline Equipamentos urbanos & - & 0,00 \\
\hline Total & 109434.34 & 100 \\
\hline Edificações & & \\
\hline Sobrado & 24,75 &
\end{tabular}

Fonte: $\mathrm{CDHU}$

A tabela 9 fornece dados sobre a urbanização e a ocupação do terreno pelo conjunto.

Tabela 9 Dados urbanísticos e de ocupação

\begin{tabular}{ll}
\hline Requisitos urbanísticos & \\
\hline $\mathrm{N}$. de habitantes por residencia & 5 \\
\hline população prevista & 2430 \\
\hline inclinação das do terreno das unidades & $5 \%$ \\
\hline Lotes Residenciais & 488 \\
\hline Testada média & 5 ou $3,30 \mathrm{~m}$ \\
\hline profundidade média & $18 \mathrm{~m}$ \\
\hline área média & $220 \mathrm{~m} 2$ \\
\hline Fonte: CDHU &
\end{tabular}

Os dados fornecidos pelas tabelas 8 e 9 foram obtidos a partir dos projetos do Conjunto Marechal Tito e que foram disponibilizados pela CDHU. Os dados da Tabela 10 foram levantados a partir do Google Earth, do website www.guiamais.com.br e por meio de visitas ao local. 
Tabela 10 Distância dos principais serviços ao conjunto Marechal Tito Equipamentos e serviços comunitários

Escola de $1^{\circ}$ grau Existente/ dist. em

Escola de $2^{\circ}$ grau metros

Hospital/ Maternidade _..............

Crech

Posto Policial

1000

Campo de esportes

Feiras livres 400

Comércio Geral 50

Mercado 200

Cultos

Farmácia 150

Restaurantes 340

Banco 220

Indústrias

300

Conjuntos Habitacionais

Telefone público

Coleta de lixo

Coleta de lixo seletiva

50

50

A figura 7 apresenta o projeto de implantação do conjunto no terreno. 


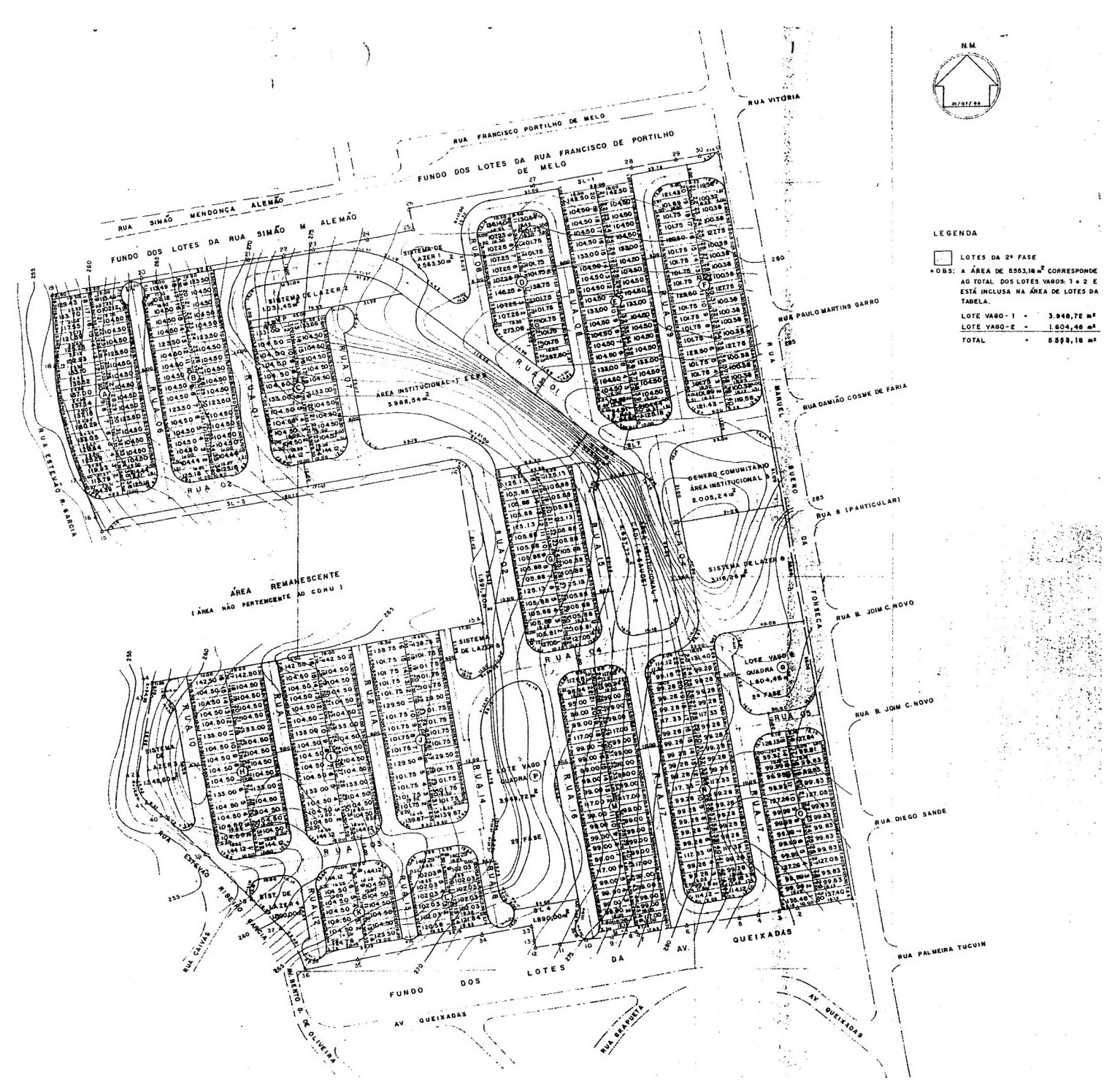

Figura 7 Planta de implantação do conjunto (fonte: $\mathrm{CDHU}$ ) 
Quase dez anos após a entrega das unidades, o conjunto encontra-se completamente desconfigurado, com exceção de algumas unidades que não fizeram nenhuma ampliação e deixaram a unidade como lhes foi fornecida. Atualmente, a maioria das casas possui dois pavimentos e o terreno temaproximadamente toda a sua área construída como é possível identificar nas nas figuras 8,9, 10 e 11:

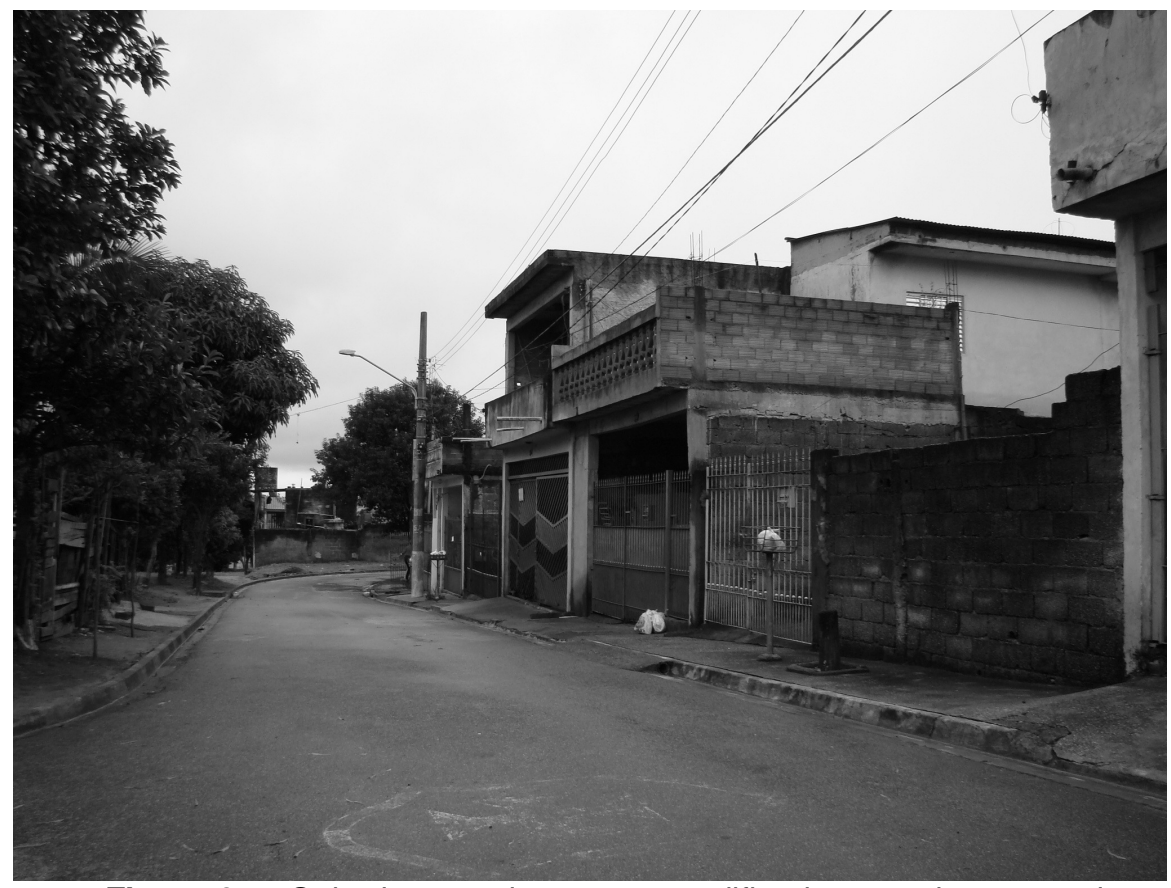

Figura 8 Gabarito completamente modificado - arquivo pessoal 


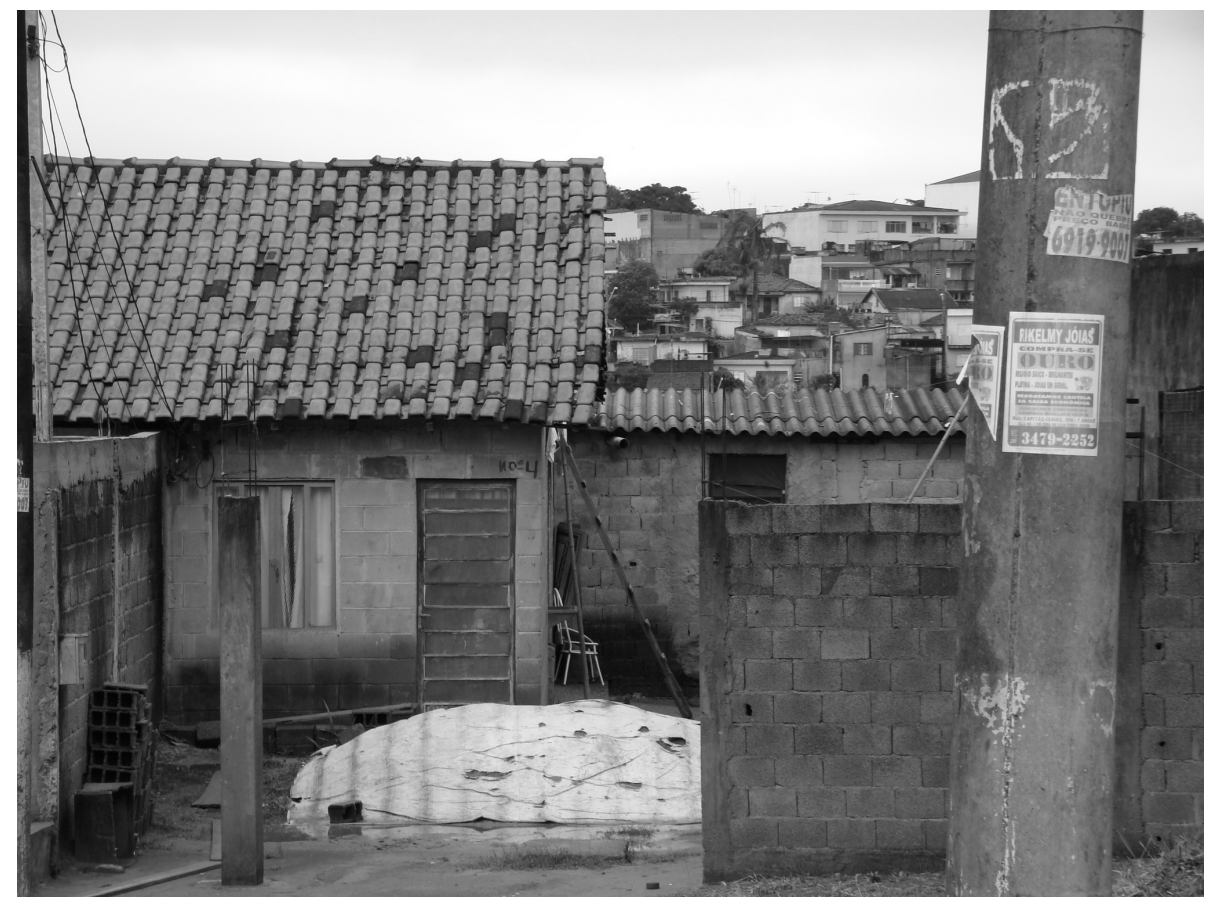

Figura 9 Unidade original do conjunto - o proprietário não efetuou qualquer alteração - arquivo pessoal

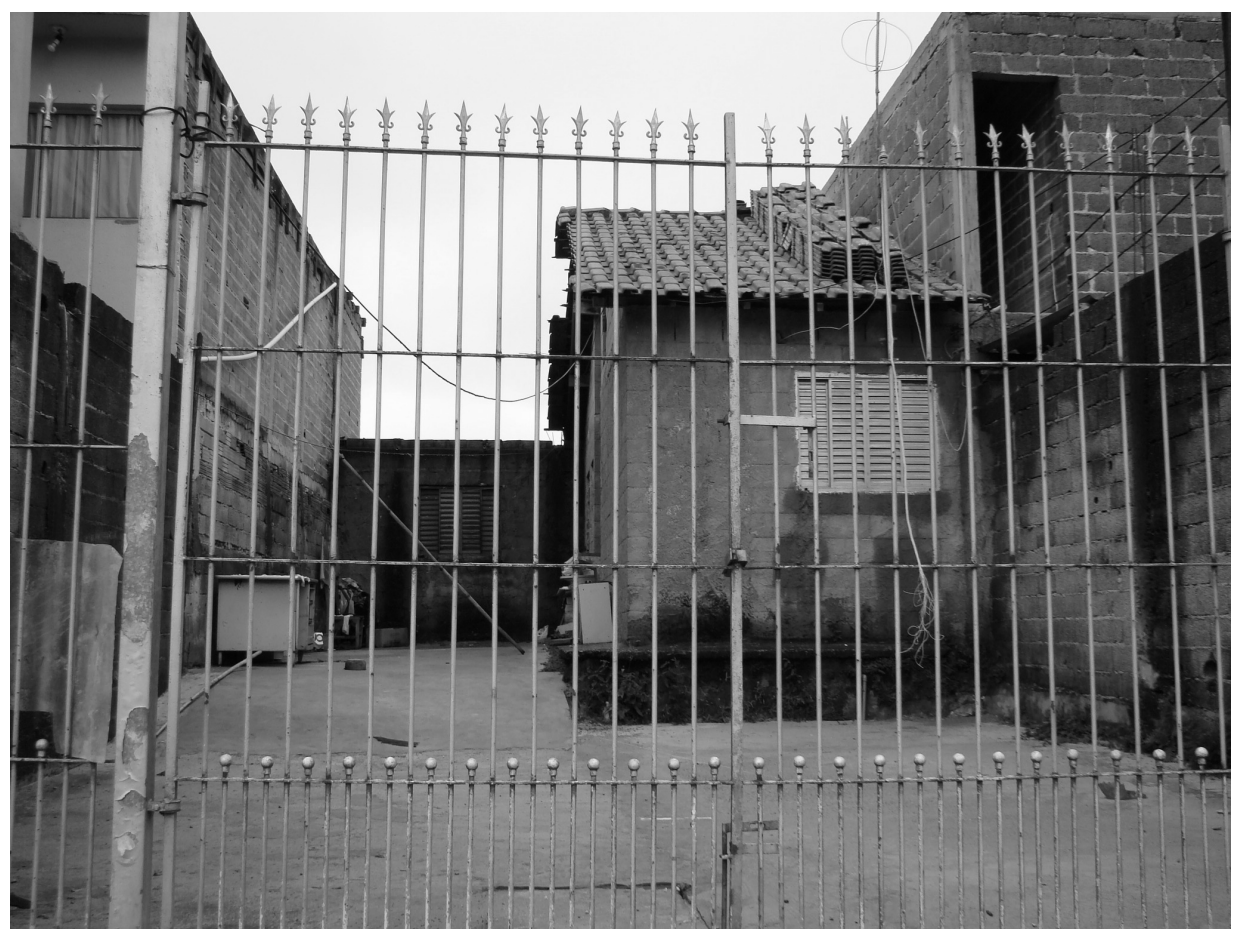

Figura 10 Nesta unidade, o proprietário só mudou a porta da frente para o lado - arquivo pessoal 


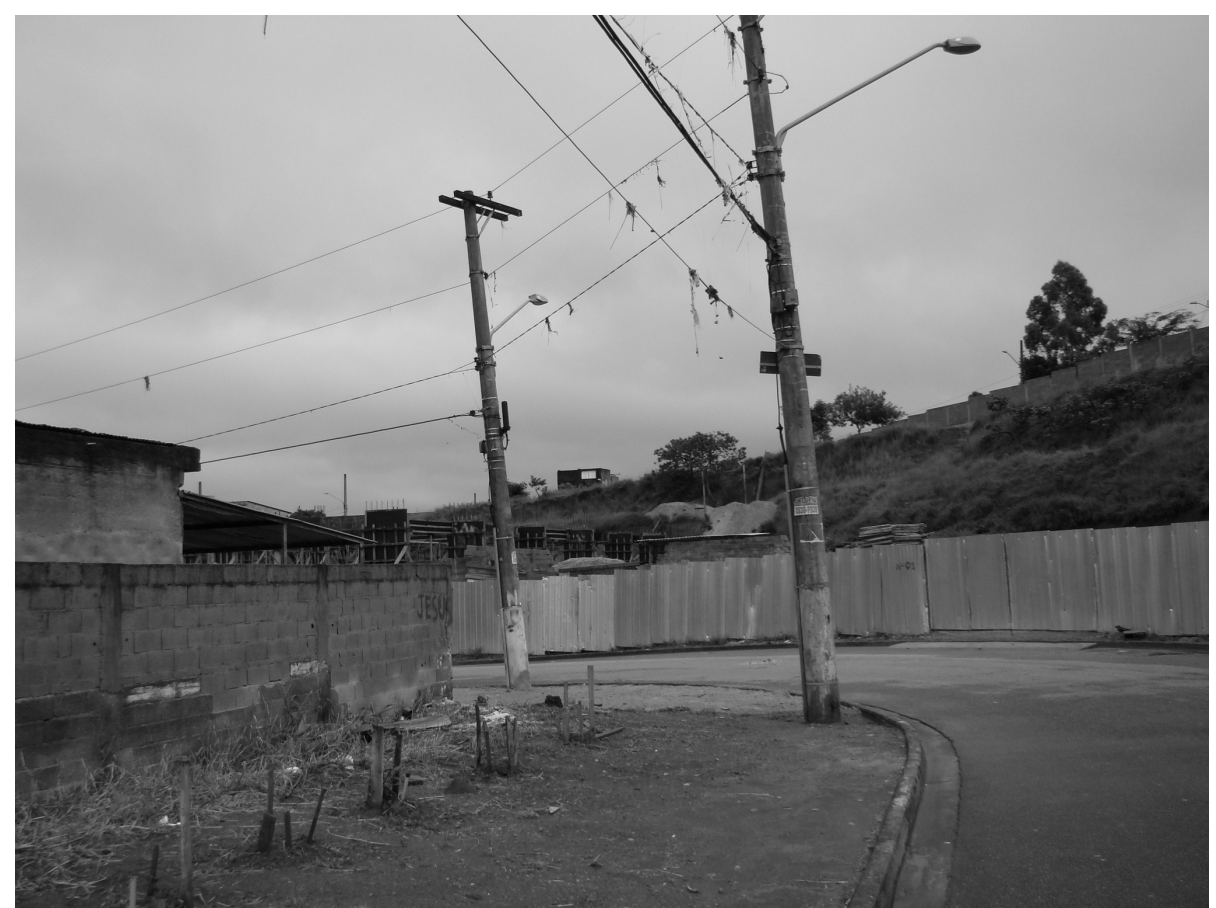

Figura 11 Área verde do conjunto - a grande inclinação do terreno, impossibilita o uso como área de lazer - arquivo pessoal

\subsection{O CONJUNTO HABITACIONAL ATIBAIA D}

O conjunto está localizado na cidade de Atibaia, a $67 \mathrm{~km}$ da cidade de São Paulo, fora da área da Região Metropolitana. O Município na época do censo em 2000 contava 111.300 habitantes.

A seguir são apresentados os dados do setor censitário em que o conjunto Atibaia D está inserido e que foram recolhidos pelo IBGE no Censo de 2000.

\section{Tabela 11 Detalhamento de dados do IBGE}

Código do setor censitário

Situação urbana

Tipo de setor

Domicílios particulares permanentes

Rendimento mensal médio da população (2000)
350410705000118
Área urbanizada de cidade ou vila

Comum

404

$R \$ 430,00$

De acordo com o relatório da CDHU, a área que foi destinada para o conjunto, fazia parte de uma gleba maior, adquirida pela Prefeitura e que ficava ao 
lado de um conjunto já construído, o Atibaia C. Atualmente, num dos terrenos vizinhos, está sendo desenvolvido um loteamento para classe média chamado Nova Atibaia. O terreno antes da construção do conjunto tinha vegetação rasteira e não possuía árvores, nem edificações existentes. A declividade é de aproximadamente $12 \%$ em direção ao córrego existente.

Levantamento do entorno do terreno:

Tabela 12 Levantamento do terreno de acordo com a CDHU

\begin{tabular}{ll} 
Zona de uso & Urbana \\
\hline Vias de acesso & Implantadas e pavimentadas \\
\hline Estado de conservação & Bom \\
\hline Existência de calçadas & Sim \\
\hline Existência de guias/sarjetas & Sim \\
\hline Classificação do entorno & Area urbana em expansão \\
\hline Distância ao centro/sub-centro & 100 metros \\
\hline Mercado de trabalho mais próximo & 800 metros \\
\hline Parada de ônibus/trem mais próxima & 200 metros \\
\hline Intervenções no terreno & Movimentação de terra \\
\hline Declividades e Acidentes & $90 \%$ to terreno com inclinação \\
Vegetação & de $5 \%$ a $10 \%$ \\
\hline Drenagem & Rasteira \\
\hline Camada superficial & $100 \%$ terreno seco
\end{tabular}

A tabela 12 mostra o levantamento feito pela CDHU a respeito do entorno do terreno. As vias de acessos estão implantadas e em boas condições, com calçadas e guias. O terreno é bem localizado, próximo a um centro de comércio e de trabalho. Para implantação do conjunto é necessária alguma movimentação de terra, visto que a declividade média é de aproximadamente $12 \%$. O terreno não é alagadiço e nem suscetível a inundações. 
A figura 11 apresenta duas imagens do conjunto em dois momentos diferentes: a imagem da esquerda é de 2003 e imagem da direita é de março de

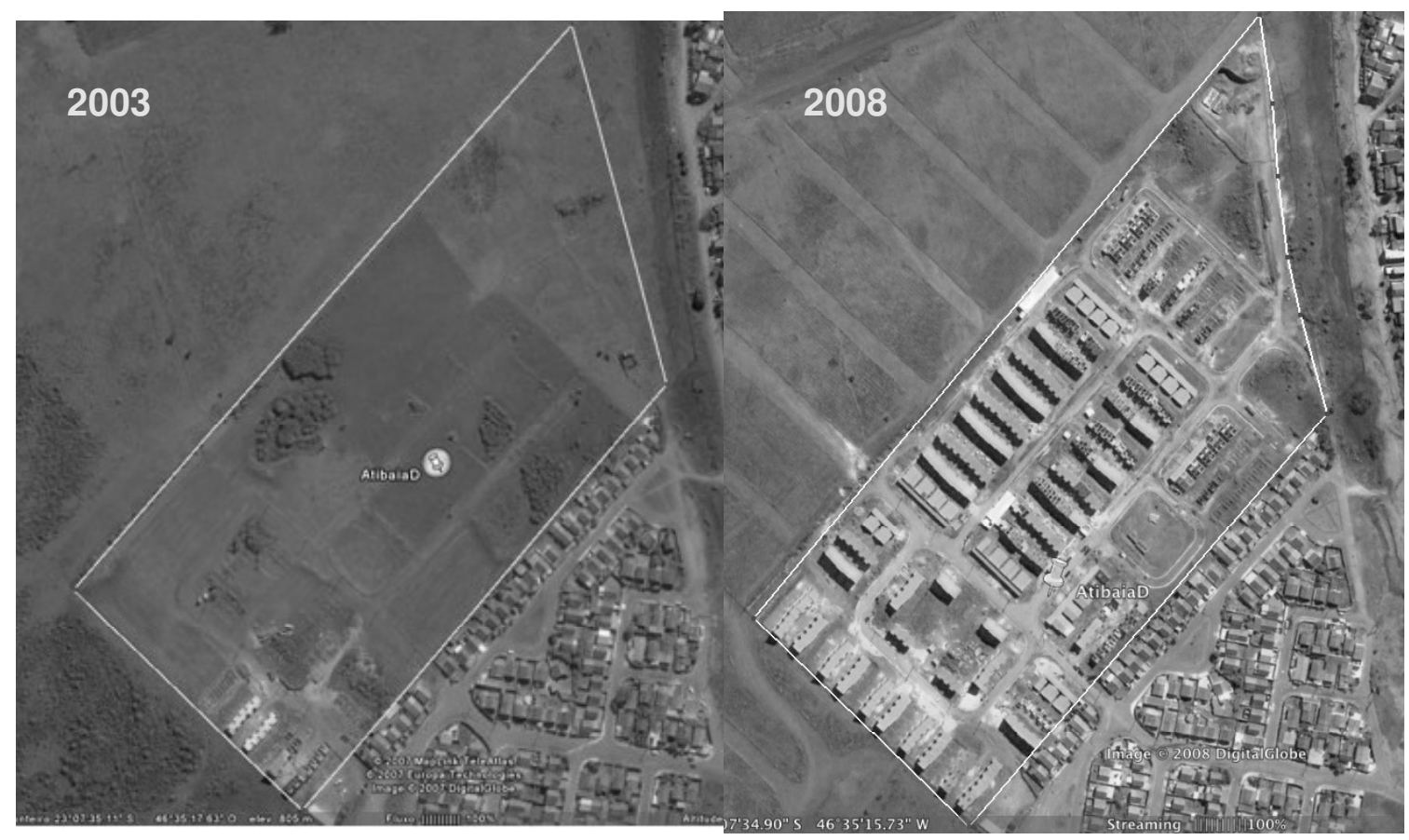

2008.

Figura 12 Evolução da fase de construção das unidades habitacionais a partir do Google Earth com imagem de 2003 e imagem de 2008 (acesso em jan/2007 e março de 2008)

As duas figuras mostram o terreno destinado ao conjunto. As duas imagens são do programa Google, na primeira, de 2003, aparece o trabalho de terraplanagem e as primeiras unidades construídas o começo do traçado das ruas e das quadras. Na segunda, de 2008, é possível observar o andamento da obra, cinco anos depois, quando a maior parte das unidades já está implantada e algumas estão em fase de finalização. Em relação ao entorno, é possível visualizar o novo loteamento, Nova Atibaia, que está em desenvolvimento nas áreas a noroeste e sudoeste do terreno. O conjunto Atibaia $C$ são as construções a sudeste do terreno. Hoje todas as ruas, tanto do Atibaia D como do entorno, estão implantadas e asfaltadas.

Seguindo o Manual de Projetos Técnicos, a CDHU faz um levantamento dos serviços oferecidos na região para atender a demanda do conjunto. Os 
serviços podem ser visualizados na tabela abaixo:

\begin{tabular}{|c|c|}
\hline $\begin{array}{l}\text { Equipamentos e serviços } \\
\text { comunitários }\end{array}$ & $\begin{array}{l}\text { Existente/ dist. em } \\
\text { metros }\end{array}$ \\
\hline Escola de $1^{\circ}$ grau & 100 \\
\hline Escola de $2^{\circ}$ grau & 150 \\
\hline Hospital/ Maternidade & 2000 \\
\hline Posto de saúde & 250 \\
\hline Creche & 250 \\
\hline Posto Policial & 700 \\
\hline Campo de esportes & 800 \\
\hline Feiras livres & 50 \\
\hline Comércio Geral & 200 \\
\hline Mercado & 300 \\
\hline Cultos & 250 \\
\hline Centro Comunitário & 500 \\
\hline Rede de água & 50 \\
\hline Rede de esgoto & 50 \\
\hline Rede de energia elétrica & 50 \\
\hline Rede de águas pluviais & 50 \\
\hline Indústrias & 1000 \\
\hline Campo de pouso & 3000 \\
\hline Cemitério & 2000 \\
\hline Conjuntos Habitacionais & 50 \\
\hline "'Telefone público & 200 \\
\hline Coleta de lixo & 50 \\
\hline Coleta de lixo seletiva & 50 \\
\hline
\end{tabular}

A tabela mostra todos os serviços existentes no entorno e sua distância até o terreno. O hospital, as indústrias e o cemitério são os serviços mais distantes. De forma geral os serviços estão bem próximos e o conjunto é bem localizado, além de possuir uma boa parte da infra-estrutura urbana já instalada.

O projeto do conjunto Atibaia $D$ é diferenciado não só pelo seu desenho, mas também pelos princípios de Ecodesign usados para seu desenvolvimento. Ele é fruto de uma iniciativa dos técnicos da CDHU que se organizaram e realizaram uma série de treinamentos para a equipe com o objetivo de incorporar princípios ambientais e sociais aos econômicos já existentes.

Após todo o treinamento da equipe de técnicos da CDHU, havia a necessidade de realizar um Projeto Piloto seguindo os princípios do Ecodesign. Em virtude disto a Companhia divulgou a intenção do projeto piloto entre alguns municípios e a Prefeitura de Atibaia manifestou o interesse de que este projeto piloto a ajudasse a suprir o seu déficit habitacional, levantado no ano de 2002 
como mais ou menos 5.300 unidades habitacionais (BARBOSA, 2002). Na época o Município possuía diversos moradores ocupando um aterro. Estes moradores viviam da comercialização dos resíduos encontrados no lixão. Por questões de salubridade, ele foi desativado pela CETESB, e a Prefeitura se comprometeu a remanejar a população e recuperar a área.

Em junho de 2001, o Município fechou totalmente o aterro e reativou uma usina de reciclagem para que a população continuasse a trabalhar em melhores condições, no entanto era ainda necessário o remanejamento dos moradores da favela ao redor do lixão. Com essa demanda imediata a Prefeitura fechou a parceria com a CDHU para que o projeto piloto fosse destinado a esta população em regime de mutirão.

Para a área do conjunto, foi escolhido um terreno a mais ou menos mil metros dali, ao lado do conjunto habitacional Atibaia C. Barbosa (2002) afirma que a escolha da tipologia já foi um diferencial, pois o empreendimento seria projetado em harmonia com o entorno e ao mesmo tempo serviria como um pólo de convivência entre a população da região.

Em relação ao desenho, ao contrário dos conjuntos tradicionais, o Atibaia $D$ apresenta grupos de unidades habitacionais geminadas, hierarquização de vias, duas características que Moretti (1997) recomenda para um melhor aproveitamento da infra-estrutura, diminuição dos custos de pavimentação e configuração de um ambiente exterior mais agradável e não tão monótono.

$O$ projeto foi elaborado na forma pequenas vilas, onde o acesso às unidades é feito a pé através de uma via mais estreita e inteiramente arborizada. O estacionamento para automóveis fica perpendicular ao acesso às unidades habitacionais, como é possível observar na figura 6 : 


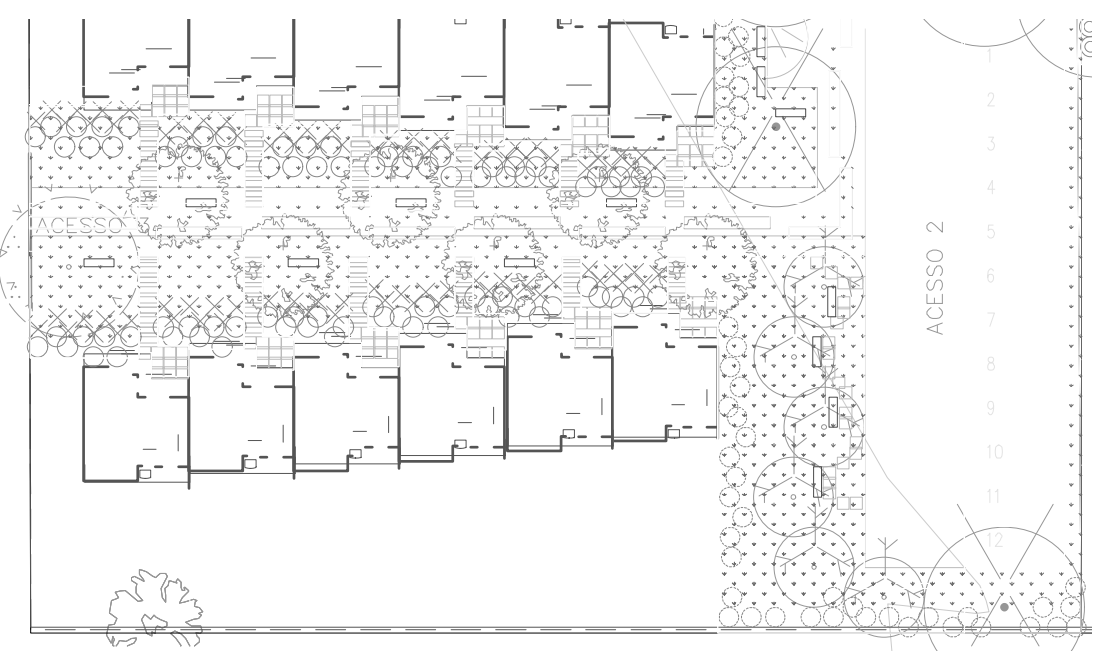

Figura 13 Ampliação de uma das vilas

Nesta figura, os carros são estacionados no acesso 02 , sendo que o projeto prevê uma vaga por unidade habitacional. $O$ acesso é feito pela alameda arborizada entre as duas fileiras de casas.

A planta de implantação geral do conjunto é apresentada a seguir: 


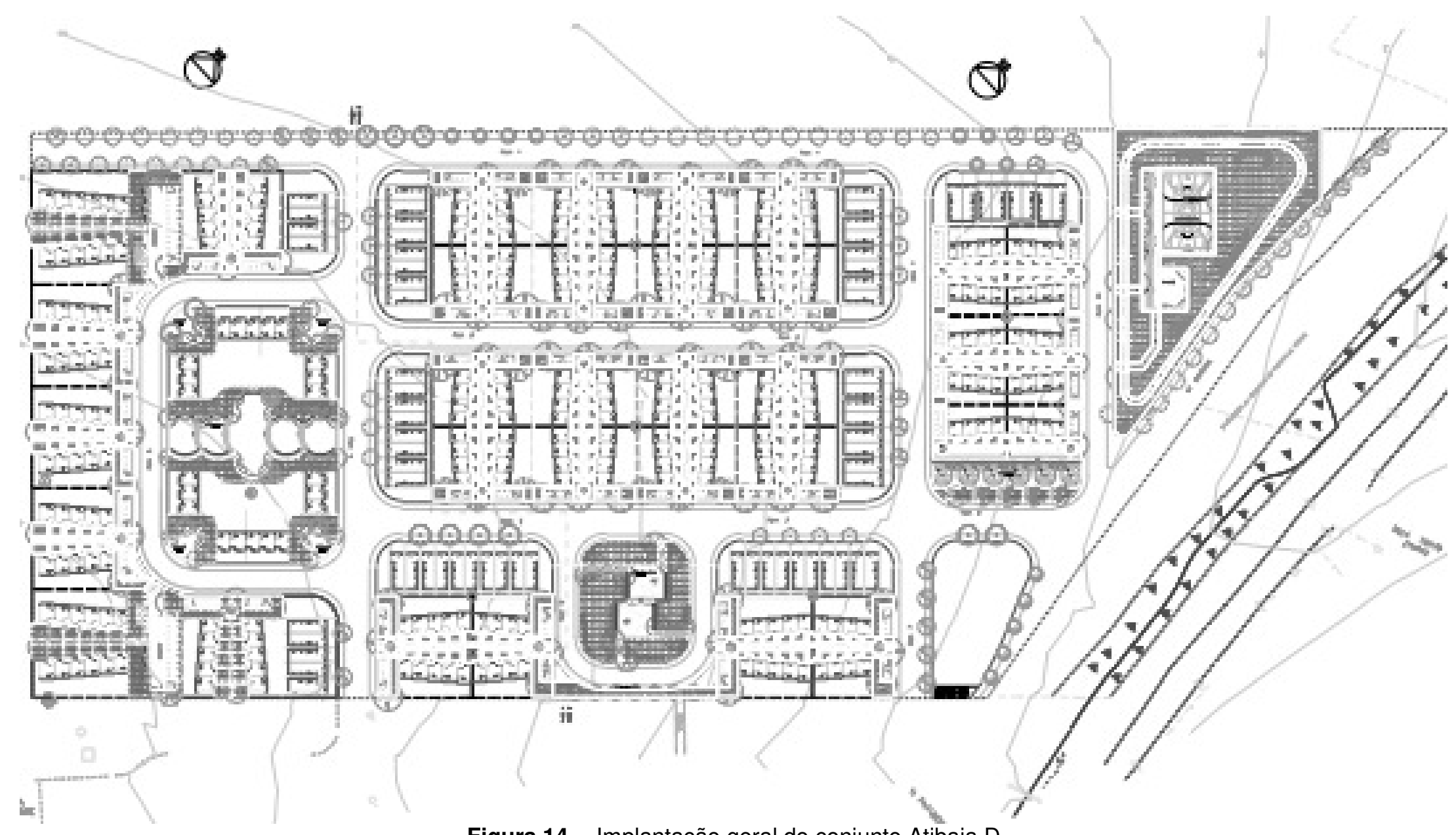

Figura 14 Implantação geral do conjunto Atibaia D 
Em relação aos princípios de Eco design, em 31 de março de 2005, foi firmada uma parceria entre a CDHU e a Prefeitura de Atibaia, por meio da Lei 3463, para a implantação do primeiro núcleo habitacional baseado em princípios de Eco design (Figueiredo, 2002). O Projeto de Ecodesign da CDHU prevê a geração de normas e guias de procedimento para a concepção e implementação de projetos habitacionais de interesse social, que tenham como base os princípios do Ecodesign e a avaliação contínua dos resultados.

De acordo ainda com Figueiredo (2002), Ecodesign: "É o projeto de empreendimentos habitacionais que incorporam conceitos de gestão ambiental e desenvolvimento sustentável".Apesar desta definição ser genérica, foram definidos alguns princípios a serem seguidos que são enumerados a seguir:

- Participação da população no projeto;

- Participação da população no planejamento da obra;

- Envolvimento da população na produção do espaço público e na criação de sistema de gerenciamento de recursos do conjunto habitacional (água, vegetação, energia e resíduos sólidos);

- Uso e preservação de recursos locais;

- Tecnologia adequada a mão-de-obra /usuários locais;

- Redução da geração de resíduos;

- Economia de energia e auto-sustentabilidade das fontes naturais;

Como programas previstos para diminuir o impacto ambiental do conjunto pode-se citar:

- Saneamento básico;

- Paisagismo (adensamento das áreas verdes/recomposição da vegetação nativa);

- Coleta seletiva de lixo;

- Uso da energia solar para aquecimento de água;

- Minimização de desperdícios na obra.

Em algumas unidades, o projeto conta com equipamentos para aquecimento da água por energia solar como é possível visualizar na figura 15: 


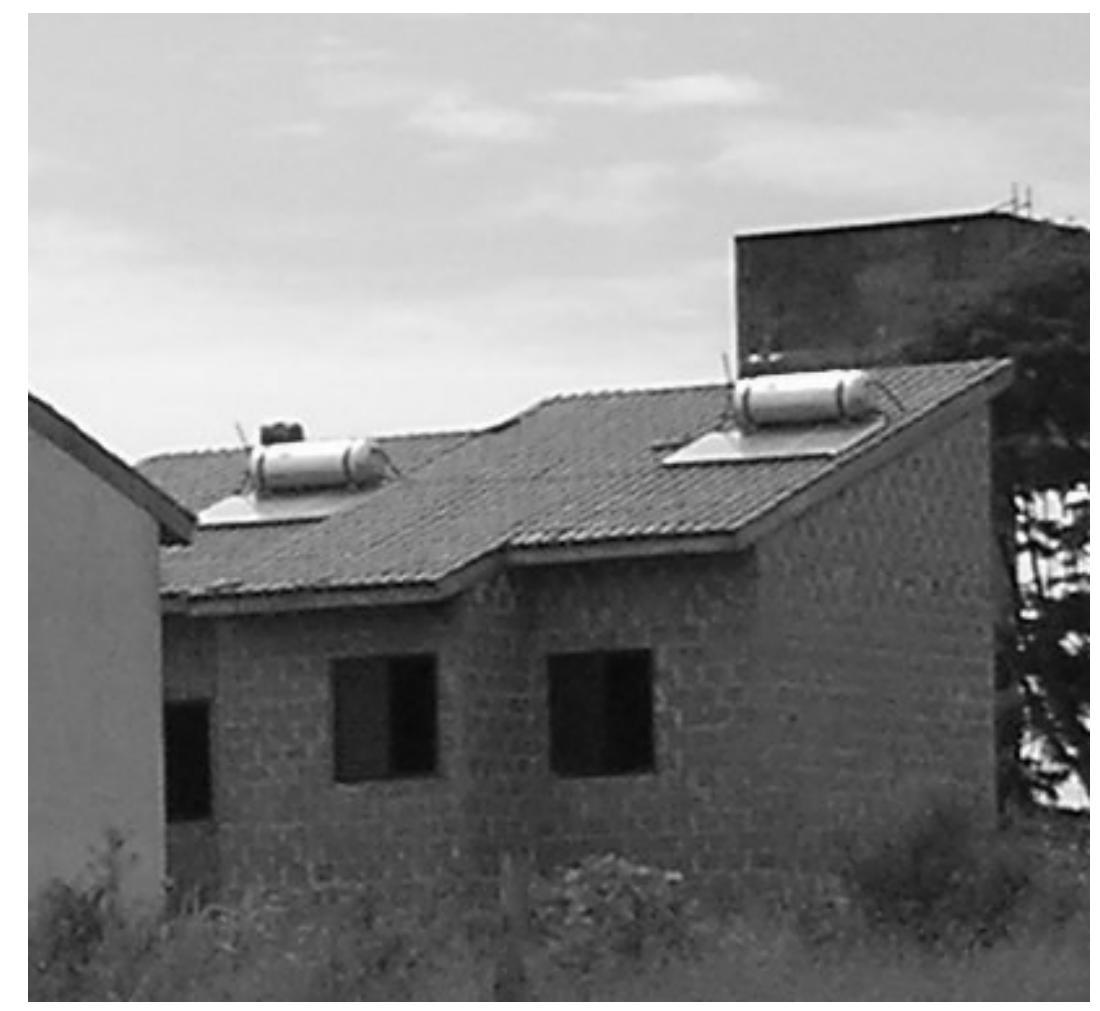

Figura 15 Unidades com o equipamento para aquecimento da água por energia solar implantado

Os números e dados técnicos do projeto estão enumerados na tabela 14:

Tabela 14 Dados do projeto, áreas e porcentagens de cada uso

\begin{tabular}{lcc}
\hline \multicolumn{1}{c}{ Terreno } & Area $\left(\mathrm{m}^{2}\right)$ & $\%$ \\
\hline Lotes & $83.090,36$ & 100,00 \\
\hline Lotes comerciais & $44.251,36$ & 53,26 \\
\hline Ruas & $1.521,13$ & 1,83 \\
\hline Sistemas de lazer & $25.260,72$ & 30,40 \\
\hline Equipamentos Comunitários & $10.278,97$ & 12,37 \\
\hline Equipamentos urbanos & $1.778,18$ & 2,14 \\
\hline Total & - & 0,00 \\
\hline Edificações & $83.090,36$ & 100 \\
\hline Sobrado & 55,36 & \\
\hline Casa térrea & 51,17 & \\
\hline Média do tamanho do lote & 119 & \\
\hline Fonte: CDHU &
\end{tabular}

A tabela 14 mostra a ocupação do solo com as áreas de cada uso e as respectivas porcentagens e as áreas das edificações. A unidades habitacionais ocupam cerca de $75 \%$ do lote individual, sendo que há espaço para ampliações no sobrado. 


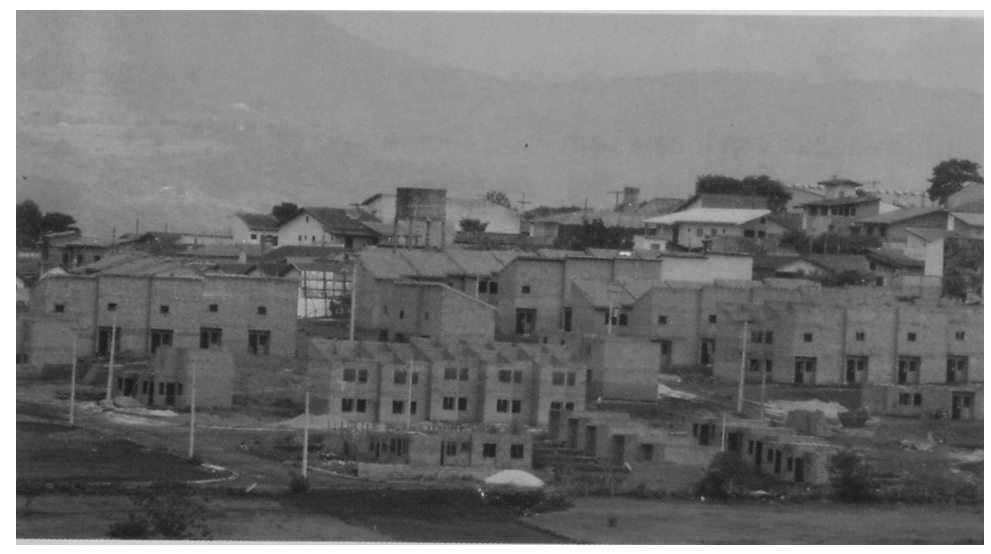

Figura 16 Vista geral do conjunto em construção (fonte: Prefeitura de Atibaia)

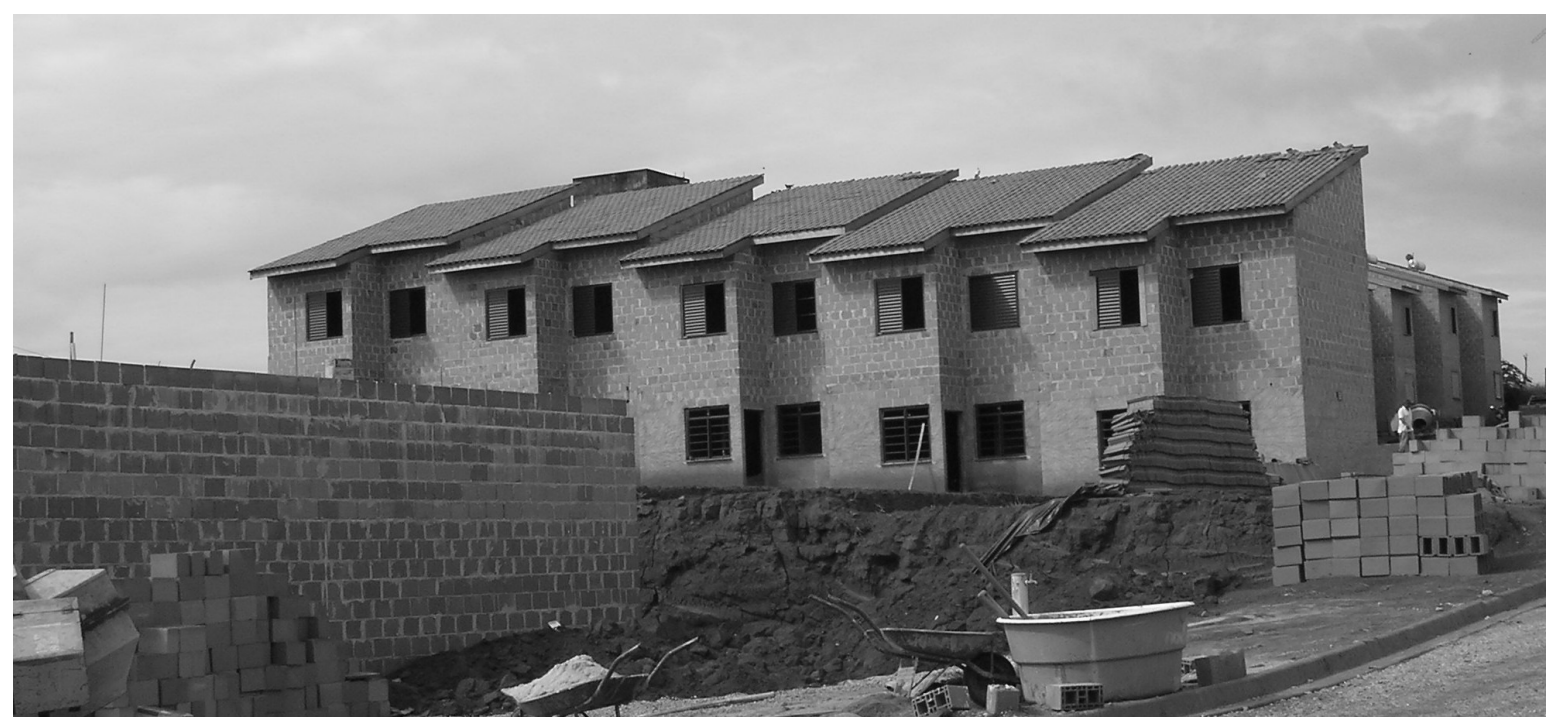

Figura 17 Vista de uma das vilas em construção pelo mutirão - arquivo pessoal

Os estudos de urbanização e de edificações elaborados pela CDHU previam 369 unidades habitacionais construídas parte em regime de empreitada global e parte por mutirão.

O conjunto conta com duas tipologias: 208 sobrados e 61 casas térreas. A construção das 369 unidades foi dividida em duas fases: 140 delas estão sendo construídas por mutirão e o restante por empreitada global efetuada por uma construtora contratada. Destas 140 unidades do mutirão, estão em fase de construção 26 casas térreas, e dentre estas térreas, 12 estão destinadas a deficientes físicos. 


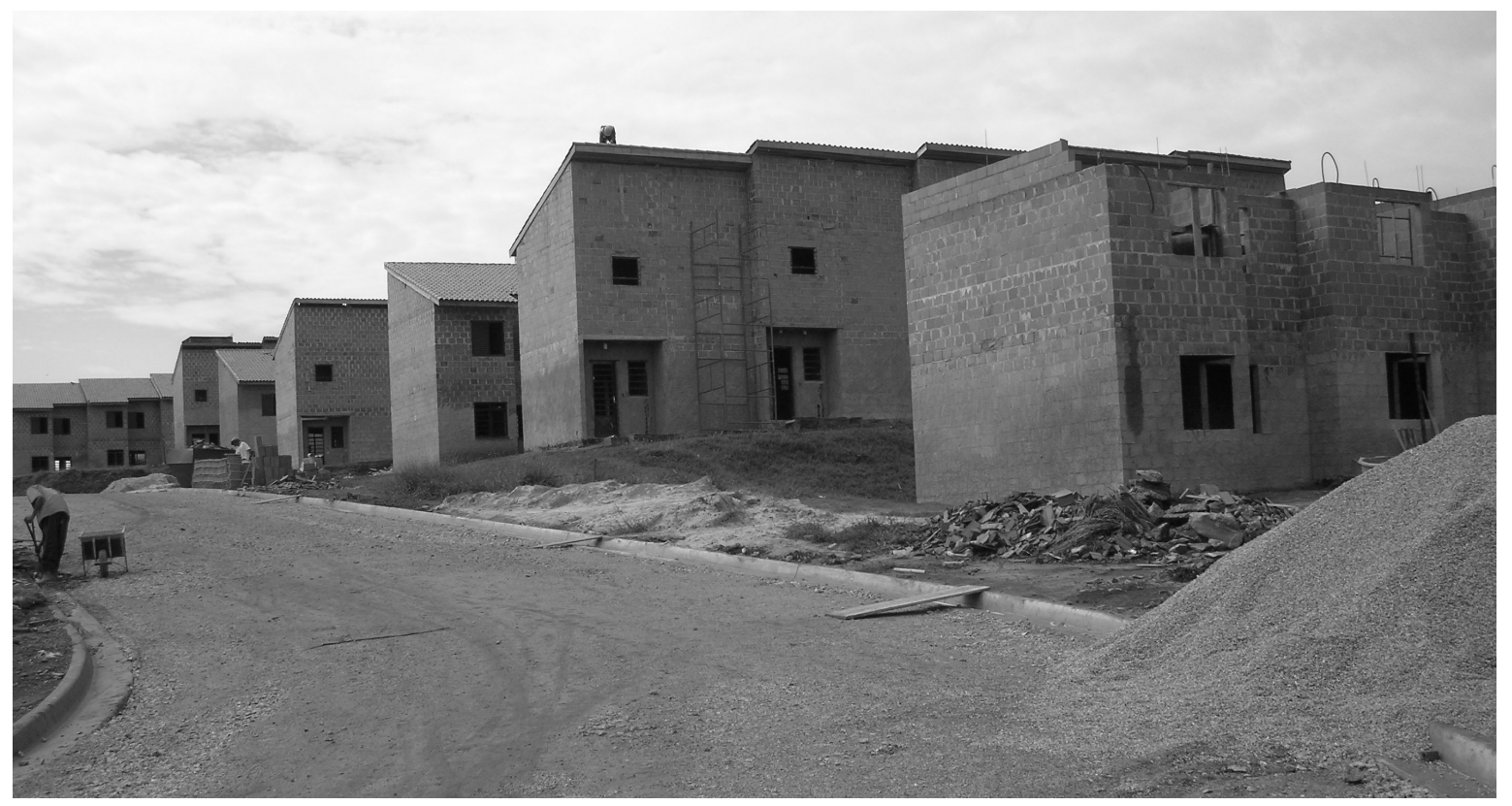

Figura 18 Vista de outras vilas em construção - arquivo pessoal

Todos os futuros habitantes estão recebendo treinamento para atividades de construção, manutenção e paisagismo do conjunto. Este último ficará sob a responsabilidade dos usuários, tanto a implantação como a manutenção. As obras começaram em 2004 e a previsão de término era o primeiro semestre de 2008 , com o atraso, talvez ao final de 2008 , o conjunto consiga ser entregue.

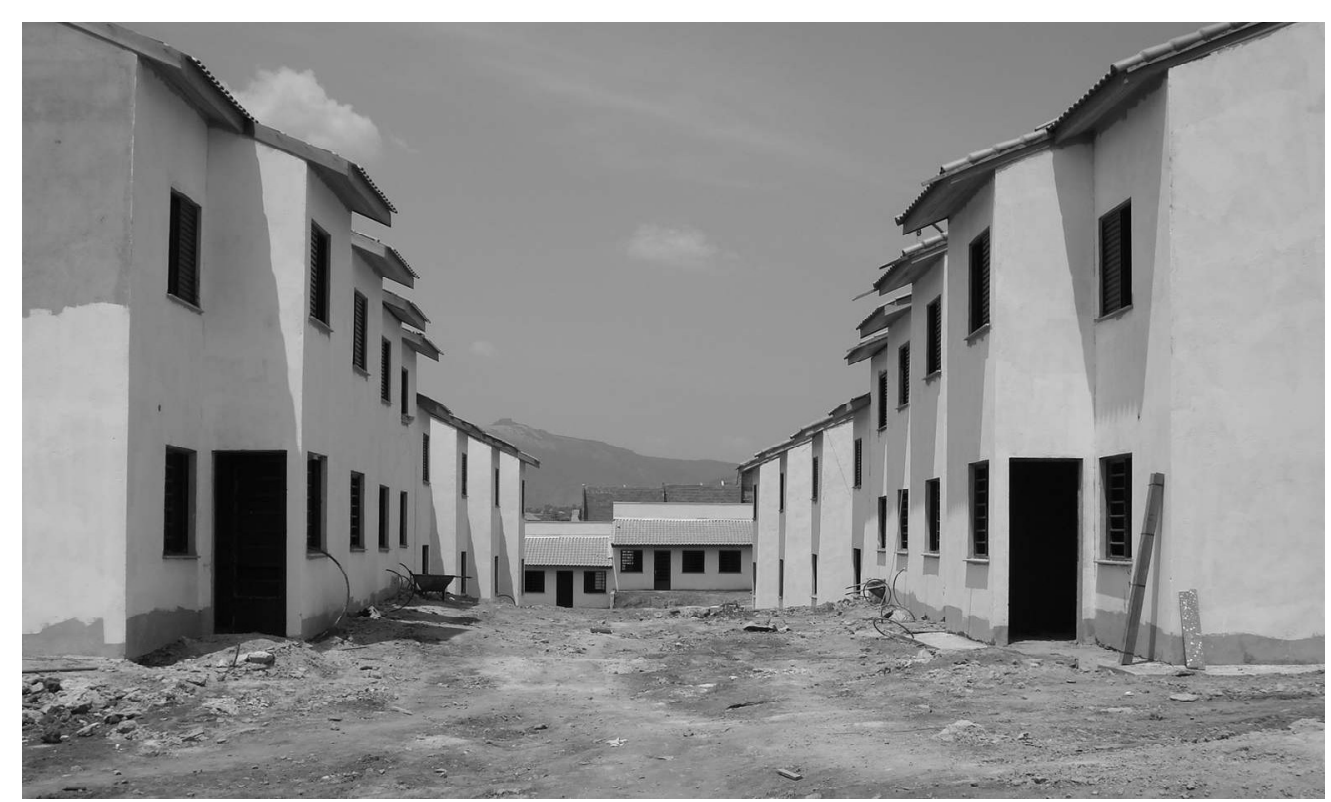

Figura 19 Vista das vilas acabadas do conjunto - arquivo pessoal 


\section{AVALIAÇÃO DOS CONJUNTOS PELOS MÉTODOS ESCOLHIDOS.}

A avaliação dos dois conjuntos será apresentada conjuntamente como já foi dito anteriormente. Os comentários a respeito dos principais aspectos da avaliação serão feitos ao final de cada quadro de avaliação.

Para a avaliação foram levantados os projetos junto à CDHU, dados do IBGE relacionados ao setor censitário em que cada conjunto está inserido, visitas ao local, e quando possível entrevistas com os projetistas, para esclarecimentos sobre os princípios norteadores dos projetos.

\subsection{AVALIAÇÃO PELO BREEAM - ECOHOMES}

Para que a avaliação fosse possível, foi utilizada uma planilha de "autoavaliação", a Ecohomes 2006 Pre Assessment Estimator fornecida pelo BREEAM. A planilha contém as porcentagens referentes ao total da pontuação que podem ser atingida em cada uma das sub-categorias e no total. Esta planilha serve para que os projetistas tenham uma idéia da classificação que o empreendimento poderá obter. O resultado final neste caso, também é dado em porcentagem. A tabela 15 apresenta a avaliação do Ecohomes: 
Tabela 15 Avaliação pelo Ecohomes com suas categorias principais

\begin{tabular}{|c|c|c|c|c|}
\hline \multicolumn{2}{|c|}{$\begin{array}{l}\text { Ecohomes } 2006 \text { Estimativa da Pré Avaliação } \\
\text { Item }\end{array}$} & $\begin{array}{l}\text { Habitação Entorno } \\
\% \text { do total }\end{array}$ & \multirow[t]{2}{*}{$\begin{array}{l}\text { Marechal } \\
\text { Tito }\end{array}$} & \multirow[t]{2}{*}{ Atibaia D } \\
\hline \multicolumn{3}{|c|}{ ENERGIA } & & \\
\hline Ene 1 & $\begin{array}{l}\text { Taxa de Emissão da habitação } \\
\text { os pontos são ganhos a partir de menos de } 40 \text { até - } \\
10 \mathrm{~kg} / \mathrm{m} 2 / \mathrm{ano}\end{array}$ & 13,75 & - & 0 \\
\hline Ene 2 & $\begin{array}{l}\text { Desempenho do envelope do edificio } \\
\text { a pontuação é obtida quando o desempenho término } \\
\text { basado nos HLP - parametros de perda de calor encontro } \\
\text { os seguintes critérios } \\
\text { HLP }<1.3 \text { ou } 1,1 \mathrm{~W} / \mathrm{m} 2 \mathrm{~K}\end{array}$ & 1,83 & - & 0 \\
\hline Ene 3 & Espaço para secagem de roupas & 0,92 & 0,92 & 0,92 \\
\hline Ene 4 & Eletrodomésticos com selo de consumo de energia "A" & 1,83 & 0 & 0 \\
\hline Ene 5 & $\begin{array}{l}\text { lluminação intena } \\
\text { Especificação de lampadas de baixo consumo de energia }\end{array}$ & 1,83 & 0 & 0 \\
\hline Ene 6 & $\begin{array}{l}\text { Iluminação externa } \\
\text { Iluminação para espaços externos e para segurança }\end{array}$ & 1,83 & 0 & 0 \\
\hline Total c & orcentagens dos créditos para ENERGIA & 22 & 0,92 & 0,92 \\
\hline \multicolumn{5}{|c|}{ TRANSPORTE } \\
\hline Tra 1 & Transporte público & 2 & 2 & 2 \\
\hline Tra 2 & Armazenamento de bicicletas & 2 & 0 & 0 \\
\hline Tra 3 & Proximidade de serviços & 3 & 3 & 3 \\
\hline Tra 4 & Espaço para escritório em casa & 1 & 0 & 0 \\
\hline Total p & transporte & 8 & 5 & 5 \\
\hline \multicolumn{5}{|c|}{ POLUIÇÃO } \\
\hline Pol 1 & $\begin{array}{l}\text { Materiais isolantes } \\
\text { Materiais com GWP menor que } 5 \text { e ODP de zero }\end{array}$ & 0,91 & & - \\
\hline Pol 2 & $\begin{array}{l}\text { Emissões de Nox } \\
<100 \mathrm{NOx} \mathrm{mg} / \mathrm{kWh} \text { até }<40 \mathrm{NOx} \mathrm{mg} / \mathrm{kWh}\end{array}$ & 2,73 & - & - \\
\hline Pol 3 & Redução da água de enxurrada & 1,82 & 0 & 1,82 \\
\hline Pol 4 & Fontes de energia renovável e de baixa emissão & 2,73 & - & - \\
\hline Pol 5 & Diminuição do risco de inundação & 1,82 & 1,82 & 1,82 \\
\hline Total p & POLUIÇÁO & 10 & 1,82 & 3,64 \\
\hline \multicolumn{5}{|c|}{ MATERIAIS } \\
\hline Mat 1 & $\begin{array}{l}\text { Impacto ambiental dos materiais } \\
\text { Materiais considerados: telhado, paredes externas e } \\
\text { internas, pisos, janelas, acabamento externo, muros } \\
\end{array}$ & 7,23 & & \\
\hline Mat 2 & $\begin{array}{l}\text { Fonte responsável dos materiais: elementos básicos do } \\
\text { edificio } \\
\text { Estrutura, piso terreo e superiores, cobertura, parades } \\
\text { externas e internas, fundações, vedações e escadas }\end{array}$ & 2,71 & 0 & 0 \\
\hline Mat 3 & $\begin{array}{l}\text { Fonte responsável dos materiais: elementos de } \\
\text { acabamento }\end{array}$ & 1,35 & & \\
\hline Mat 4 & $\begin{array}{l}\text { Estrutura para reciclagem } \\
\text { Lugar para armazenamento interno e/ou externo }\end{array}$ & 2,71 & & \\
\hline Total p & MATERIAIS & 14 & 0 & 0 \\
\hline \multicolumn{5}{|c|}{ ÁGUA } \\
\hline Wat 1 & $\begin{array}{l}\text { Uso interno de água potável } \\
\text { de menos de } 52 \text { a } 32 \mathrm{~m} 3 / \text { cama/ano }\end{array}$ & 8,33 & 8,33 & 8,33 \\
\hline$\overline{\text { Wat } 2}$ & $\begin{array}{l}\text { Uso externo de água potável } \\
\text { Estrutura para armazenamento da água da chuva }\end{array}$ & 1,67 & 0 & 0 \\
\hline Total p & ÁGUA & 10 & 8,33 & 8,33 \\
\hline \multicolumn{5}{|c|}{ USO DA TERRA E ECOLOGIA } \\
\hline Eco 1 & Valor ecológico do terreno & 1,33 & 1,33 & 1,33 \\
\hline Eco 2 & Aumento do valor ecológico & 1,33 & 0 & 1,33 \\
\hline Eco 3 & Proteção às características ecológicas & 1,33 & 0 & 1,33 \\
\hline Eco 4 & Mudança do valor ecológico do terreno & 5,33 & 0 & 0 \\
\hline Eco 5 & Pegada do edifício & 2,67 & 0 & 0 \\
\hline Total p & USO DA TERRA E ECOLOGIA & 12 & 1,33 & 3,99 \\
\hline
\end{tabular}




\begin{tabular}{|c|c|c|c|c|c|}
\hline \multicolumn{4}{|c|}{ SAÚDE E BEM-ESTAR } & & \\
\hline Hea 1 & Luz do dia & \multicolumn{2}{|l|}{5,25} & & \\
\hline Hea 2 & Isolamento acústico & \multicolumn{2}{|l|}{7} & 0 & 0 \\
\hline Hea 3 & Espaço privado & \multicolumn{2}{|l|}{1,75} & 1,75 & 1,75 \\
\hline \multicolumn{2}{|c|}{ Total para SAÚDE E BEM-ESTAR } & \multicolumn{2}{|l|}{14} & 1,75 & 1,75 \\
\hline \multicolumn{6}{|c|}{ GERENCIAMENTO } \\
\hline$\overline{M a n} 1$ & Guia do morador & \multicolumn{2}{|l|}{3} & 0 & 0 \\
\hline Man 2 & Compromisso com boas práticas na construção & \multirow{2}{*}{\multicolumn{2}{|c|}{$\frac{2}{3}$}} & 0 & 0 \\
\hline Man 3 & Impactos da construção no terreno & & & 0 & 0 \\
\hline Man 4 & $\begin{array}{l}\text { Segurança } \\
\text { portas e janelas com padrão de segurança de acordo com } \\
\text { as normas inglesas }\end{array}$ & \multicolumn{2}{|l|}{2} & 0 & 0 \\
\hline Total pa & a GERENCIAMENTO & \multicolumn{2}{|l|}{10} & 0 & 0 \\
\hline TOTAL & ARA TODAS AS SEÇOES & \multicolumn{2}{|c|}{100} & 19,15 & 23,63 \\
\hline
\end{tabular}

O Ecohomes foi um dos métodos mais difíceis de serem aplicados aos dois conjuntos. De uma maneira geral, o método como está não é aplicável às características dos conjuntos habitacionais, nem às habitações brasileiras em geral. A porcentagem alcançada pelo conjunto Marechal Tito foi de 19,15\% e pelo Atibaia $D$ foi de $23,63 \%$, ou seja, não se conseguiu chegar aos $36 \%$ para obter a classificação Aprovado (Pass). A razão da baixa porcentagem pode ser explicada principalmente por dois motivos:

1) é um método muito restrito às normas do Reino Unido ou da União Européia e que ou não existem ou não encontram equivalência na norma brasileira. Como por exemplo, a taxa de emissão de materiais isolantes térmicos ou ainda a perda de calor da edificação para o meio externo.

2) é extremamente voltado para a avaliação da edificação, deixando poucos indicadores para avaliação da localização do empreendimento e do entorno.

Uma outra razão também para a baixa pontuação foi que não se tentou "forçar" a avaliação por alguns indicadores como por exemplo o "Fator de luz do dia”. Apesar de não possuir as especificações dos vidros sabe-se que pela sua localização - na área tropical - o Brasil e a região de São Paulo possuem uma luminosidade muito mais alta que a do Reino Unido.

Nesta planilha de auto-avaliação, o método separa os créditos exclusivos ao edifício e os créditos relativos à localização do empreendimento. Os créditos referentes à localização do empreendimento e relacionamento com o entorno são:

- Transporte público; 
- Infra-estrutura de serviços locais;

- Valor ecológico do terreno;

- Aumento do valor ecológico do terreno;

- Proteção às características ecológicas;

- Mudança do valor ecológico do terreno;

- Boas práticas no processo construtivo;

- Gerenciamento dos impactos durante o período de construção no meio ambiente;

Juntos, estes indicadores são responsáveis por apenas $15 \%$ da pontuação geral. A grande parte dos outros indicadores não foi possível de ser atendida por falta de dados como qualidade do ar interno, emissões geradas a partir do processo de manufatura dos materiais usados, entre outros

O Ecohomes não possui indicadores para avaliação do desenho urbano, por isso há somente uma pequena diferenciação entre a avaliação do Atibaia $D$ e do Marechal Tito. $O$ único indicador que diferencia os dois é o aumento do valor ecológico em que o Atibaia $D$ apresenta uma preocupação com o paisagismo e o Marechal Tito não.

De uma maneira geral, a avaliação dos conjuntos pelo Ecohomes foi bem difícil, existem vários indicadores que não são aplicáveis aos conjuntos nem à realidade brasileira. A metodologia demanda dados que o Brasil não possui seja pela diferença de tipo de clima, seja pelo fato de possuir um outro tipo de matriz energética. Por este motivo também não é possível medir o consumo de energia associada à emissão de $\mathrm{CO} 2$.

\subsection{AVALIAÇÃO PELO SBAT}

A estrutura geral do sistema é dividida em três grandes categorias: social, econômica e ambiental. Cada categoria é dividida em 5 subcategorias com 5 indicadores cada uma, cada indicador da subcategoria corresponde a uma porcentagem, esta porcentagem é equivalente a uma pontuação que varia de 0 a 1 . A soma dos pontos de cada indicador corresponde à pontuação à da 
subcategoria. Por sua vez cada subcategoria é ponderada e o resultado final é o resultado da categoria. O resultado final da avaliação é a média aritmética das notas de cada uma das três categorias. A avaliação pelo método é demonstrada a seguir:

Tabela 16 Avaliação dos dois conjuntos pela categoria Social do SBAT

\begin{tabular}{|c|c|c|c|c|c|c|}
\hline \multirow{3}{*}{ SOCIAL } & \multirow{3}{*}{ Item } & \multirow[b]{3}{*}{ Indicador } & \multirow{2}{*}{\multicolumn{2}{|c|}{ Mar Tito }} & & \\
\hline & & & & & \multicolumn{2}{|c|}{ Atibaia D } \\
\hline & & & $\%$ & Pts & $\%$ & Pts \\
\hline SO 1 & & Conforto do Ocupante & & 2,0 & & 2,0 \\
\hline SO 1.1 & Luz do dia & $\begin{array}{l}\text { \% dos espaços ocupados que estão dentro de uma distância } \\
\text { duas vezes maior que a altura da janela }\end{array}$ & 100 & 1,0 & 100 & 1,0 \\
\hline SO 1.2 & Ventilação & $\begin{array}{l}\text { \% dos espaços ocupados que são equivalentes à area de } \\
\text { abertura das janelas equivalentes a } 10 \% \text { da área de piso ou } \\
\text { sistemas mecânicos com fonte de ar ñ poluído }\end{array}$ & 100 & 1,0 & 100 & 1,0 \\
\hline SO 1.3 & Ruido & $\begin{array}{l}\text { \% dos espaços ocupados onde a reverberação interna ou } \\
\text { externa não atrapalhe um conversa normal de 50dBA }\end{array}$ & 0 & 0,0 & 0 & 0,0 \\
\hline SO 1.5 & Conforto térmico & $\begin{array}{l}\text { Temperatura dos espaços ocupados não ultrapassam } 280 \mathrm{C} \text { ou } \\
190 \mathrm{C} \text { durante mais que cinco dias no ano }\end{array}$ & 0 & 0,0 & 0 & 0,0 \\
\hline SO 1.5 & vistas & $\begin{array}{l}\% \text { dos espaços ocupados que estão } 6 \mathrm{~m} \text { de uma janela com vista } \\
\text { para o exterior }\end{array}$ & 0 & 0,0 & 0 & 0,0 \\
\hline SO 2 & & Ambiente inclusivo & & 1,0 & & 1,6 \\
\hline SO 2.1 & Transporte público & $\begin{array}{l}\text { \% dos edifícios dentro de } 400 \mathrm{~m} \text { de transporte público com } \\
\text { infraestrutura para pessoas com dificuldade de locomoção }\end{array}$ & 100 & 1,0 & 100 & 1,0 \\
\hline SO 2.2 & Informação & Comunicação visual clara, contrastante e bem localizada & 0 & 0,0 & 0 & 0,0 \\
\hline SO 2.3 & Espaço & $\begin{array}{l}\text { \% dos espaços ocupados que são totalmente acessíveis a } \\
\text { cadeira de rodas }\end{array}$ & 0 & 0,0 & 60 & 0,6 \\
\hline SO 2.4 & Banheiros & $\begin{array}{l}\% \text { dos espaços com acesso a banheiros dentro de um raio de } \\
50 \mathrm{~m}\end{array}$ & 0 & 0,0 & 0 & 0,0 \\
\hline SO 2.5 & Mobília e mobiliário & \% do mobilário e espaços acessíveis para cadeirantes & 0 & 0,0 & 0 & 0,0 \\
\hline SO 3 & & Acesso às facilidades & & 4,5 & & 4,0 \\
\hline SO 3.1 & Crianças & $\begin{array}{l}\text { Todos os usuários podem caminhar / usar transorte publico para } \\
\text { pegar ou levar crianças na escola ou creche }\end{array}$ & 100 & 1,0 & 100 & 1,0 \\
\hline SO 3.2 & Bancos & $\begin{array}{l}\text { Todos os usuários podem andar/ usar transporte público para ir } \\
\text { ao banco }\end{array}$ & 100 & 1,0 & 50 & 0,5 \\
\hline SO 3.3 & Comércio & $\begin{array}{l}\text { Todos os usuários podem andar/ usar transporte público para ir } \\
\text { a lojas ou comércio }\end{array}$ & 100 & 1,0 & 50 & 0,5 \\
\hline SO 3.4 & Comunicação & $\begin{array}{l}\text { Porcentagem dos habitante que andam/ usam tranporte público } \\
\text { para correio / telefone/ internet }\end{array}$ & 100 & 1,0 & 100 & 1,0 \\
\hline SO 3.5 & Exercícios & $\begin{array}{l}\text { Todos os usuários podem andar/ usar transporte público para } \\
\text { praticar exercícios ou ir a lugares para recreação }\end{array}$ & 50 & 0,5 & 100 & 1,0 \\
\hline SO 4 & & Participação e controle & & 1,0 & & 2,5 \\
\hline SO 4.1 & Controle ambiente & \% dos espaços ocupados que têm controle da temperatura & 0 & 0,0 & 0 & 0,0 \\
\hline SO 4.2 & envolvimento & $\%$ dos usuários ativamente envolvidos no processo de projeto & 0 & 0,0 & 50 & 0,5 \\
\hline SO 4.3 & Espaços sociais & Espaços para reuniões informais dentro de um raio de $400 \mathrm{~m}$ & 100 & 1,0 & 100 & 1,0 \\
\hline SO 4.4 & $\begin{array}{l}\text { divisão de tarefas } \\
\text { para operação e } \\
\text { manutenção }\end{array}$ & $\begin{array}{l}5 \% \text { das atividades de manutenção e operação divididas entre os } \\
\text { usuários/ organização semanal }\end{array}$ & 0 & 0,0 & 0 & 0,0 \\
\hline SO 4.5 & Grupos de usuários & $\begin{array}{l}\text { Grupo representante que esteja ativamente envolvido com o } \\
\text { gerenciamento do empreendimento }\end{array}$ & 0 & 0,0 & 100 & 1,0 \\
\hline SO 5 & & Educação, saúde e seguranca & 0 & 0,0 & 0 & 0,0 \\
\hline SO 5.1 & Educação & $\begin{array}{l}2 \% \text { ou mais de espaço ou infraestrutura destinado para } \\
\text { educação por } 75 \% \text { de espaço ocupado. Treinamento para } \\
\text { construção }\end{array}$ & 0 & 0,0 & 0 & 0,0 \\
\hline SO 5.2 & Segurança & $\begin{array}{l}\text { Todas as rotas internas e externas ou empreendimento bem } \\
\text { iluminadas, visualmente supervisionadas. Perimetro seguro e } \\
\text { controle de acesso, sem crime }\end{array}$ & 0 & 0,0 & 0 & 0,0 \\
\hline SO 5.3 & Cuidados & $\begin{array}{l}\text { \% dos usuários que têm acesso a informação sobre saúde e } \\
\text { segurança, oportunidades de emprego e treinamento fácil }\end{array}$ & 0 & 0,0 & 0 & 0,0 \\
\hline SO 5.4 & Materiais & $\begin{array}{l}\text { Todos os materiais / componentes usados não possuem efeito } \\
\text { negativo na qualidade do ar interno }\end{array}$ & 0 & 0,0 & 0 & 0,0 \\
\hline SO 5.5 & Acidentes & $\begin{array}{l}\text { Método no local para registro de todos os acidentes ou doenças } \\
\text { ocupacionais e que sejam atendidos }\end{array}$ & 0 & 0,0 & 0 & 0,0 \\
\hline
\end{tabular}


A Categoria Social é dividida em cinco subcategorias que avaliam: conforto do ocupante, o quanto o ambiente tem capacidade para integrar e incluir as pessoas, o acesso a serviços, a participação dos usuários e saúde, segurança e educação.

A primeira sub-categoria visa garantir o conforto do ocupante em relação à iluminação natural, ventilação, ruído, vistas, a segunda trata dos acessos a serviços e infra-estrutura urbana e a quarta e quinta abordam algumas responsabilidades sociais que podem ser atendidas pela construção civil como, por exemplo: infra-estrutura destinada à educação, segurança dos espaços públicos, informações e instrução sobre doenças que possam ser evitadas com alguns pequenos cuidados.

A subcategoria acesso às facilidades é um pouco confusa uma vez que considera 0 acesso tanto por transporte público como a pé. A distância percorrida a pé pontua $100 \%$ e a percorrida por transporte público pontua $50 \%$. No entanto a distância que pode ser percorrida por um ônibus e o tempo que se leva para se chegar ao destino tem que ser considerado. No Marechal Tito, por exemplo, para se chegar ao centro da Cidade de São Paulo a partir do conjunto leva-se por volta de duas horas. Falta um detalhamento maior ou um complemento de tempo no caso do transporte, pois não é a mesma coisa tomar um ônibus que leva 30min para chegar a uma creche e caminhar 30min para o mesmo destino.

As subcategorias de "participação e controle" e "Educação, saúde e segurança" possuem indicadores sociais que são importantes para países em desenvolvimento.

O Atibaia $D$ atende melhor alguns itens como acessibilidade, envolvimento da comunidade local no projeto, apesar dos moradores do Marechal Tito terem liberdade para expandir o embrião como quiserem. Em termos de serviços, o Marechal Tito atende melhor o acesso aos serviços, pois vários serviços estão a menos de $400 \mathrm{~m}$ do conjunto, enquanto no Atibaia $D$ é necessário ou andar mais ou usar um meio de transporte para acessá-los.

A seguir é apresentada a categoria Economia: 
Tabela 17 Avaliação pelo SBAT - categoria economia

\begin{tabular}{|c|c|c|c|c|c|c|}
\hline & & & Mar T & & Atib & aia $D$ \\
\hline & ECONOMIA & & $\%$ & Pts & $\%$ & Pts \\
\hline EC 1 & Economia local & & & 3,0 & & 3,0 \\
\hline EC 1.1 & fornecedores locais & $\begin{array}{l}\% \text { do valor do empreendimento construído por fornecedores } \\
\text { pequenos e locais ( } 50 \mathrm{~km} \text { e <que } 20 \text { empregados) }\end{array}$ & 0 & 0,0 & 0 & 0,0 \\
\hline EC 1.2 & Materiais locais & $\%$ dos materiais que sejam provenientes de um raio de $50 \mathrm{~km}$ & 0 & 0,0 & 0 & 0,0 \\
\hline EC 1.3 & Componentes locais & $\%$ dos componentes que sejam feios no país & 100 & 1,0 & 100 & 1,0 \\
\hline EC 1.4 & Mobiliário local & \% do mobiliário que seja feito no país & 100 & 1,0 & 100 & 1,0 \\
\hline EC 1.5 & Manutenção & $\begin{array}{l}\text { \% de manutenção e reparos pelo valor que são assumidos por } \\
\text { fornecedores locais (dentro de um raio de } 50 \mathrm{~km} \text { ) }\end{array}$ & 100 & 1,0 & 100 & 1,0 \\
\hline EC 2 & Eficiência & & & 5,0 & & 5,0 \\
\hline EC 2.1 & Capacidade & $\begin{array}{l}\text { \% de áreas do empreendimento que são usadas diariamente } \\
\text { com a capacidade máxima }\end{array}$ & 100 & 1,0 & 100 & 1,0 \\
\hline EC 2.2 & Ocupação & $\%$ de tempo que o empreendimento é ocupado e usado & 100 & 1,0 & 100 & 1,0 \\
\hline EC 2.3 & Espaço por ocupante & $\begin{array}{l}\text { Espaçø previsto por usuário não pode estar } 10 \% \text { abaixo do } \\
\text { previsto para a média nacional por tipo de ocupação }\end{array}$ & 100 & 1,0 & 100 & 1,0 \\
\hline EC 2.4 & Comunicação & Empreendimento com acesso a internet e telefone & 100 & 1,0 & 100 & 1,0 \\
\hline EC 2.5 & $\begin{array}{l}\text { Materiais e } \\
\text { componentes }\end{array}$ & $\begin{array}{l}\text { Projeto executivo elaborado com a finalidade de minimizar os } \\
\text { resíduos gerados }\end{array}$ & 100 & 1,0 & 100 & 1,0 \\
\hline EC 3 & Adaptação & & & 1,0 & & 1,0 \\
\hline EC 3.1 & Alturas verticais & $\%$ dos espaços que possuem um pé direito maior ou igual a $3 \mathrm{~m}$ & 0 & 0,0 & 100 & 1,0 \\
\hline EC 3.2 & Espaço externo & $\begin{array}{l}\text { Projeto de infra-estrutura que torne o uso do espaço externo } \\
\text { flexível }\end{array}$ & 100 & 1,0 & 0 & 0,0 \\
\hline EC 3.3 & distribuição interna & Estrutura interna que seja facilmente adaptável a novos usos & 0 & 0,0 & 0 & 0,0 \\
\hline EC 3.4 & $\begin{array}{l}\text { Planejamento } \\
\text { modular }\end{array}$ & $\begin{array}{l}\text { Edificio com estrutura modular, envelope que permita fácil } \\
\text { adaptação interna }\end{array}$ & 0 & 0,0 & 0 & 0,0 \\
\hline EC 3.5 & Mobiliário & Modular, que seja facilmente adaptável para diferentes usos & 0 & 0,0 & 0 & 0,0 \\
\hline EC 4 & Custos & & & 2,0 & & 2,0 \\
\hline EC 4.1 & Indução & $\begin{array}{l}\text { Todos os novos usuários recebem treinamento sobre os } \\
\text { sistemas do emprendimento assim como um manual detalhado } \\
\text { do usuário }\end{array}$ & 0 & 0,0 & 0 & 0,0 \\
\hline EC4.2 & Consumo e descarte & $\begin{array}{l}\text { \% dos usuários que recebem informações sobre o desempenho } \\
\text { do empreendimento }\end{array}$ & 0 & 0,0 & 0 & 0,0 \\
\hline EC 4.2 & Medição & Sistema de monitoramente da água e energia bem localizado & 100 & 1,0 & 100 & 1,0 \\
\hline EC4.3 & $\begin{array}{l}\text { Manutenção e } \\
\text { limpeza }\end{array}$ & $\begin{array}{l}\text { A limpaza do edificio pode ser facilmente efetuada com } \\
\text { materiais simples e não nocivos }\end{array}$ & 100 & 1,0 & 100 & 1,0 \\
\hline SO 4.5 & Ajuda financeira & $\begin{array}{l}\% \text { ao valor de todos os materiais/ equipamentos que sao } \\
\text { diariamente usados no edifício provisionados por um fornecedor } \\
\text { local }\end{array}$ & 0 & 0,0 & 0 & 0,0 \\
\hline EC 5 & Custos de capital & & & 1,0 & & 1,0 \\
\hline EC 5.1 & Necessidades locais & $\begin{array}{l}\text { \% do capital destinado a atender necessidades locais urgentes } \\
\text { como treinamento, emprego etc durante o processo de } \\
\text { construção }\end{array}$ & 0 & 0,0 & 0 & 0,0 \\
\hline EC5.2 & Ajuda financeira & $\begin{array}{l}\text { Oferecer um pacote para a construção que assegure o } \\
\text { envolvimento de pequenos fornecedores locais }\end{array}$ & 0 & 0,0 & 0 & 0,0 \\
\hline EC 5.3 & $\begin{array}{l}\text { Custos do } \\
\text { empreendimento }\end{array}$ & $\begin{array}{l}\text { Custo do capital não deve exceder } 15 \% \text { da média nacional dos } \\
\text { empreendimentos de mesma tipologia }\end{array}$ & 100 & 1,0 & 100 & 1,0 \\
\hline EC5.4 & $\begin{array}{l}\text { Tecnologias } \\
\text { sustentáveis }\end{array}$ & $\begin{array}{l}3 \% \text { ou mais do capital destinado a novas tecnologias } \\
\text { sustentáveis }\end{array}$ & 0 & 0,0 & 0 & 0,0 \\
\hline EC 5.5 & Edificios existentes & reforma de edificios existentes & 0 & 0,0 & 0 & 0,0 \\
\hline
\end{tabular}

As subcategorias da Categoria Economia se dividem em economia local, eficiência na ocupação do espaço, adaptação do empreendimento a novos usos, custos envolvidos na manutenção e operação e custos relacionados ao investimento inicial do empreendimento. 
O sistema procura privilegiar os fornecedores locais, que de preferência estejam a uma distância de $50 \mathrm{~km}$ do empreendimento. Para uma região como São Paulo esta distância poderia até ser maior, mas para um município pequeno como Atibaia seria uma boa chance de aproveitar tanto a mão-deobra local como os fornecedores. Este indicador se encaixaria num mutirão, por exemplo, em que a mão-de-obra é local. $O$ fornecimento dos materiais no caso da CDHU, teria que vir junto com o cadastramento dos fornecedores locais no programa Qualihab.

A subcategoria referente à adaptação encontra uma alternativa para o prolongamento da vida útil do empreendimento. Um edifício com uma estrutura flexível pode ser mais facilmente adaptado a diferentes usos, prolongando sua existência. Os conjuntos podem ser ampliados, mas a estrutura, divisão de paredes não consegue ser alterada por causa do processo construtivo utilizado. É necessário quase uma reconstrução, uma grande reforma para modificação da divisão interna das unidades habitacionais.

$\mathrm{Na}$ sub-categoria Custos de Capital, apesar do conjunto possuir em projeto a instalação dos painéis solares para aquecimento da água, o valor tanto do sistema, como de instalação não foi disponibilizado, portanto não foi possível atender o indicador. A última categoria a ser apresentada é a Meio Ambiente. 
Tabela 18 Avaliação pela categoria Meio Ambiente

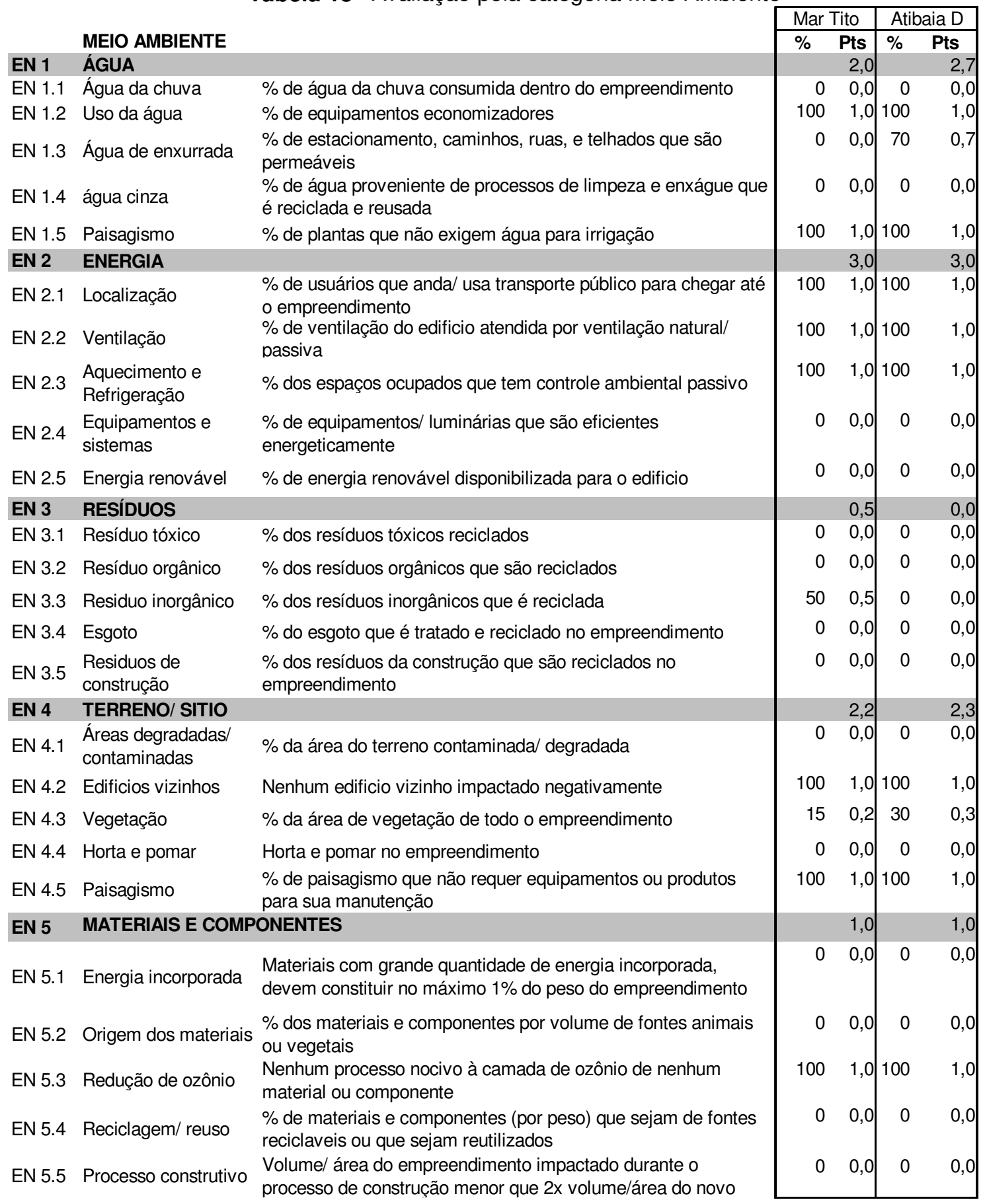

A categoria Meio Ambiente é dividida em subcategorias que correspondem à uso da água, energia, gerenciameto dos resíduos, impacto da construção e da operação do empreendimento no terreno e materiais e componentes.

Alguns indicadores do método SBAT são prescritivos: o uso de equipamentos economizadores não garante uma real economia de água e de energia. Como o consumo das famílias dos conjuntos habitacionais é muito 
baixo, os indicadores que avaliam o volume de consumo avaliam melhor do que estes prescritivos, uma vez que o custo da instalação de equipamentos economizadores é muito maior do que os tradicionais. Uma vez que a conscientização para o uso eficiente da água e da energia oferece um resultado mais efetivo.

Os indicadores referentes ao paisagismo foram atendidos nos dois empreendimentos por motivos diferentes: no caso do Marechal Tito, não existe um plano ou planejamento para as áreas verdes, elas simplesmente estão lá. No caso do Atibaia $D$, existe um plano cuidadoso, resta saber se será realmente operado conforme previsto em projeto.

Para avaliação pelo método faltam dados para atendimento aos indicadores, como por exemplo: quantidade de energia incorporada nos materiais, origem dos materiais. Também não há preocupação com 0 tratamento e reuso da água cinza ou armazenamento da água pluvial.

O resultado dos dois conjuntos pode ser visualizado nos gráficos apresentados a seguir: 


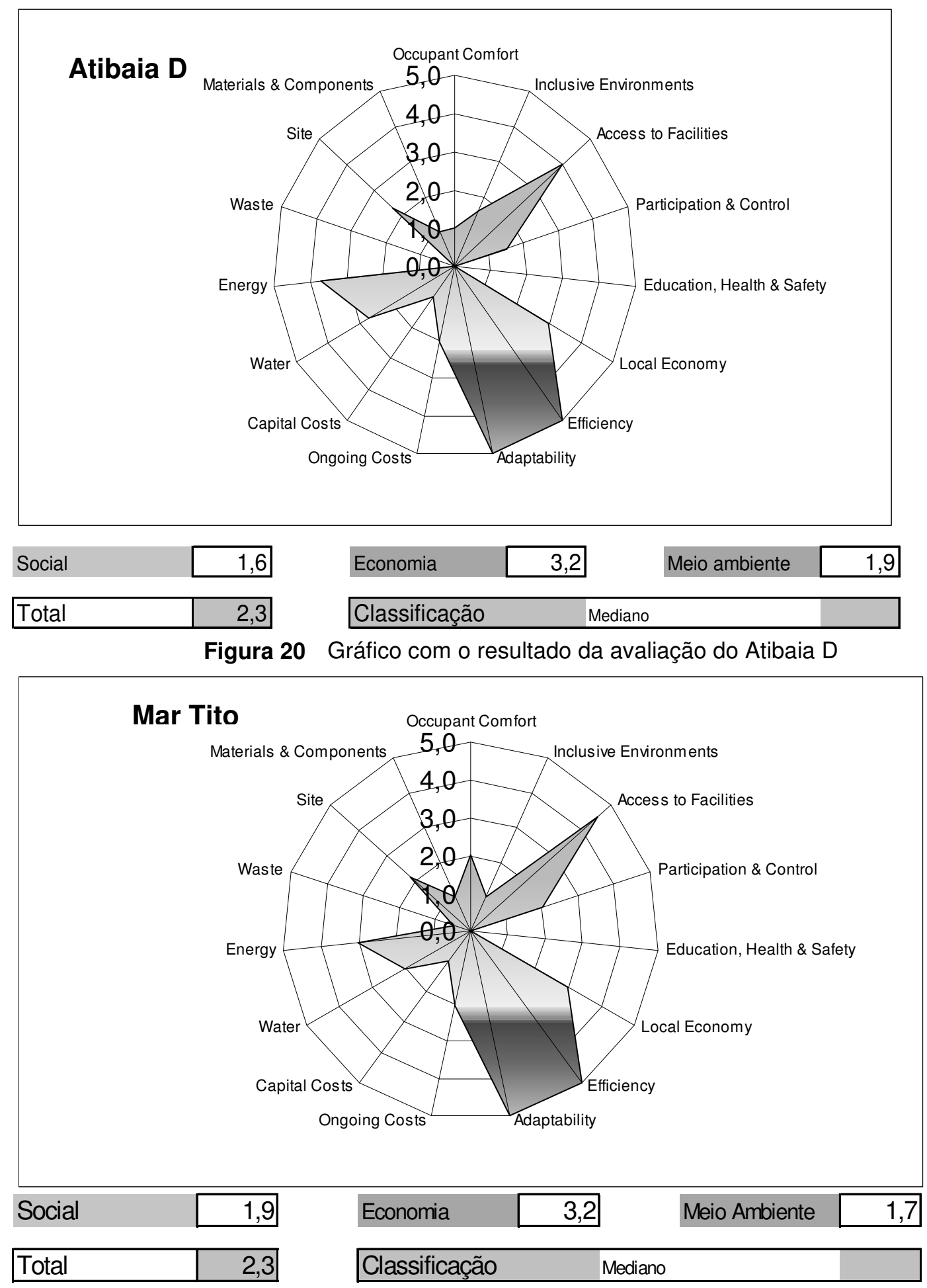

Figura 21 Gráfico com a avaliação do Marechal Tito

A diferença entre os dois conjuntos é pequena, o desempenho na categoria meio ambiente foi melhor no Atibaia $\mathrm{D}$, a categoria social apresentou um desempenho melhor no Marechal Tito e a categoria economia apresentou 
avaliação igual nos dois. Uma dificuldade enfrentada pelo método foi traduzir os resultados em porcentagens. Isso torna a avaliação dos empreendimentos pelo o método um pouco subjetiva, um indicador pode ter um desempenho melhor ou não dependendo do avaliador.

\subsection{AVALIAÇÃO PELO SBTOOL (ANTIGO GBTOOL)}

O SBTool foi o sistema mais trabalhoso, complexo e difícil dos cinco escolhidos para a avaliação dos conjuntos. A partir de janeiro de 2007, quando a primeira versão foi lançada, surgiu quase uma nova versão a cada mês. $A$ versão utilizada neste trabalho foi uma versão de agosto de 2008.

O sistema, no geral, é extremamente complexo, mas também flexível. A última versão usada foi recebida em agosto. O sistema oferece uma opção para usar a ponderação padrão do SBTool ou utilizar seus próprios valores. Foi escolhida esta última apesar de inúmeras tentativas para se utilizar todas. $\mathrm{Na}$ verdade os pesos das categorias não foram alterados, somente foram desligadas duas categorias; e os pesos foram redistribuídos automaticamente. Para a avaliação dos conjuntos foram desligadas: três subcategorias da área consumo de energia e recursos, a categoria qualidade do ambiente interno e a categoria qualidade dos serviços, por falta de informação a ser fornecida para a avaliação do método.

O sistema não funciona, por exemplo, como o Ecohomes, que, dentre as opções entre os indicadores, há também a opção "não atende" que é o zero. No SBTool, o zero é um padrão, e na ponderação final, ele pontua. Apesar deste fato, todas as planilhas do programa Excel têm vínculos entre si e muitas das avaliações já são automáticas. São avaliações que vão sendo realizadas conforme se dá o preenchimento de dados nas planilhas iniciais. Muitos desses dados são relativos à análise do ciclo de vida dos materiais constituintes da edificação e essa análise está começando a ser praticada agora no Brasil.

É importante lembrar que durante todo o processo de avaliação das diferentes versões, tentou-se de todos os modos avaliar os conjuntos por todos 
os indicadores, mas num determinado momento havia algum fator que inviabilizava a avaliação completa. Existe a consciência de que se os outros indicadores e categorias estivessem ativados a avaliação poderia ser completamente diferente, mas infelizmente devido à quantidade de informação inexistente, preferiu-se desativar estes indicadores a fornecer qualquer informação relacionada à prática insatisfatória, correspondente a -1.

O sistema de avaliação apresenta um outro fator limitante: é o fato dele ter sido desenvolvido em programa Excel e possuir várias planilhas vinculadas entre si. A principal dificuldade é que de um computador para o outro ou de uma versão mais nova para uma mais antiga, não somente do software, mas também do Windows toda configuração inicial dos pesos é modificada e isso interfere diretamente no resultado final. Além disso, muitas vezes não se percebe que os pesos mudaram.

Tabela 19 Tabela mostra o peso das categorias para a avaliação dos conjuntos.

\begin{tabular}{|c|c|c|c|c|c|}
\hline \multirow{2}{*}{\multicolumn{3}{|c|}{$\begin{array}{c}\text { Weighting of Issues and Categories for Atibaia, } \\
\text { Brasil }\end{array}$}} & \multicolumn{3}{|c|}{ Design Phase } \\
\hline & & & \multicolumn{3}{|c|}{ Generic } \\
\hline $\begin{array}{l}\text { Values range from } 0 \text { (not applicable) to } 5 \text { (most important), with the value } 2 \\
\text { representing the normal default or null value, except for Mandatory parameters, } \\
\text { which range from } 3 \text { to } 5 \text {. } \\
\text { Click on box at right to select Default or your own weighting values. }\end{array}$ & \multicolumn{5}{|c|}{ Use your values } \\
\hline $\begin{array}{l}\text { Instructions: } \\
\text { First decide if you want to use the defaults } \\
\text { If you want to set your own weights } \\
\text { 1. First set relative importance for highest level Issues } \\
\text { 2. Then set values for Categories within each Issue area } \\
\text { 3. To set lowest level weights, go to WtB }\end{array}$ & $\begin{array}{l}\text { Suggested } \\
\text { nominal } \\
\text { default } \\
\text { values. }\end{array}$ & $\begin{array}{l}\text { Nominal } \\
\text { weights } \\
\text { adjusted for } \\
\text { number of } \\
\text { active } \\
\text { Categories }\end{array}$ & $\begin{array}{c}\text { Weighted } \\
\text { percent }\end{array}$ & $\begin{array}{l}\text { Select your } \\
\text { own } \\
\text { nominal } \\
\text { weighting } \\
\text { values }\end{array}$ & $\begin{array}{l}\frac{7}{0} \\
\frac{0}{\pi} \\
\frac{\pi}{0} \\
\frac{\pi}{2} \\
\sum\end{array}$ \\
\hline \multicolumn{3}{|l|}{ Issues } & \multicolumn{3}{|c|}{ Active } \\
\hline A Site Selection, Project Planning and Development & 3 & 1,3 & $13,8 \%$ & 3 & \\
\hline B Energy and Resource Consumption & 5 & 2,9 & $30,8 \%$ & 4 & \\
\hline C Environmental Loadings & 5 & 4,3 & $46,2 \%$ & 5 & \\
\hline D Indoor Environmental Quality & 4 & 0,0 & $0,0 \%$ & 0 & \\
\hline E Service Quality & 3 & 0,0 & $0,0 \%$ & 0 & \\
\hline $\mathrm{F}$ Social and Economic aspects & 3 & 0,6 & $6,2 \%$ & 2 & \\
\hline G Cultural and Perceptual Aspects & 3 & 0,3 & $3,1 \%$ & 2 & \\
\hline
\end{tabular}

A tabela 19 mostra a planilha WtA do sistema onde é feita a ponderação dos pesos das categorias. A figura apresentada corresponde ao Atibaia D mas foi usada a mesma configuração para o conjunto Marechal Tito também.

O valor dos pesos pode ser ajustado de 0 a 5 e nas categorias 
obrigatórias de 3 a 5.

Os indicadores usados nesta versão do sistema são apresentados a seguir. Os ativados possuem um valor nos pesos especificados e os desativados com os valores iguais a zero. A primeira coluna de porcentagens apresenta o peso do indicador no grupo e a segunda, o peso do indicador no sistema geral. A porcentagem ao lado da categoria indica o quanto ela pesa no sistema geral.

Tabela 20 Avaliação pela primeira categoria do SBTool

\begin{tabular}{|c|c|c|c|c|}
\hline \multirow{2}{*}{\multicolumn{3}{|c|}{ Indicadores para avaliação dos conjuntos }} & \multirow{3}{*}{$\begin{array}{r}\begin{array}{r}\text { Marechal } \\
\text { tito }\end{array} \\
0,23 \\
\end{array}$} & \multirow{3}{*}{$\begin{array}{r}\text { Atibaia D } \\
0,33 \\
\end{array}$} \\
\hline & & & & \\
\hline A & \multicolumn{2}{|c|}{ Seleção do terreno, planejamento e desenvolvimento do projeto } & & \\
\hline A1 & \multicolumn{2}{|c|}{ Seleção do terreno } & 1,26 & 0,76 \\
\hline & A1.3 & Vulnerabilidade à inundação & 0,28 & 0,28 \\
\hline & A1.4 & Potencial para contaminação de corpos d'água próximos & 1,22 & 0,12 \\
\hline & A1.5 & Recuperação de áreas contaminadas & 0,00 & 0,00 \\
\hline & A1.6 & Proximidade de transporte público & 0,81 & 0,81 \\
\hline & A1.7 & Distancia entre os empreendimento e os centros de emprego & 0,81 & 0,81 \\
\hline & A1.8 & Proximidade de serviços comerciais e culturais & 0,27 & 0,27 \\
\hline & A1.9 & Proximidade de áreas de recreação e lazer & 0,27 & 0,22 \\
\hline $\mathrm{A} 2$ & \multicolumn{2}{|c|}{ Planejamento do empreendimento } & 0,01 & 0,96 \\
\hline & A2.1 & Possibilidade dos uso de renováveis & $-0,10$ & $-0,10$ \\
\hline & A2.2 & Uso do processo Integrado de Projeto & $-0,10$ & 0,30 \\
\hline & A2.3 & Estudo de impacto ambiental para o empreendimento & $-0,20$ & 0,80 \\
\hline & A2.4 & Provisão de um sistema de água de superfície & $-0,13$ & 0,00 \\
\hline & A2.5 & Disponibilidade de um sistema de tratamento da água servida & 0,50 & 0,50 \\
\hline & A2.6 & Disponibilidade de separação entre o sistema de água potável e água cinza & $-0,07$ & 0,07 \\
\hline & A2.7 & Coleta e reciclagem dos resíduos sólidos na comunidade ou empreendimento & 0,00 & 0,27 \\
\hline & A2.8 & Tratamento ou reuso do esgoto na comunidade ou no empreendimento & $-0,13$ & 0,67 \\
\hline & A2.9 & Orientação do empreendimento para maximizar o potencial solar & 0,25 & 0,40 \\
\hline \multirow[t]{10}{*}{ A3 } & \multicolumn{2}{|r|}{ Desenho urbano e desenvolvimento do empreendimento } & 0,42 & 0,68 \\
\hline & A3.1 & Desenvolviemnto da densidade & $-0,09$ & $-0,09$ \\
\hline & A3.2 & Provisão de um sistema de água de superfície & 0,00 & 0,00 \\
\hline & A3.3 & Incentivo ao deslocamento à pé & 0,00 & 0,87 \\
\hline & A3.4 & Apoio para o uso da bicicleta & $-0,12$ & $-0,12$ \\
\hline & A3.5 & Diretrizes para o uso de automóveis privados & 0,65 & 0,20 \\
\hline & A3.6 & Provisão de áreas verdes & 0,87 & 0,87 \\
\hline & A3.7 & Uso de espécies nativas & $-0,02$ & 0,14 \\
\hline & A3.8 & Provisão de árvores com capacidade de sombreamento & 0,05 & 0,35 \\
\hline & A3.9 & Desenvolvimento e manutenção de corredores ecológicos & 0,00 & 0,00 \\
\hline
\end{tabular}

Os dois conjuntos são bem avaliados nos itens referentes a desenho urbano, localização e proximidade de serviços, embora o peso na pontuação geral desta categoria seja muito pequeno, apenas $13,8 \%$ do valor total na 
configuração que foi adotada.

Tabela 21 Avaliação pela categoria consumo de energia e recursos

\begin{tabular}{|c|c|c|c|c|}
\hline & & Indicadores para avaliação dos conjuntos & $\begin{array}{r}\text { Marechal } \\
\text { tito }\end{array}$ & tibaia $D$ \\
\hline B & Consu & mo de energia e recursos & 0,19 & 0,37 \\
\hline B1 & Energic & a total não renovável durante o ciclo de vida & 0,00 & 0,00 \\
\hline & B1.1 & Energia não-renovável incorporada nos materiais de construção & 0,00 & 0,00 \\
\hline & B1.2 & Energia não-renovável usada para a operação do empreendimento & 0,00 & 0,00 \\
\hline $\mathrm{B} 2$ & Pico de & demanda de energia para operação e manutenção & 0,00 & 0,00 \\
\hline B3 & Energi & a renovável & 0,00 & 0,00 \\
\hline & B3.1 & Uso de energia renovável fora do empreendimento que provém de fontes renováveis & 0,00 & 0,00 \\
\hline & B3.2 & Provisão de sistemas gerados de energia renovável no empreendimento & 0,00 & 0,00 \\
\hline B4 & Mateira & & 0,0 & \\
\hline & B4.1 & Reuso de estrutura existente & 0,00 & 0,00 \\
\hline & B4.2 & Uso mínimo de materiais de acabamento & 0,00 & 0,00 \\
\hline & B4.3 & Uso mínimo de materiais virgens & 0,00 & 0,00 \\
\hline & B4.4 & Uso de materiais duráveis & 0,00 & 0,00 \\
\hline & B4.5 & Reuso de materiais reciclados & 0,00 & 0,00 \\
\hline & B4.6 & Uso de materiais reciclados provenientes de fora do empreendimento & 0,00 & 0,00 \\
\hline & B4.7 & Uso de produtos bio-based provenientes de fornecedores ou fontes sustentáveis & 0,00 & 0,00 \\
\hline & B4.8 & Uso de materiais suplementares no concreto & 0,00 & 0,00 \\
\hline & B4.9 & Uso de materiais que são produzidos localmente & 0,00 & 0,00 \\
\hline & B4.10 & Projeto para disposição, desmontagem reuso ou reciclagem & 0,00 & 0,00 \\
\hline B5 & Água $\mathrm{p}$ & otável & 0,60 & 1,21 \\
\hline & B5.1 & Uso de água potável para irrigação & 0,94 & 0,94 \\
\hline & B5.2 & Uso de água potável para necessidades do empreendimento e da ocupação & $-0,33$ & 0,27 \\
\hline
\end{tabular}

Na categoria "Consumo de recursos e energia", só foi possível avaliar os itens relacionados à água. Os itens relacionados à energia foram desativados, por falta de dados para atender ao indicador. A maior parte dos consumidores do país adquire energia da rede principal que é composta em grande parte pela energia de hidrelétricas e uma pequena parte por termelétricas, mas que são misturadas na rede e não existe uma diferenciação de que parte se consome de quem. O mercado de energia brasileiro não é aberto, existem restrições e os consumidores brasileiros não são livres para comprar a energia de onde querem, existem regras para o mercado de energia de fontes alternativas de forma que não é tão simples adquiri-la, principalmente para pequenos consumidores.

Um outro motivo pelo qual não foi possível é que esta quantidade de 
energia é obtida pela avaliação do ciclo de vida dos materiais, uma avaliação que não é ainda muito comum no Brasil.

Os itens relacionados aos materiais não foram avaliados, porque não se teve acesso a dados como orçamento de obra, memorial descritivo etc. de forma que só seria possível uma avaliação superficial que não teria muito fundamento, por exemplo, de um lado, sabe-se que a grande parte dos materiais era nova, não reciclados, de outro também é conhecido que foi utilizado um tipo de cimento, mas não se sabia que tipo de cimento, se CPII ou CPIII, que possuem em sua composição uma grande quantidade de material reciclado.

A próxima categoria, "cargas ambientais", avalia os impactos do empreendimento no meio ambiente levando em conta indicadores como emissões de gases de efeito estufa e outras emissões atmosféricas, água, impacto da construção no terreno. Por falta de dados, foram desativadas as subcategorias emissões $-\mathrm{C} 1, \mathrm{C} 2$.

A questão das águas deste item também foi desligada. Nos conjuntos habitacionais avaliados não há qualquer menção feita ao aproveitamento da água da chuva, no caso do Atibaia $\mathrm{D}$, ele tem uma área permeável um pouco maior que o convencional, Marechal Tito, mas o resuso não foi considerado como diretriz de projeto.

Dessa maneira permaneceram as subcategorias: "resíduos sólidos", "impactos no empreendimento" e "outros impactos regionais e locais". Os indicadores referentes a cada subcategoria, assim como os pesos podem ser observados na tabela 22 , a seguir: 
Tabela 22 Avaliação pela categoria cargas ambientais

\begin{tabular}{|c|c|c|c|c|}
\hline & & Indicadores para avaliação dos conjuntos & $\begin{array}{r}\text { Marechal } \\
\text { tito }\end{array}$ & Atibaia D \\
\hline $\mathrm{C}$ & Carga & s ambienteais & 0,36 & 0,95 \\
\hline $\mathrm{C} 1$ & Emiss & o de gases de efeito estufa & 0,00 & \\
\hline & $\mathrm{C} 1.1$ & Emissão de GHG incorporados nos materiais de construção & 0,00 & 0,00 \\
\hline & C1.2 & $\begin{array}{l}\text { Emissão de GHG proveniente de toda a energia usada para a operação do } \\
\text { empreendimento }\end{array}$ & 0,00 & 0,00 \\
\hline $\mathrm{C} 2$ & Outras & emissões atmosféricas & 0,00 & \\
\hline & $\mathrm{C} 2.1$ & $\begin{array}{l}\text { Emissão de substâncias nocivas à camada de ozônio durante a operação do } \\
\text { empreendimento }\end{array}$ & 0,00 & 0,00 \\
\hline & $\mathrm{C} 2.2$ & Emissões ácidas durante a operação & 0,00 & 0,00 \\
\hline & $\mathrm{C} 2.3$ & Emissões que levam a foto-oxidantes, durante a operação & 0,00 & 0,00 \\
\hline $\mathrm{C} 3$ & Resídu & IOS sólidos & $-0,15$ & $-0,19$ \\
\hline & C3.1 & Resíduos sólidos resultante do processo de demolição e construção & $-0,60$ & $\overline{-0,24}$ \\
\hline & C3.2 & Resíduos sólidos provenientes da operação, manutenção & $-0,40$ & $-0,60$ \\
\hline $\mathrm{C} 4$ & Água c & a chuva, água dispensada ou água de enxurrada & 0,00 & \\
\hline & C4.1 & $\begin{array}{l}\text { Efluentes líquidos liberados para fora do empreendimento resultantes da operação } \\
\text { do empreendimento }\end{array}$ & 0,00 & 0,00 \\
\hline & C4.2 & Retenção de água da chuva para posterior reuso & 0,00 & 0,00 \\
\hline & C4.3 & Água de enxurrada retida no empreendimento & 0,00 & 0,00 \\
\hline C5 & Impact & os no empreendimento & 0,08 & 1,11 \\
\hline & C5.1 & Impacto do processo de construção nas características naturais do terreno & 0,47 & 0,56 \\
\hline & C5.2 & Impacto do processo de construção na paisagem ou na erosão do solo & $-0,13$ & 0,00 \\
\hline & C5.3 & Mudanças na biodiversidade do terreno & 0,00 & 2,81 \\
\hline & C5.5 & Minimização do impacto de contaminantes no terreno & $-0,13$ & $-0,13$ \\
\hline C6 & Outros & impactos locais e regionais & 0,85 & 1,13 \\
\hline & C6.1 & Impacto no acesso à luz do dia ou energia solar das propriedades vizinhas & 1,96 & 1,96 \\
\hline & C6.2 & Mudanças termais cumulativas em lagos ou aquiferos & 0,00 & 0,00 \\
\hline & C6.3 & Ilha de calor - paisagem e áreas pavimentadas & $-0,26$ & 0,25 \\
\hline & C6.4 & Ilha de calor -cobertura & 0,00 & 0,00 \\
\hline & C6.5 & Poluição luminosa & 0,29 & 0,43 \\
\hline
\end{tabular}

Foi possível avaliar os conjuntos porque o sistema pede para estas subcategorias, por exemplo, se houve o desenvolvimento de um plano que assegurasse que o processo de construção e operação não alteraria as características do terreno, ou ainda que o empreendimento melhorasse ou fosse indiferente ao valor ecológico anterior. O desempenho do Atibaia $D$ nesta categoria foi um pouco melhor que o Marechal Tito.

As categorias seguintes "qualidade do ambiente interno" e "qualidade de serviços" avaliam principalmente a fase de construção e manutenção do empreendimento e avaliam melhor os empreendimentos comerciais, edifício de escritórios etc. Apesar do peso delas ser zero na avaliação utilizada nos 


\section{conjuntos seus indicadores são apresentados na tabela 8:}

Tabela 23 As categorias foram desativadas, nenhum dos dois conjuntos foi avaliado por elas

\begin{tabular}{|c|c|c|c|c|}
\hline & & Indicadores para avaliação dos conjuntos & $\begin{array}{r}\text { Marechal } \\
\text { tito }\end{array}$ & Atibaia $D$ \\
\hline D & Qualic & ade do ambiente interno & 0,00 & \\
\hline D1 & Qualid & ade do ar interno & 0,00 & \\
\hline & D1.1 & Proteção dos materiais durante a fase de construção & 0,00 & 0,00 \\
\hline & D1.2 & Remoção, antes da ocupação, de poluentes emitidos por materiais de acabamento & 0,00 & 0,00 \\
\hline & D1.3 & Materiais de acabamento com baixa emissão de COVs. & 0,00 & 0,00 \\
\hline & D1.4 & Migração de poluentes entre diferentes ocupações & 0,00 & 0,00 \\
\hline & D1.5 & Poluentes gerados por atividades de manutenção & 0,00 & 0,00 \\
\hline & D1.6 & Poluentes gerados por ocupação (fumaça gerada pelo tabagismo) & 0,00 & 0,00 \\
\hline & D1.7 & Concentrações de $\mathrm{CO} 2$ no ar interno & 0,00 & 0,00 \\
\hline$\overline{\mathrm{D} 2}$ & Ventila & ção & 0,00 & \\
\hline & $\mathrm{D} 2.1$ & Eficiência da ventilação natural & 0,00 & 0,00 \\
\hline & D2.2 & Qualidade do ar eventilação em espaços ventilados mecanicamente & 0,00 & 0,00 \\
\hline & $\mathrm{D} 2.3$ & Movimento do ar em espaços mecanicamente ventilados & 0,00 & 0,00 \\
\hline D3 & Tempe & ratura do ar e humidade relativa & 0,00 & \\
\hline & D3.1 & Temperatura do ar e humidade relativa em ambientes refrigerados & 0,00 & 0,00 \\
\hline & D3.2 & Temperatura do ar em ambiente naturalmente ventilados & 0,00 & 0,00 \\
\hline $\mathrm{D} 4$ & Ilumin & ção natural e artificial & 0,00 & \\
\hline & D4.1 & Fator de luz do dia nos ambientes & 0,00 & 0,00 \\
\hline D5 & Ruído & e acústica & 0,00 & \\
\hline & D5.1 & Atenuação do ruído pelo envelope & 0,00 & 0,00 \\
\hline & D5.2 & Transmissão do ruído da operação para os ambientes & 0,00 & 0,00 \\
\hline & D5.3 & Isolamento acústico entre os ambientes do empreendimento & 0,00 & 0,00 \\
\hline E & Qualic & ade dos serviços & 0,00 & \\
\hline E1 & Segur & Inça durante a operação & 0,00 & \\
\hline & E1.6 & Manutenção das principais atividades do empreendimento durante falta de energia & 0,00 & 0,00 \\
\hline E2 & Eficiên & cia e funcionalidade & 0,00 & \\
\hline & E2.5 & Eficiência espacial & 0,00 & 0,00 \\
\hline & E2.6 & Eficiência volumétrica & 0,00 & 0,00 \\
\hline E3 & Contro & & 0,00 & \\
\hline & E3.1 & Provisão e operação de um efetivo sistema de controle da operação & 0,00 & 0,00 \\
\hline & E3.2 & Capacidade para operação & 0,00 & 0,00 \\
\hline & E3.4 & Grau de controle pessoal dos sistemas pelos ocupantes & 0,00 & 0,00 \\
\hline E4 & Flexibi & idade e adaptabilidade & 0,00 & \\
\hline & E4.1 & Possibilidade de modificar os sistemas de operação & 0,00 & 0,00 \\
\hline & E4.2 & Capacidade da estrutura do empreendimento na adaptação a diferentes usos & 0,00 & 0,00 \\
\hline & E4.3 & Limitação imposta pela altura do pé-direito nas edificações & 0,00 & 0,00 \\
\hline & E4.4 & Limitação imposta pelo envelope e pelas instalações prediais & 0,00 & 0,00 \\
\hline & E4.5 & Capacidade de adaptação a futuras mudanças no suprimento de energia & 0,00 & 0,00 \\
\hline E5 & Comis & ionamento dos sistemas de operação & 0,00 & \\
\hline E6 & Desem & penho da operação e manutenção & 0,00 & \\
\hline & E6.1 & Manutenção para bom desempenho do envelope & 0,00 & 0,00 \\
\hline & E6.2 & Uso de materiais duráveis & 0,00 & 0,00 \\
\hline & E6.3 & Desenvolvimento e implantação de um plano de gerenciamento da manutenção & 0,00 & 0,00 \\
\hline & E6.4 & Monitoramento e manutenção contínua do desempenho & 0,00 & 0,00 \\
\hline & E6.5 & Disponibilidade de as-builts atualizados & 0,00 & 0,00 \\
\hline & E6.6 & Provisão e manutenção de um diário do empreendimento & 0,00 & 0,00 \\
\hline & E6.7 & Acordos de vendas ou locação que garantam boa operação por parte dos locatários & 0,00 & 0,00 \\
\hline & E6.8 & Conhecimento e habilidades da equipe de operação e manutenção & 0,00 & 0,00 \\
\hline
\end{tabular}


As categorias a seguir "Aspectos econômicos e sociais" e "aspectos culturais" avaliam a parte social do empreendimento. Para os dois conjuntos a subcategoria: "custos e economia" foi desligada pois não se teve acesso aos custos dos projetos. Apesar de alguns indicadores apresentarem possibilidade de serem aplicados aos conjuntos.

Tabela 24 Avaliação pela categoria aspectos sociais e culturais, os econômicos não foram considerados na avaliação

\begin{tabular}{|c|c|c|c|c|}
\hline \multicolumn{3}{|r|}{ Indicadores para avaliação dos conjuntos } & \multirow{2}{*}{$\begin{array}{r}\begin{array}{r}\text { Marechal } \\
\text { tito }\end{array} \\
0,06 \\
\end{array}$} & \multirow{2}{*}{$\begin{array}{r}\text { Atibaia } \\
\quad 0,25\end{array}$} \\
\hline$F$ & Aspec & tos econômicos e sociais & & \\
\hline \multirow[t]{7}{*}{$\mathrm{F} 1$} & \multicolumn{2}{|c|}{ Aspectos sociais } & 0,95 & 4,08 \\
\hline & $\mathrm{F} 1.1$ & Minimização dos acidentes durante a construção & $-0,14$ & 0,71 \\
\hline & $\mathrm{F} 1.2$ & Acessibilidade a pessoas com dificuldade de locomoção & $-0,29$ & 2,14 \\
\hline & $\mathrm{F} 1.3$ & Incidência da luz solar nos ambientes das unidades habitacionais & 0,71 & 0,71 \\
\hline & $\mathrm{F} 1.4$ & Unidades habitacionais com acesso a espaços privados & 0,71 & 0,56 \\
\hline & $\mathrm{F} 1.5$ & Garantia da privacidade visual dentro das principais unidade habitacionais & $-0,05$ & $-0,05$ \\
\hline & $\mathrm{F} 1.7$ & Impacto social positivo do empreendimento na região & 0,00 & 0,00 \\
\hline \multirow[t]{6}{*}{$\mathrm{F} 2$} & \multicolumn{2}{|c|}{ Custos e economia } & \multicolumn{2}{|l|}{0,00} \\
\hline & F2.1 & Minimização do custo do ciclo de vida & 0,00 & 0,00 \\
\hline & $\mathrm{F} 2.2$ & Minimização do custo da construção & 0,00 & 0,00 \\
\hline & F2.3 & Minimização dos custos de operação e manutenção & 0,00 & 0,00 \\
\hline & $\mathrm{F} 2.4$ & Custos acessíveis a aluguel e vendas & 0,00 & 0,00 \\
\hline & F2.5 & Apoio à economia local & 0,00 & 0,00 \\
\hline G & \multicolumn{2}{|c|}{ Aspectos culturais } & 0,12 & 0,13 \\
\hline \multirow[t]{4}{*}{$\mathrm{G} 1$} & \multicolumn{2}{|c|}{ Cultura e Patrimônio } & 4,00 & 4,25 \\
\hline & G1.1 & Relação do projeto com a paisagem urbana existente & 2,50 & 2,50 \\
\hline & $\mathrm{G} 1.2$ & Compatibilidade entre o desenho urbano e os valores locais & 1,50 & 1,75 \\
\hline & G1.3 & Manutenção do patrimônio existente & 0,00 & 0,00 \\
\hline
\end{tabular}

Os conjuntos apresentaram um bom desempenho tanto na subcategoria dos aspectos sociais como na dos culturais. Cada conjunto tem uma boa relação com seu entorno.

O resultado final é apresentado exatamente como no método de avaliação, primeiro para o Conjunto Marechal Tito e após para o conjunto Atibaia D.: 
Figura 22 resultado final para o conjunto Marechal Tito

\begin{tabular}{|c|c|c|c|c|}
\hline Assessment Scores for Marech & al Tito H1, São F & Paulo, & Brasil & \\
\hline $\begin{array}{l}\text { Predicted performance results based on } \\
\text { information available during Design Phase }\end{array}$ & $\begin{array}{r}\text { Active Phase } \\
\text { (set in Region file) }\end{array}$ & \multicolumn{3}{|c|}{ Design Phase } \\
\hline Relative Performance Results & \multicolumn{4}{|c|}{ Project Information } \\
\hline \multirow[b]{12}{*}{ Per } & \multicolumn{4}{|c|}{$\begin{array}{l}\text { This is a New construction project with a total gross area of } 11980 \mathrm{~m} 2 . \\
\text { It has an estimated lifespan of } 75 \text { years, and contains the following } \\
\text { occupancies: Attached housing and Outdoor area and is located in São } \\
\text { Paulo, Brasil. The assessment is valid for the Design Phase. }\end{array}$} \\
\hline & $\begin{array}{l}\text { Assumed life span is } 75 \text { years, and } \\
\text { monetary units are in } 0\end{array}$ & \multicolumn{3}{|c|}{$\begin{array}{l}\text { Amortization rate for embodied energy of } \\
\text { existing materials is set at } 0 \%\end{array}$} \\
\hline & $\begin{array}{l}\text { The project contains } 148 \\
\text { apartment units }\end{array}$ & \multicolumn{3}{|c|}{ Assessment Scores } \\
\hline & $\begin{array}{r}\text { With current context and building data, } \\
\text { the number of active low-level } \\
\text { parameters is: }\end{array}$ & 44 & $\begin{array}{r}\text { Max. potential } \\
\text { low-level } \\
\text { parameters: }\end{array}$ & 110 \\
\hline & $\begin{array}{r}\text { The number of active low-leve } \\
\text { mandatory parameters with a score of } \\
\text { less than } 2 \text { is: }\end{array}$ & -1 & $\begin{array}{r}\text { Active low-level } \\
\text { mandatory } \\
\text { parameters: }\end{array}$ & 0 \\
\hline & \multicolumn{2}{|c|}{$\begin{array}{r}\text { To see a full list of Issues, Categories and Criteria, go } \\
\text { to the Issues worksheet. }\end{array}$} & $\begin{array}{l}\text { Active } \\
\text { Weights }\end{array}$ & $\begin{array}{l}\text { Weighted } \\
\text { scores }\end{array}$ \\
\hline & \multicolumn{2}{|c|}{$\begin{array}{l}\text { A Site Selection, Project Planning and } \\
\text { Development }\end{array}$} & $14 \%$ & 1,7 \\
\hline & \multicolumn{2}{|c|}{ B Energy and Resource Consumption } & $31 \%$ & 0,6 \\
\hline & \multicolumn{2}{|l|}{ C Environmental Loadings } & $46 \%$ & 0,8 \\
\hline & \multicolumn{2}{|l|}{ D Indoor Environmental Quality } & $0 \%$ & 0,0 \\
\hline & \multicolumn{2}{|l|}{ E Service Quality } & $0 \%$ & 0,0 \\
\hline & \multicolumn{2}{|l|}{ F Social and Economic aspects } & $6 \%$ & 1,0 \\
\hline \multirow{2}{*}{$\begin{array}{l}\text { Design Phase scores indicate Potential Performance as predicted by an assessment } \\
\text { of building features and plans for construction and operation that are developed } \\
\text { during the design process. }\end{array}$} & \multicolumn{2}{|c|}{ G Cultural and Perceptual Aspects } & $3 \%$ & 4,0 \\
\hline & \multicolumn{3}{|c|}{ Total welghted building score } & 1,0 \\
\hline
\end{tabular}

A figura 22 apresenta o resultado final da avaliação do Marechal Tito pelo SBTool. A pontuação geral do conjunto foi bem baixa, apesar da avaliação final ter ficado entre a prática aceitável e a boa prática, vale lembrar que duas categorias inteiras não foram consideradas e algumas outras subcategorias também não, talvez a pontuação final ficasse ainda mais caso estas categorias ainda fossem consideradas. A avaliação pelo Atibaia $D$ é apresentada a seguir: 
Figura 23 resultado final para o conjunto Atibaia $D$

\begin{tabular}{|c|c|c|c|c|}
\hline Assessment Scores for A & tibaia D, Atibaia, & Brasil & & \\
\hline $\begin{array}{l}\text { Predicted performance results based on } \\
\text { information available during Design Phase }\end{array}$ & $\begin{array}{r}\text { Active Phase } \\
\text { (set in Region file) }\end{array}$ & \multicolumn{3}{|c|}{ Design Phase } \\
\hline Relative Performance Results & \multicolumn{4}{|c|}{ Project Information } \\
\hline \multirow[b]{12}{*}{ Performance Iss } & \multicolumn{4}{|c|}{$\begin{array}{l}\text { This is a New construction project with a total gross area of } 19620 \mathrm{~m} 2 . \\
\text { It has an estimated lifespan of } 75 \text { years, and contains the following } \\
\text { occupancies: Attached housing and Attached housing and is located in } \\
\text { Atibaia, Brasil. The assessment is valid for the Design Phase. }\end{array}$} \\
\hline & $\begin{array}{l}\text { Assumed life span is } 75 \text { years, and } \\
\text { monetary units are in Real }\end{array}$ & \multicolumn{3}{|c|}{$\begin{array}{l}\text { Amortization rate for embodied energy of } \\
\text { existing materials is set at } 5 \%\end{array}$} \\
\hline & $\begin{array}{l}\text { The project contains } 148 \\
\text { apartment units }\end{array}$ & \multicolumn{3}{|c|}{ Assessment Scores } \\
\hline & $\begin{array}{r}\text { With current context and building data, } \\
\text { the number of active low-level| } \\
\text { parameters is: }\end{array}$ & 44 & $\begin{array}{r}\text { Max. potential } \\
\text { low-level } \\
\text { parameters: }\end{array}$ & 110 \\
\hline & $\begin{array}{r}\text { The number of active low-level| } \\
\text { mandatory parameters with a score of } \\
\text { less than } 2 \text { is: }\end{array}$ & -1 & $\begin{array}{r}\text { Active low-level } \\
\text { mandatory } \\
\text { parameters: }\end{array}$ & 0 \\
\hline & \multicolumn{2}{|c|}{$\begin{array}{r}\text { To see a full list of Issues, Categories and Criteria, go } \\
\text { to the Issues worksheet. }\end{array}$} & $\begin{array}{l}\text { Active } \\
\text { Weights }\end{array}$ & $\begin{array}{l}\text { Weighted } \\
\text { scores }\end{array}$ \\
\hline & \multicolumn{2}{|c|}{$\begin{array}{l}\text { A Site Selection, Project Planning and } \\
\text { Development }\end{array}$} & $14 \%$ & 2,4 \\
\hline & \multicolumn{2}{|c|}{ B Energy and Resource Consumption } & $31 \%$ & 1,2 \\
\hline & \multicolumn{2}{|l|}{ C Environmental Loadings } & $46 \%$ & 2,1 \\
\hline & \multicolumn{2}{|l|}{ D Indoor Environmental Quality } & $0 \%$ & 0,0 \\
\hline & \multicolumn{2}{|l|}{ E Service Quality } & $0 \%$ & 0,0 \\
\hline & \multicolumn{2}{|l|}{ F Social and Economic aspects } & $6 \%$ & 4,1 \\
\hline \multirow{2}{*}{$\begin{array}{l}\text { Design Phase scores indicate Potential Performance as predicted by an assessment } \\
\text { of building features and plans for construction and operation that are developed } \\
\text { during the design process. }\end{array}$} & \multicolumn{2}{|c|}{ G Cultural and Perceptual Aspects } & $3 \%$ & 4,3 \\
\hline & \multicolumn{3}{|c|}{ Total welghted building score } & 2,0 \\
\hline
\end{tabular}

O conjunto Atibaia D apresentou um desempenho um pouco melhor em alguns aspectos. Mas é necessário fazer a mesma observação que foi feita para o Conjunto Marechal Tito: não foram considerados todos os indicadores e dessa maneira a avaliação poderia se diferente.

Como diversos indicadores relacionados às emissões, consumo de energia, materiais resíduos gerados e energia incorporada nos materiais foram desligados, os dois conjuntos não foram avaliados pela planilha relacionada às emissões. O resultado da planilha para os dois é nulo e igual e está apresentado a seguir para ilustrar o que poderia ser avaliado pelo método SBTool: 
Tabela 25 Tabela com a avaliação das emissões

Absolute Performance Results

These data are based on the Self-Assessment values

Total net consumption of primary embodied energy for structure and envelope, GJ/m2 Net annualized consumption of embodied energy for envelope and structure, $\mathrm{MJ} / \mathrm{m}^{*}{ }^{*} \mathrm{yr}$. Net annual consumption of delivered energy for building operations, $\mathrm{MJ} / \mathrm{m2}^{*}$ year Net annual consumption of primary non-renewable energy for building operations, $\mathrm{MJ} / \mathrm{m} 2^{*} \mathrm{yr}$. Net annual consumption of primary non-renewable energy per dwelling unit in project, $\mathrm{MJ} / \mathrm{m} 2^{*} \mathrm{yr}$. Net annual consumption of primary non-renewable energy per dwelling unit in residential element, $\mathrm{MJ} / \mathrm{m}^{*} \mathrm{yr}$.

Net annualized primary embodied energy and annual operating primary energy, $\mathrm{MJ} / \mathrm{m}^{*} \mathrm{yr}$.

Total on-site renewable energy used for operations, $\mathrm{MJ} / \mathrm{m}^{*} \mathrm{yr}$.

Net annual consumption of potable water for building operations, L / m2 * year

Annual use of grey water for building operations, L / m2 * year

Net annual GHG emissions from building operations, kg. CO2 equivalent per year

Total present value of 25-year life-cycle cost fot total project, 0 per m2.

Proportion of gross area of existing structure(s) re-used in the new project, percent

Proportion of gross area of project provided by re-use of existing structure(s), percent

\begin{tabular}{|c|c|l|}
\hline By area & \multicolumn{2}{|c|}{ By area \& occupancy } \\
\hline 0 & 0 & $\mathrm{GJ} / \mathrm{m}^{2 *} \mathrm{maph}$ \\
\hline 0 & 0 & $\mathrm{MJ} / \mathrm{m}^{2 *} \mathrm{maph}$ \\
\hline 0 & 0 & $\mathrm{MJ} / \mathrm{m}^{2 *} \mathrm{maph}$ \\
\hline 0 & 0 & $\mathrm{MJ} / \mathrm{m}^{2 *} \mathrm{maph}$ \\
\hline 0 & 0 & $\mathrm{MJ} / \mathrm{m}^{2 *} \mathrm{maph}$ \\
\hline 0 & 0 & $\mathrm{MJ} / \mathrm{m}^{2 *} \mathrm{maph}$ \\
\hline 0 & 0 & $\mathrm{MJ} / \mathrm{m}^{2 *} \mathrm{maph}$ \\
\hline 0 & $\# \mathrm{REF} !$ & $\mathrm{MJ} / \mathrm{m}^{2 *} \mathrm{maph}$ \\
\hline$\# \mathrm{DIV} / 0 !$ & $\# \mathrm{DIV} / 0 !$ & $\mathrm{m}^{3} / \mathrm{m}^{2 *} \mathrm{maph}$ \\
\hline 0 & $\# \mathrm{REF} !$ & $\mathrm{m}^{3} / \mathrm{m}^{2 *} \mathrm{maph}$ \\
\hline 0 & 0 & $\mathrm{~kg} / \mathrm{m}^{2 *} \mathrm{maph}$ \\
\hline \multicolumn{4}{|c}{} \\
\hline \multicolumn{4}{|c}{} \\
\hline \multicolumn{4}{|c}{$0 \%$} \\
\hline \multicolumn{3}{|c}{} \\
\hline
\end{tabular}

A tabela 25 mostra os resultados das emissões dos conjuntos caso fossem avaliados neste item.

Uma outra observação a respeito da avaliação do método que deve ser feita é que as fórmulas existentes por todo o método não foram estudadas. $A$ intenção da avaliação era verificar a aplicabilidade do método e de seus indicadores somente. Seria necessário um estudo exclusivo e profundo do método para detalhamento das fórmulas uma vez que elas não estão explícitas.

A respeito do resultado final da avaliação dos conjuntos e mesmo das práticas construtivas, pode-se afirmar que são necessárias mais informações a respeito dos projetos, não somente por parte da CDHU, mas também por parte dos fabricantes e fornecedores dos materiais em geral.

\subsection{AVALIAÇÃO PELO MÉTODO AQUA}

O método AQUA tem uma configuração bem diferente da dos outros métodos, por ser um método que estabelece um perfil ao invés de uma pontuação. A forma como o AQUA avalia um empreendimento também é diferente: o empreendimento pode atender ou não as diversas preocupações existentes numa subcategoria. Cada subcategoria possui um determinado 
número de preocupações (variam de 4 a 5 para a categoria 1) que devem ser atendidas para se atingir o nível Base, outras tantas para se atingir o nível Superior e ter todas atendidas, praticamente para atingir o nível Excelente.

O objetivo da utilização de parte deste método foi essencialmente entender como é feita a avaliação dentro da categoria, entender como o método funciona e que indicadores são abordados para a área urbana na qual o empreendimento será inserido.

Infelizmente, com os dados disponíveis não seria possível avaliar os conjuntos por todas as 14 categorias. Outra observação importante a ser feita é que somente os projetos foram utilizados para a análise, não seria possível, ainda utilizar o Sistema de Gestão do Empreendimento - SGE, único entre todos os métodos.

A seguir as três subcategorias da categoria "Relação do edifício com seu entorno" são apresentadas. As categorias são constituídas por tabelas em que a primeira coluna corresponde à preocupação principal da subcategoria, logo após vem a coluna dos indicadores e depois o critério de avaliação que na maioria das subcategorias da categoria 1 se referem às medidas tomadas no projeto relacionadas a cada preocupação. As duas colunas cinzas correspondem aos empreendimentos, o Marechal Tito e o Atibaia $D$ a cada preocupação é preenchido $A$ de Atende ou N/A de Não Atende. 
Tabela 26 Avaliação pela subcategoria 1.1 do AQUA

\section{Quadro de avaliação Sub Categoria 1.1}

\begin{tabular}{|c|c|c|c|c|}
\hline \multirow[b]{2}{*}{ Preocupação } & \multirow[b]{2}{*}{ Indicador } & \multirow{2}{*}{$\begin{array}{c}\text { Critério de avaliação } \\
\text { Título } \\
\end{array}$} & \multirow[b]{2}{*}{$\begin{array}{l}\text { Mar } \\
\text { Tito } \\
\end{array}$} & \multirow[b]{2}{*}{ Atibaia } \\
\hline & & & & \\
\hline $\begin{array}{l}\text { 1.1.1. Assegurar a } \\
\text { coerência entre a } \\
\text { implantação do } \\
\text { empreendimento no } \\
\text { terreno e a política da } \\
\text { comunidade em termos } \\
\text { de desenvolvimento } \\
\text { sustentável territorial }\end{array}$ & 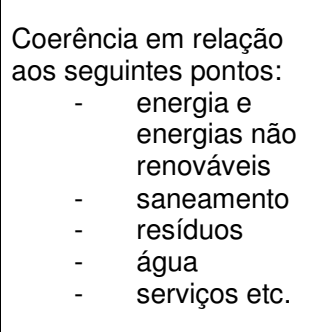 & $\begin{array}{l}\text { Medidas tomadas para a exploração } \\
\text { racional das redes e recursos } \\
\text { disponíveis localmente (energia, água, } \\
\text { saneamento), com o objetivo de } \\
\text { minimizar novos impactos na } \\
\text { comunidade local (resíduos, } \\
\text { manutenção das infra-estruturas etc.) } \\
\text { Atendimento das expectativas de } \\
\text { desenvolvimento sustentável da } \\
\text { comunidade }\end{array}$ & $\mathrm{N} / \mathrm{A}$ & N/A \\
\hline $\begin{array}{l}\text { 1.1.2. Gerenciar os meios } \\
\text { de transporte e favorecer } \\
\text { aqueles menos poluentes }\end{array}$ & $\begin{array}{l}\text { Conectividade urbana e } \\
\text { incentivo ao } \\
\text { deslocamento limpo (a } \\
\text { pé, por bicicleta etc.) }\end{array}$ & $\begin{array}{l}\text { Medidas tomadas para otimizar o uso } \\
\text { dos meios de transporte, sobretudo } \\
\text { considerando a emissão de poluentes }\end{array}$ & A & A \\
\hline $\begin{array}{l}\text { 1.1.3. Preservar o } \\
\text { ecossistema e a } \\
\text { biodiversidade }\end{array}$ & $\begin{array}{l}\text { Preservação / melhoria } \\
\text { da qualidade ecológica } \\
\text { do local do } \\
\text { empreendimento e da } \\
\text { biodiversidade } \\
\end{array}$ & Medidas justificadas e satisfatórias & $\mathrm{N} / \mathrm{A}$ & A \\
\hline $\begin{array}{l}\text { 1.1.4. Prevenir o risco de } \\
\text { inundação nas áreas } \\
\text { suscetíveis e limitar a } \\
\text { propagação de poluentes }\end{array}$ & $\begin{array}{l}\text { Ações para limitar o } \\
\text { escoamento das águas } \\
\text { pluviais }\end{array}$ & $\begin{array}{l}\text { Medidas tomadas para otimizar o } \\
\text { binômio retenção / infiltração de água } \\
\text { Recuperação das águas de escoamento } \\
\text { poluídas e tratamento de acordo com } \\
\text { sua natureza antes de liberá-las }\end{array}$ & $\mathrm{N} / \mathrm{A}$ & N/A \\
\hline
\end{tabular}

\section{SUBCATEGORIA}

1.1

\begin{tabular}{|c|c|c|}
\hline \multicolumn{2}{|c|}{1.1 .1} & \multicolumn{2}{|c|}{\begin{tabular}{|c|}
\hline 1.2 \\
\cline { 1 - 1 }
\end{tabular} Atende } & NA & NA \\
\hline
\end{tabular}

\begin{tabular}{|c|c|}
\hline \multicolumn{2}{|c|}{1.1 .3} \\
\hline Atende & NA \\
\hline
\end{tabular}

\begin{tabular}{|l|l|}
\hline \multicolumn{2}{|c|}{1.1 .4} \\
\hline Atende & NA \\
\hline
\end{tabular}

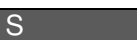

3 atendidas das 4 *

Fonte: Vanzolini, 2007

Na subcategoria 1.1 somente o Atibaia D atende duas preocupações: sobre o incentivo aos deslocamentos limpos e a preservação do ecossistema e biodiversidade e por este motivo seu desempenho é BASE. O Marechal Tito só conseguiu atender a preocupação relacionada ao transporte, o conjunto habitacional está localizado numa região com muitas linhas de ônibus e também fica próximo à estação de trem Itaim Paulista. O automóvel não é um meio de locomoção incentivado nos conjuntos habitacionais, principalmente pelo baixo poder aquisitivo da população. 
Tabela 27 Avaliação pela subcategoria 1.2 do AQUA

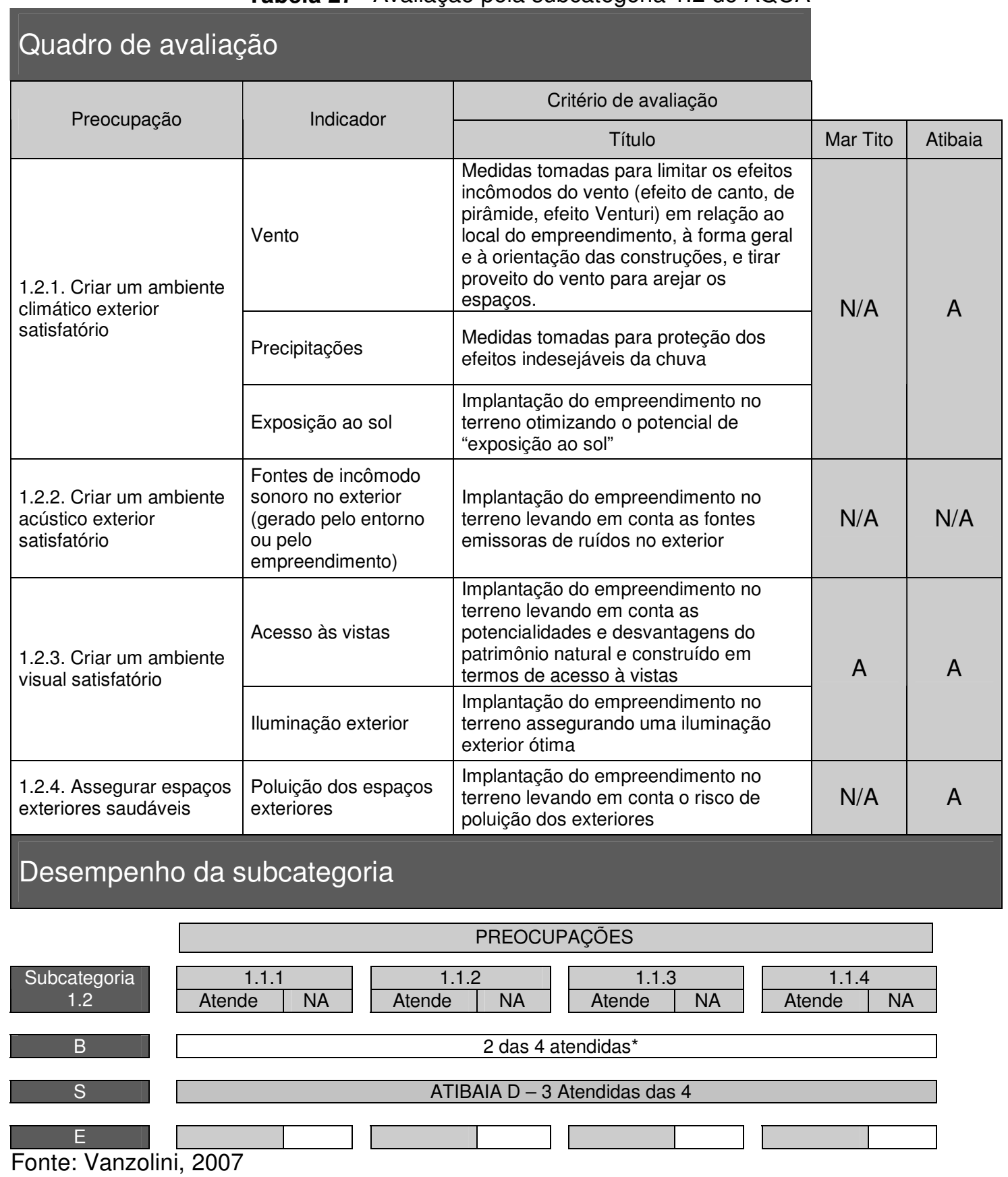

Na subcategoria 1.2, o conjunto Atibaia $D$ atende a três preocupações: ambiente climático e visual satisfatórios e espaços exteriores saudáveis. Com essa configuração, atinge o nível superior, deixando de atender somente o conforto acústico porque não feita nenhuma medição no terreno, apesar de se saber que o nível de ruído é baixo, pela localização, longe de fontes de ruído e num bairro mais afastado do centro urbano. O conjunto Marechal Tito conseguiu atender somente a uma das quatro preocupações da subcategoria. 
Tabela 28 Avaliação pela subcategoria 1.3

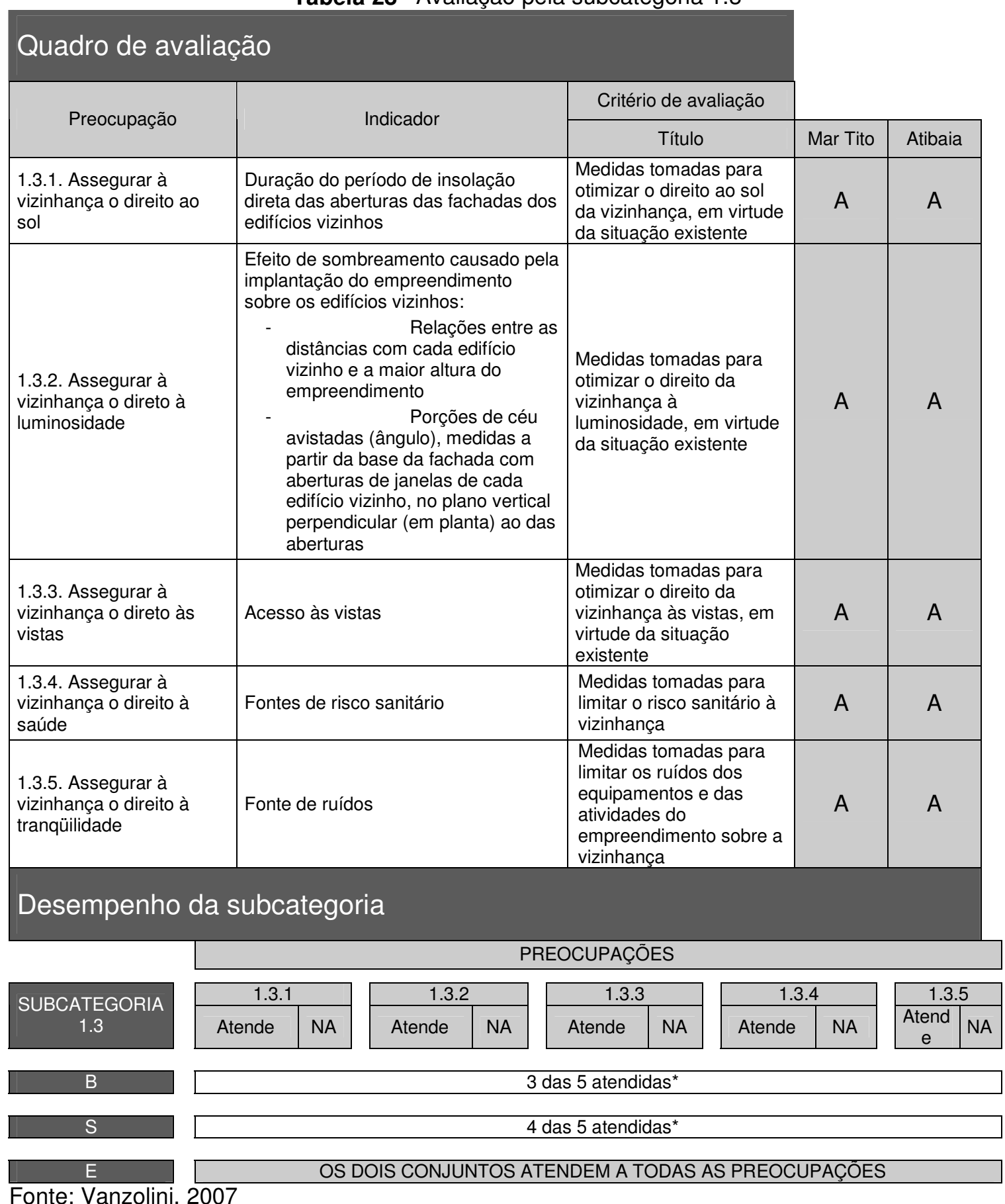

Os dois empreendimentos atendem a todas as preocupações e pela configuração dos conjuntos, não existe um grande impacto na vizinhança, mas é necessário também que os projetos tivessem apresentado uma preocupação com relação ao uso da água e da energia. O desempenho no referencial depende do perfil de cada categoria. A figura 30 demonstra como deve ser o perfil de um empreendimento para que ele consiga ser Base, Superior ou 
Excelente:

Tabela 29 Perfil geral dos conjuntos

\section{SUBCATEGORIAS}

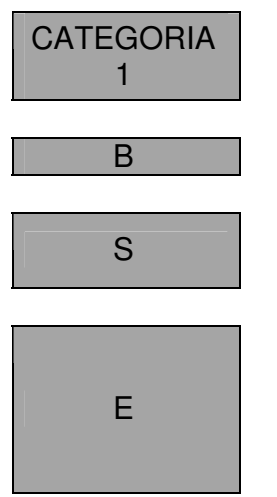

Fonte: Vanzolini, 2007
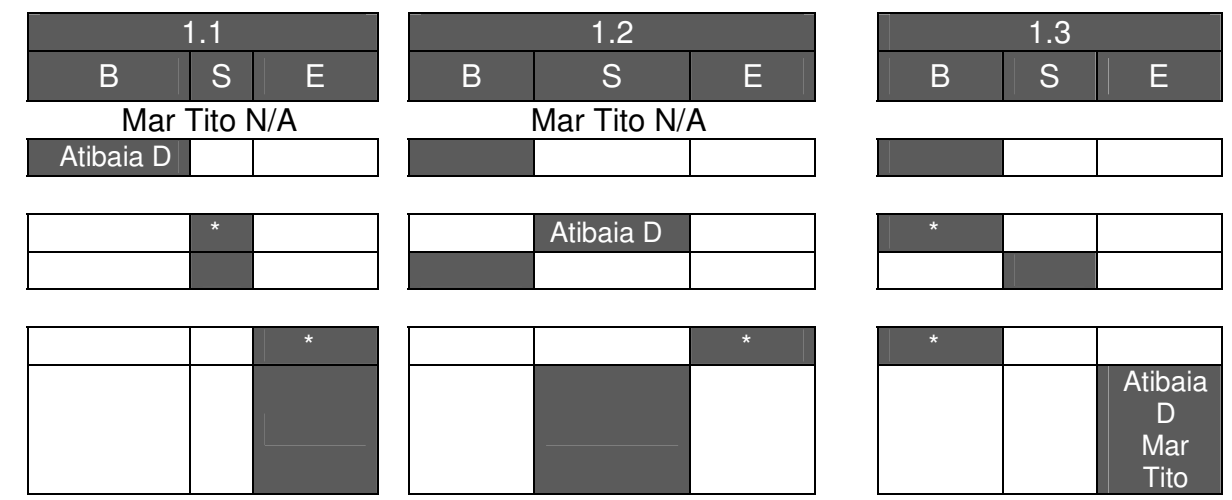

Atibaia D - BASE e Mar Tito não classifica.

Para que o Atibaia D fosse considerado como SUPERIOR, ele precisaria ter o seguinte perfil:

- 1.1 - Superior

- 1.2 - Base ou Superior

- 1.3 - Base ou Superior

No entanto, o perfil do empreendimento foi Base na 1.1, Superior na 1.2 e Excelente na 1.3. Apesar do AQUA não possuir uma estrutura de pontuação, ou ponderação ele consegue estabelecer as prioridades pelo modo como o perfil é organizado, pode-se concluir que a subcategoria mais importante na Categoria 1 é a 1.1. A partir desta categoria é que o empreendimento define qual será o tipo de desempenho que irá escolher.

\subsection{AVALIAÇÃO PELO LEED-ND}

Dos cinco métodos avaliados, O LEED-ND é o único que dá um peso maior às áreas urbanas. Desenvolvido a partir dos princípios do New Urbanism, Smarth Growth e Green Building, além de conter os indicadores comuns a todos os métodos como, por exemplo, uso eficiente da água e da energia, ele inclui outros para a avaliação do desenho urbano, que avaliam características 
como densidade do local e entorno, tanto em relação às unidades habitacionais por área, tanto em relação à densidade de ruas, à dependência em relação ao automóvel, e o quanto o desenho urbano é agradável ao pedestre.

Diferentemente das outras versões do sistema, o LEED-ND possui outros pré-requisitos, relacionados ao ambiente urbano. O método foi aplicado aos dois conjuntos, e os resultados são expostos nas tabelas com os indicadores referentes a cada categoria.

A tabela na qual a avaliação é apresentada foi obtida no website do USGBC (www.usgbc.org) e é uma adaptação do lista de verificação fornecido. As três colunas à direita dos textos dos créditos mostram a pontuação dos conjuntos, quantos pontos são Atendidos (A), quantos são Incertos (I) e quantos Não são Atendidos (N/A).

Quando o crédito possui mais que um indicador, o indicador está especificado na linha abaixo em uma fonte menor, e o resultado do conjunto está na área verde ou na coluna Atendido ( $A$ ) ou na Não Atendido (N/A).

O sistema é dividido entre pré-requisitos e créditos, o atendimento aos pré-requisitos é obrigatório, sem eles o empreendimento não pode ser certificado, já os créditos são opcionais, o empreendedor escolhe quantos poderá atender. O primeiro pré-requisito - Localização Apropriada, na verdade pede que se comprove que o empreendimento está localizado numa área urbana já desenvolvida. Esta é a opção que os conjuntos atendem, mas existem outras. As opções que são detalhadas neste estudo são somente as atendidas pelos conjuntos. A avaliação da categoria 1- localização inteligente e conectividade são apresentadas na tabela 25. 
Tabela 30 avaliação do método pela categoria

\begin{tabular}{|c|c|c|c|c|c|c|c|c|}
\hline & & & Ma & Tit & & Ati & aia & \\
\hline & & & A & 1 & $\mathrm{~N} / \mathrm{A}$ & A & 1 & $\mathrm{~N} / \mathrm{A}$ \\
\hline Localiza & ação inteligente e conectividade & os Possíveis & 19 & 0 & 11 & 17 & 0 & 13 \\
\hline Prereq 1 & $\begin{array}{l}\text { Localização apropriada } \\
\text { escolher área que seja servida de serviços e infra-estrutura } \\
\text { urbana }\end{array}$ & Obrigatorio & s & & & s & & \\
\hline Prereq 2 & Proximidade à infra-estrutura de água e esgoto & Obrigatorio & s & & & s & & \\
\hline Prereq 3 & $\begin{array}{l}\text { Comunidades ecológicas e espécies ameaçadas de } \\
\text { extinção }\end{array}$ & Obrigatorio & $\mathrm{s}$ & & & $\mathrm{s}$ & & \\
\hline Prereq 4 & Conservação dos corpos de água e áreas alagáveis & Obrigatorio & $\mathrm{s}$ & & & $\mathrm{s}$ & & \\
\hline Prereq 5 & Conservação de solo fértil para a agricultura & Obrigatorio & s & & & $\mathrm{s}$ & & \\
\hline Prereq 6 & Prevenção contra inundação & Obrigatorio & $\underline{s}$ & & & $s$ & & \\
\hline Credit 1 & Recuperação e desenvolvimento de áreas degradadas & 2 & & & 2 & & & 2 \\
\hline Credit 2 & Prioridade a áreas urbanas degradadas & 1 & & & 1 & & & 1 \\
\hline Credit 3 & Escolha de áreas já urbanizadas & 10 & 10 & & & 7 & & \\
\hline & $\begin{array}{l}\text { Terreno já desenvolvido + de } 10 \text { a +de } 40 \text { milhas } \\
\text { lineares/milhas2 }\end{array}$ & & 71 & & & 18,75 & & 3 \\
\hline Credit 4 & Redução da dependência do automóvel & 8 & 7 & & & 4 & & \\
\hline & $\begin{array}{l}\text { No de viagens do transporte público existente a até } 400 \mathrm{~m} \text { do } \\
\text { empreendimento para ônibus e } 800 \text { para trem ou metro }\end{array}$ & & 1237 viagens & & 1 & 110 viagens & & 4 \\
\hline Credit 5 & Infra-estrutura para bicicleta & 1 & & & 1 & & & 1 \\
\hline Credit 6 & Proximidade entre habitação e centros de emprego & 3 & & & 3 & 2 & & 1 \\
\hline Credit 7 & proximidade a escolas & 1 & 1 & & & 1 & & \\
\hline Credit 8 & Proteção às altas declividades & 1 & 1 & & & 1 & & \\
\hline Credit 9 & Preservação de áreas verdes e ribeirinhas & 1 & & & 1 & 1 & & \\
\hline Credit 10 & Recuperação de habitats ou áreas alagáveis & 1 & & & 1 & 1 & & \\
\hline Credit 11 & Gerenciamento para conservação de habitats e áreas & 1 & & & 1 & & & 1 \\
\hline
\end{tabular}

Nesta categoria o método avalia a escolha da área para a implantação do empreendimento, dessa maneira, a maior parte dos indicadores é comum aos outros métodos, como proximidade à infra-estrutura urbana, preservação das características naturais do terreno, prevenção de inundação etc. No entanto, dois créditos merecem uma explicação mais detalhada como é o caso dos créditos 3 e 4 .

No crédito 3-Escolha de áreas já urbanizadas, o sistema usa um indicador de densidade de ruas do entorno ao empreendimento: no raio de uma milha $(1,6 \mathrm{~km})$, as extensões de todas as ruas são somadas em milhas e em seguida divide-se o resultado pela área em milhas quadradas. Tanto no Marechal Tito quanto no Atibaia D, utilizou-se o software Google Earth para medir a extensão destas ruas, mas num software de sistemas de informações por geoprocessamento, esta informação é mais rápida e simples de ser obtida.

Para este crédito-3, a pontuação é maior, conforme for mais ruas/área houver, no caso, o Marechal Tito possui uma densidade de ruas quatro vezes maior que o Atibaia $D$. 
Outro crédito que merece uma explicação é o crédito4-Redução da dependência do automóvel. Neste crédito o sistema usa um indicador de viagens de transporte público por dia. Todas as linhas de ônibus que passam a até $400 \mathrm{~m}$ do empreendimento e quantas vezes elas passam. Tanto as viagens de ida quanto as viagens de volta, num dia de 24 horas, são contabilizadas. 0 Marechal Tito possui quase 12 vezes o número de viagens que o Atibaia $D$. A próxima categoria avalia o desenho urbano dos conjuntos. 
Tabela 31 avaliação pela categoria 2 - Projeto e padrão do bairro

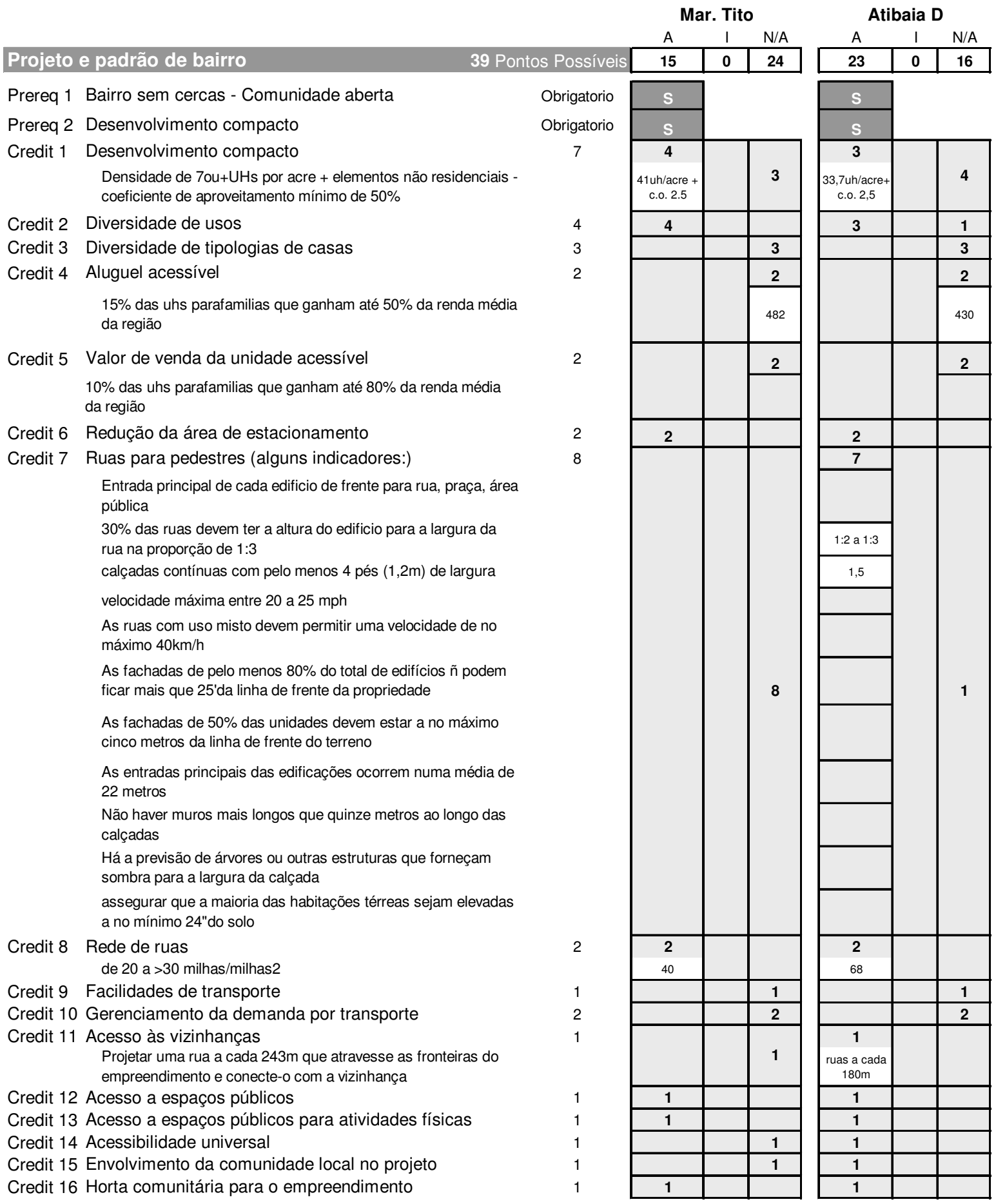

A categoria "desenho e padrão do bairro" contém os principais indicadores para avaliação do desenho urbano do empreendimento. O principal pré-requisito é que o empreendimento não seja fechado, não pode haver qualquer controle de acesso como portaria, cerca, ou portões que bloqueiem tanto o acesso de carros ou pedestres às ruas do empreendimento. Dessa 
maneira qualquer condomínio fechado não pode ser avaliado pelo método.

Por enquanto os conjuntos habitacionais da CDHU são como loteamentos que se inserem no tecido urbano e no qual não há delimitação com cercas, portões ou grades que o separem do resto do seu entorno e por este motivo conseguem atender o pré-requisito sem problemas.

Outro pré-requisito é o desenvolvimento compacto, de maneira a incentivar o preenchimento de espaços vazios no tecido urbano e desestimular a dispersão urbana, é necessário que o empreendimento possua uma densidade de no mínimo sete unidades habitacionais por acre e que se existirem elementos não-residenciais que estes possuam uma densidade de 0,50 FAR (Floor Area Ratio), que é a área construída total dividida pela área que pode ser ocupada dentro do terreno, que é equivalente ao coeficiente de aproveitamento do terreno.

A partir do atendimento ao pré-requisito um, o crédito um pontua a partir de uma combinação dos dois indicadores: quanto maior o número de unidades por acre houver e quanto maior o FAR dos elementos não residenciais, mais pontos são adquiridos no crédito.

O Marechal Tito possui 41 unidades habitacionais por acre enquanto o Atibaia $\mathrm{D}$ apresenta aproximadamente 34 . Apesar de não existir ainda o projeto para os equipamentos urbanos, a legislação para as Zonas Especiais de Interesse Social - ZEIS, determina que o coeficiente de ocupação seja 2,5 para as construções em conjuntos habitacionais. De acordo com a faixa de pontuação, o Marechal Tito fica com sete pontos e o Atibaia D com três.

O crédito 2-Diversidade de usos pede que o conjunto esteja a até 400metros de vários serviços, quanto maior o número de serviços e mais unidades habitacionais do empreendimento estiverem próximas a estes, maior a pontuação. O Marechal Tito tem um desempenho melhor que o Atibaia D.

No crédito sobre diversidade de tipologias, os dois conjuntos não conseguiram pontuar, pois a tipologia não varia, o Atibaia $D$ apesar de possuir duas tipologias apresenta um número pequeno de casas térreas. Para conseguir alguma pontuação é necessário que no mínimo, metade das unidades apresentem uma tipologia e a outra metade apresente outra.

Para que cidadãos de diversos níveis sociais possam adquirir uma 
unidade habitacional, o crédito-4 e o crédito- 5 estipulam que algumas das unidades devem ser destinadas aos diferentes níveis de renda que variam para mais ou para menos dependendo da renda média da população.

O crédito7-Ruas para pedestres é o mais complexo de todos os créditos presentes no método. A intenção do crédito é promover um ambiente que atraia e seja agradável para os pedestres, para que as pessoas deixem de usar o automóvel e aproveitem o bairro a pé. Só é possível pontuar no crédito a partir de quatro pontos. Cinco indicadores iniciais são apresentados, e todos precisam ser atendidos para que se consigam os quatro pontos.

- Entrada principal voltada para o espaço público

- $30 \%$ das ruas devem possuir uma configuração de 1:3, isto é a rua pode ter uma largura máxima igual a três vezes a altura do edifício. Ou seja, numa rua onde as edificações possuam $6 \mathrm{~m}$ de altura, as ruas deverão ter no máximo 18m de largura.

- Calçadas contínuas ao longo dos dois lados da rua e com uma largura de pelo menos $1,2 \mathrm{~m}$

- Todas as ruas ao longo dos blocos residenciais precisam devem permitir uma velocidade máxima de $32 \mathrm{~km} / \mathrm{h}$

- As ruas com uso misto devem permitir uma velocidade de no máximo $40 \mathrm{~km} / \mathrm{h}$

Se todos estes requisitos forem atendidos o empreendimento pode conseguir um ponto a cada dois requisitos atendidos da próxima lista:

- As fachadas de $80 \%$ das unidades habitacionais devem estar a no máximo sete metros da linha da frente do terreno

- As fachadas de $50 \%$ das unidades devem estar a no máximo cinco metros da linha de frente do terreno

- As entradas principais das edificações ocorrem numa média de 22 metros

- Não deve haver muros mais longos que quinze metros ao longo das calçadas

- Pelo menos 50\% das unidades habitacionais devem ser elevadas a no mínimo 61 centímetros

- O projeto prevê árvores entre o passeio e as ruas 
- Há a previsão de árvores ou outras estruturas que forneçam sombra para a largura da calçada

O Marechal Tito não consegue atender o segundo item dos cinco primeiros que devem ser atendidos para que o empreendimento consiga os quatro pontos, porque seu gabarito, em projeto e como quando foi entregue, apresenta uma proporção que varia de 1:4 até 1:6, dependendo da largura da rua. O Atibaia $\mathrm{D}$ consegue atingir sete pontos.

O crédito 8 - Densidade de ruas analisa a densidade de ruas dentro do empreendimento. Usando o mesmo indicador já apresentado anteriormente, ele mede a metragem linear de ruas pela área do empreendimento. $O$ Atibaia $D$ possui uma densidade maior com 68, enquanto o Marechal Tito tem 40.

O crédito 9- Facilidades de transporte pede que exista um projeto de comunicação visual que forneça informações sobre direções, pontos de ônibus. Pede também que o projeto possua bancos e abrigos nos pontos de transporte público, o Atibaia $D$ não atende ao crédito, o Marechal Tito possui um ponto de ônibus, mas que não possui todos os requisitos exigidos. Nenhum dos dois consegue atender o crédito

O crédito 10-Gerenciamento da demanda por transportes não é atendido, pois não existe um planejamento para se reduzir a tarifa do transporte público da região por um ano.

$\mathrm{O}$ crédito 11-Acesso às vizinhanças demanda que seja projetada uma conexão, ou seja, uma rua, uma alameda que atravesse o empreendimento e que se comunique com toda a malhar urbana do entorno a cada 243 metros. $O$ Atibaia $D$ atende 0 crédito, pois essa conexão é feita a cada 180 metros. $O$ Marechal Tito possui uma configuração mais isolada.

Os créditos restantes da categoria são semelhantes aos demais métodos que tratam da avaliação do entorno e as características do empreendimento, como acesso a espaços públicos, atividades físicas, envolvimento da comunidade local. No entanto vale destacar dois créditos, um deles o crédito 14-Acessibilidade Universal, é novidade no sistema LEED de avaliação, somente o LEED-ND possui o crédito relacionado à acessibilidade e somente o Atibaia $D$ atende. $O$ outro é o crédito 16 sobre horta comunitária que pode ser substituída por uma feira que ocorra toda semana e que possua 
produtores locais. Os dois conjuntos atendem este crédito.

A próxima categoria abriga os créditos que avaliam as características de um Green Building comum. Estes são bem semelhantes aos das outras versões do método, que consideram, os impactos da construção do empreendimento, uso eficiente da água e da energia, redução da ilha de calor, entre outros. A tabela 25 apresenta a avaliação dos conjuntos

Tabela 32 Avaliação pela categoria construção e tecnologias sustentáveis

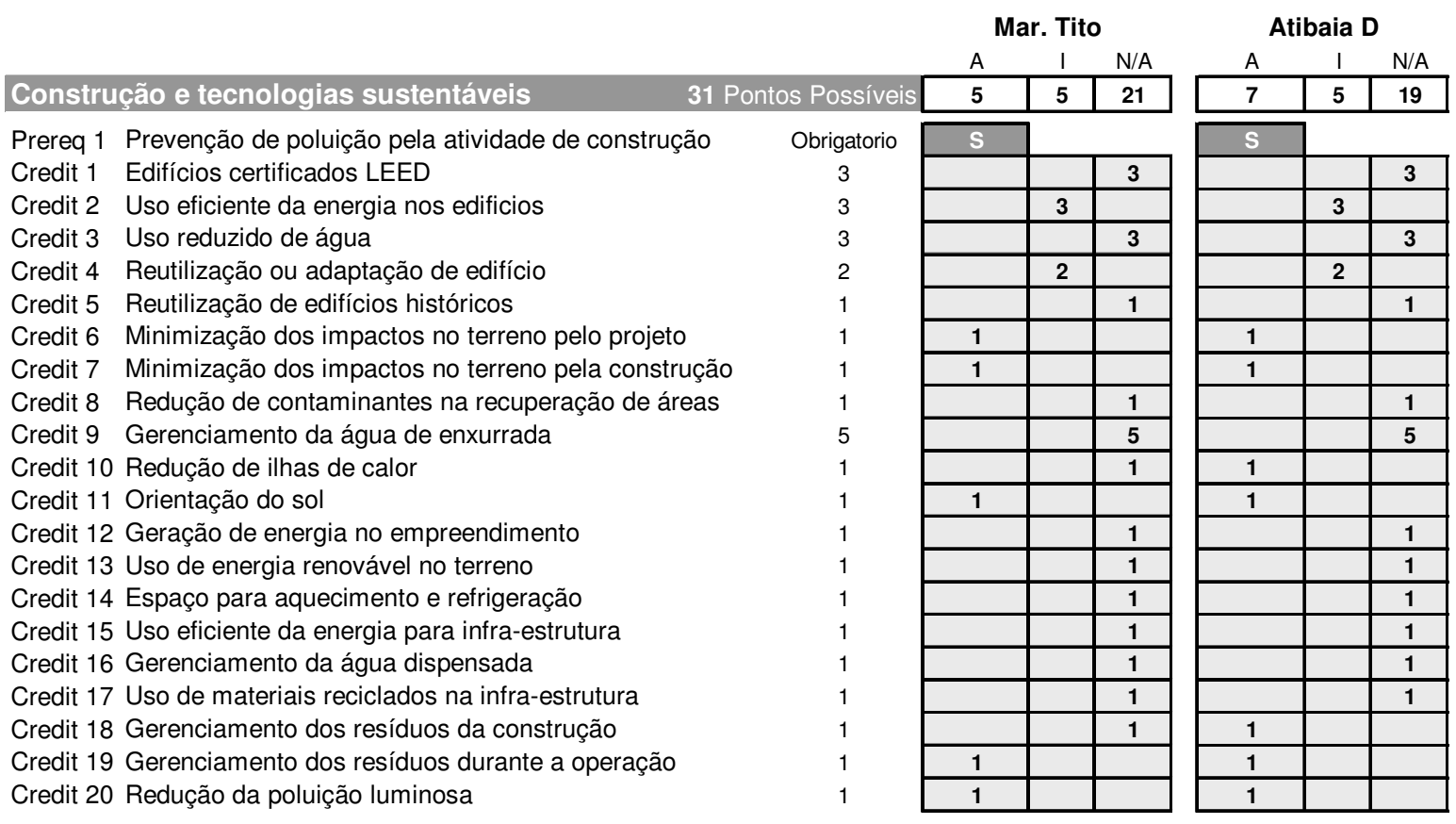

Esta é a categoria que os conjuntos pontuaram menos, quase nenhum crédito foi atendido, com exceção dos créditos sobre limitação dos impactos ao terreno pela construção ou pelo projeto, nos quais é exigido que o empreendimento seja implantado em áreas urbanas já consolidadas com infraestrutura pronta.

O Atibaia $\mathrm{D}$ atende o crédito correspondente à redução de ilha de calor, pois seu projeto prevê piso permeável tanto para as calçadas como para as ruas. Os dois conjuntos atendem o crédito de orientação solar, que determina a implantação de $75 \%$ das unidades do empreendimento orientadas a $15 \%$ do eixo leste-oeste.

Os conjuntos também atendem os créditos correspondentes ao gerenciamento de resíduos durante a operação, pois os dois apresentam programa de coleta seletiva de resíduos recicláveis e Redução da poluição 
luminosa, em que é avaliado se o empreendimento ofusca a visão do céu noturno fazendo uso de iluminação excessiva. Com relação a isto, os conjuntos são simples, não existe nenhuma iluminação especial além da iluminação das ruas.

Foram deixados alguns créditos como incertos: tanto o uso eficiente da água como o uso eficiente da energia. O sistema pede que sejam instalados equipamentos economizadores e eficientes. No entanto o consumo das famílias de baixa renda é muito baixo se comparado às famílias dos países desenvolvidos, mesmo com equipamentos comuns, por isso os dois são créditos que foram considerados como incertos.

A última categoria a ser apresentada é Inovação e processo de projeto. Esta categoria é uma oportunidade que o sistema oferece a quem ou teve um desempenho excepcional em qualquer dos créditos ou apresentou alguma solução inovadora que não está contemplada no sistema. A avaliação dos conjuntos é apresentada na tabela 11 juntamente com o resultado final da avaliação de ambos:

Tabela 33 Avaliação dos conjuntos pela categoria inovação e processo de projeto

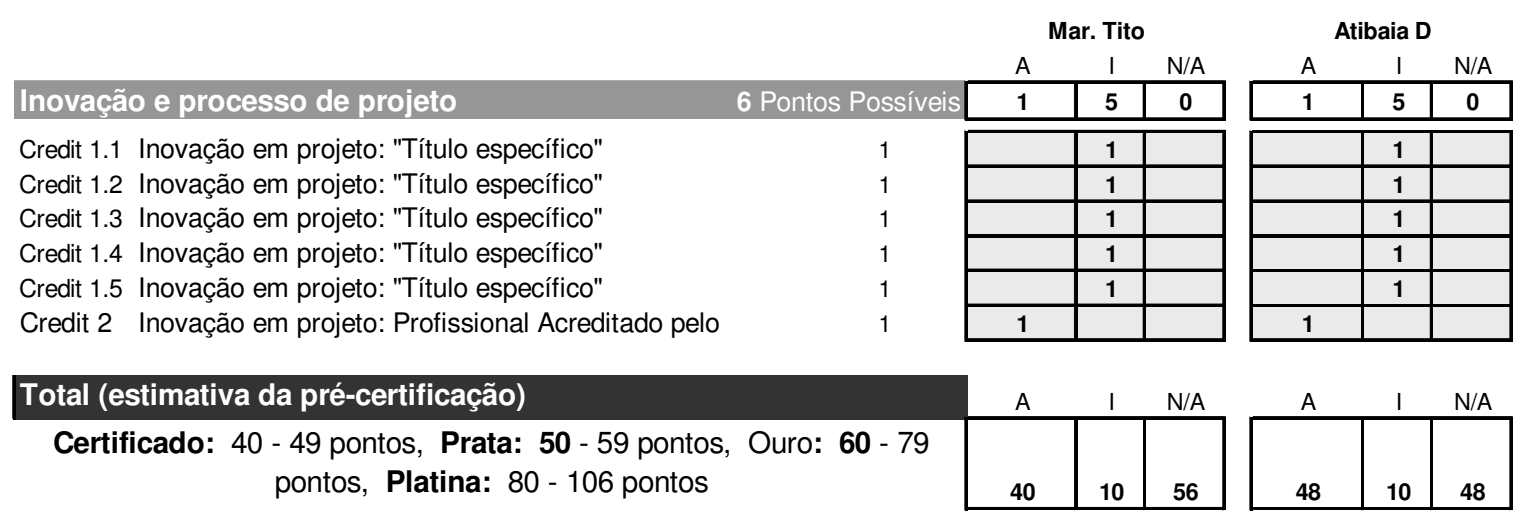

Todos os pontos dos créditos sobre inovação e processo de projeto foram deixados como incertos, pois documento que foi utilizado para a avaliação dos conjuntos é somente uma lista dos créditos com as explicações essenciais. O documento que faz todo o detalhamento dos procedimentos $\mathrm{e}$ como demonstrar o atendimento aos créditos é o Reference Guide, um guia explicativo do método que indica quais são as ações dentro dos créditos com desempenho excepcional que poderiam pontuar nos créditos de Inovação. Como o LEED-ND ainda está na fase piloto - em teste, os indicadores foram 
pesquisados independentemente do manual do método que ainda não foi lançado.

Os conjuntos foram bem avaliados pelo fato de serem densos (para os parâmetros dos Estados Unidos), localizarem-se em áreas já urbanizadas, e não privilegiarem o uso do automóvel, não por um principio de sustentabilidade, mas por falta de recursos da população mesmo. A diferença de pontuação entre o Marechal Tito e o Atibaia $D$ se baseia principalmente no desenho do Atibaia $D$ com hierarquia de ruas e sua forma em pequenas vilas, ao paisagismo e às áreas verdes com alto índice de permeabilidade, mas o Marechal Tito pontuou mais alto em relação à densidade e proximidade de serviços.

De acordo com esta avaliação inicial, os dois conjuntos poderiam ser certificados pelo método LEED-ND. O Marechal Tito ficou com 40 pontos, em cima da pontuação mínima para a certificação VERDE e o Atibaia D obteve 48 pontos a apenas dois da certificação PRATA. 


\section{DISCUSSÃO SOBRE OS RESULTADOS DAS AVALIAÇÕES PELOS MÉTODOS DE SUSTENTABILIDADE E CONSIDERAÇÕES FINAIS}

Este trabalho se propôs a fazer uma análise dos métodos de avaliação de sustentabilidade do ambiente construído, a partir de projetos dos conjuntos habitacionais, algumas entrevistas e visitas ao local.

O resultado exposto no capítulo anterior configurou-se um estudo que pode ser discutido. Foi realizado como que uma primeira análise a fim de verificar como os projetos se comportariam no caso de uma avaliação. Os resultados de uma avaliação real podem ser diferentes e 0 fato de apresentarem um bom desempenho em alguns métodos não representa necessariamente um bom desempenho sustentável, visto que a realidade brasileira possui prioridades para a sustentabilidade diversas.

Uma outra limitação do trabalho foi o enfoque dado às áreas urbanas, privilegiou-se a pesquisa a indicadores relacionados à implantação do empreendimento, à sua inserção urbana, relacionamento e impactos no entorno, etc.

Após a avaliação dos conjuntos por todos os métodos selecionados, é possível constatar que todos usam mais ou menos um conjunto mínimo com os mesmos indicadores para avaliar o desempenho de empreendimentos. E que de uma maneira geral existem indicadores que podem ser aplicados a diferentes realidades, pois eles são essenciais para demonstrar um bom desempenho ambiental ou sustentável. O que diferencia um método de outro, é a estrutura sobre a qual se organiza e a prioridade que estabelece para avaliar determinados aspectos.

Como exemplo, é possível comparar o LEED-ND e o SBTool, que consideram para sua avaliação os mesmos requisitos ambientais. Contudo, o LEED-ND dá uma ênfase muito maior aos aspectos urbanos enquanto o SBTool dá maior destaque à questão das emissões e da energia.

De uma maneira geral, o desempenho dos conjuntos foi de ruim a razoável em quatro dos cinco métodos considerados. O único que apresentou um bom desempenho dos conjuntos foi o LEED-ND, por ser diferente dos 
outros e dar um enfoque maior na avaliação ao contexto urbano como infraestrutura e serviços, e ao desenho urbano. Apesar do AQUA não ter sido utilizado completamente, a categoria um serviu para confirmar a avaliação dos outros métodos.

Foram estudados cerca de 350 indicadores, ao todo contando todos os métodos. Para se desenvolver as conclusões sobre aplicabilidade destes indicadores foi elaborada uma matriz em que os indicadores foram sintetizados e agrupados de acordo com categorias maiores. Os indicadores em fonte normal foram aplicados aos conjuntos, os indicadores em itálico não conseguiram avaliar os dois conjuntos seja por falta de dados dos projetos ou dados nacionais, etc.

Considerou-se o desempenho dos conjuntos no geral, não foram separados os desempenhos individuais de cada um, se um dos dois atendeu o requisito ele foi considerado como atendido. Este critério foi adotado por que o desempenho dos dois conjuntos em todos os métodos foi muito parecido.

Figura 24 Matriz 1 - Resumo dos indicadores estudados nos métodos

\begin{tabular}{|c|c|c|c|c|c|c|c|}
\hline \multirow{2}{*}{\multicolumn{2}{|c|}{ Indicadores agrupados por categorias }} & \multicolumn{5}{|c|}{$\begin{array}{l}\text { Métodos de Avaliação } \\
\text { de sustentabilidade }\end{array}$} & \multirow{2}{*}{ 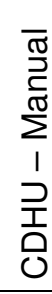 } \\
\hline & & $\begin{array}{l}\text { Q } \\
\text { 仓’ } \\
\text { 岂 } \\
\end{array}$ & $\begin{array}{l}\text { 这 } \\
\infty \\
\infty\end{array}$ & $\begin{array}{l}\overline{8} \\
\frac{8}{0} \\
\text { c }\end{array}$ & 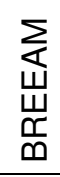 & 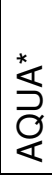 & \\
\hline 1 & Localização e relação do empreendimento com & eu e & ntor & & & & \\
\hline 1.1 & $\begin{array}{l}\text { Proximidade de serviços comerciais e culturais, } \\
\text { atividades de lazer e transporte público e } \\
\text { empregos }\end{array}$ & $\bullet$ & $\bullet$ & $\bullet$ & $\bullet$ & $\bullet$ & $\bullet$ \\
\hline 1.2 & $\begin{array}{l}\text { Recuperação/ re-desenvolvimento de áreas } \\
\text { contaminadas }\end{array}$ & $\bullet$ & $\bullet$ & $\bullet$ & & & \\
\hline 1.3 & $\begin{array}{l}\text { Densidade de ruas do entorno e do } \\
\text { empreendimento }\end{array}$ & • & & & & & \\
\hline 1.4 & Vulnerabilidade do terreno à riscos ambientais & $\bullet$ & $\bullet$ & $\bullet$ & $\bullet$ & $\bullet$ & $\bullet$ \\
\hline 1.5 & Acesso à infra-estrutura urbana & $\bullet$ & $\bullet$ & $\bullet$ & $\bullet$ & $\bullet$ & $\bullet$ \\
\hline 1.6 & $\begin{array}{l}\text { Proteção às características ecológicas do } \\
\text { terreno e entorno }\end{array}$ & • & $\bullet$ & & $\bullet$ & & $\bullet$ \\
\hline 1.7 & Presença de áreas verdes e permeáveis & $\bullet$ & $\bullet$ & $\bullet$ & $\bullet$ & $\bullet$ & $\bullet$ \\
\hline 1.8 & Incentivo ao uso de transporte limpo & $\bullet$ & $\bullet$ & $\bullet$ & $\bullet$ & $\bullet$ & \\
\hline 1.9 & Impacto do empreendimento na vizinhança & $\bullet$ & $\bullet$ & $\bullet$ & $\bullet$ & $\bullet$ & $\bullet$ \\
\hline
\end{tabular}




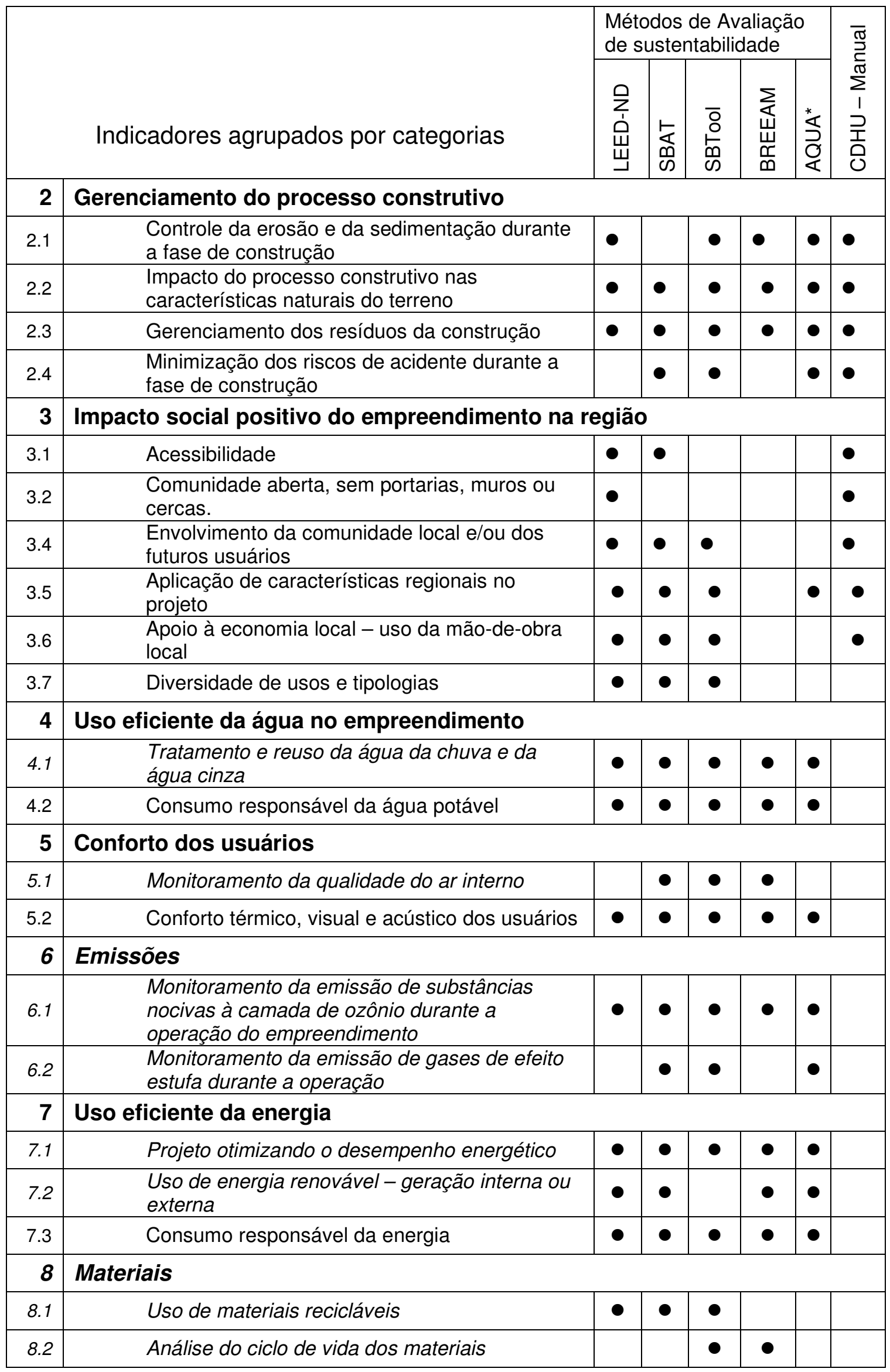




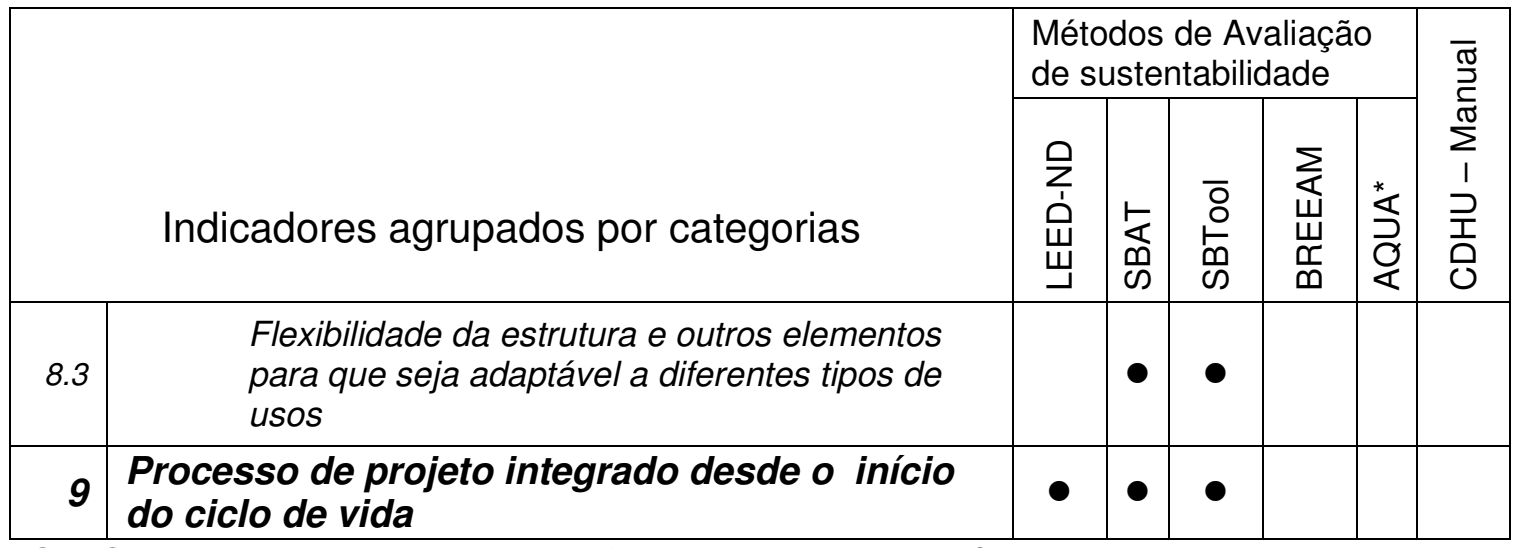

${ }^{*} O$ AQUA possui uma estrutura diferente dos outros métodos, devido a isto, os itens acrescentados à tabela correspondem às preocupações globais do método no que se refere somente à categoria 1 - $\mathrm{O}$ edifício e seu entorno.

A maioria dos requisitos de sustentabilidade atendidos pelos conjuntos que se refere à implantação do conjunto no tecido urbano, no geral, apresentou um bom desempenho em requisitos como localização, integração à área urbana local, baixo impacto à vizinhança e colaboração dos moradores. Os conjuntos são densos - para os padrões estipulados pelos métodos, bem localizados e bem servidos de serviços urbanos, foram implantados em vazios urbanos, se encaixam na paisagem urbana existentes. O consumo de água e energia é baixo, e os conjuntos apresentaram um resultado favorável em indicadores que mediram a quantidade de consumo destes recursos.

No entanto, nenhum dos dois conjuntos conseguiu atender indicadores como: uso de outro tipo de água que não a potável, não há projeto de captação da água da chuva ou de reuso da água utilizada no empreendimento e também não apresentam nenhuma iniciativa quanto ao uso de materiais recicláveis ou reciclados, muito menos iniciativas quanto ao uso de energia renovável tanto dentro do empreendimento como fora dele, além de outros requisitos relacionados ao uso e operação.

Os sistemas dão um peso maior para estas questões de acordo com a realidade para qual foram desenvolvidos. No geral, quase todos fazem menção a transportes não poluentes como deslocamento a pé, uso de bicicletas, patins etc. A possibilidade do uso de bicicletas em cidades menores como Atibaia é perfeitamente possível, apesar de não existir uma infra-estrutura específica com ciclovias, bicicletários, chuveiros etc. Em cidades como São Paulo, o uso já é mais complicado, visto que o trânsito da cidade é caótico e não existe uma 
estrutura de ciclovias, por exemplo.

Outro indicador sobre transportes que merece atenção é o que se refere à presença de pontos de ônibus a menos de $400 \mathrm{~m}$ do empreendimento. Os dois conjuntos atendem este indicador, o Marechal Tito possui até uma rede de pontos muito maior que o Atibaia $\mathrm{D}$, no entanto a localização dos conjuntos nas periferias das cidades está muito longe dos centros de emprego que consigam absorver toda a mão de obra.

No caso do bairro onde está inserido o Marechal Tito, o Itaim Paulista é um bairro dormitório a quantidade de serviços existentes na região não consegue absorver a quantidade de pessoas que habitam o distrito.

A CDHU considera a presença de oportunidade de empregos, no entanto é um número muito limitado de vagas ligadas ao comércio que não consegue absorver toda a mão de obra.

Uma observação importante é que os indicadores precisam estar afinados com o objeto de avaliação. Funciona como uma lente: é possível enxergar o todo mas sem a lente apropriada a clareza e o entendimento dos detalhes é comprometido, ou seja é possível enxergar mas não existe precisão. Com uma lente apropriada, é possível visualizar toda a complexidade de detalhes para um perfeito entendimento do objeto que está sendo observado.

\subsection{A APLICABILIDADE DOS MÉTODOS}

Esta pesquisa teve como objetivo estudar alguns sistemas de avaliação de sustentabilidade do ambiente construído desenvolvidos internacionalmente para analisar seus indicadores, estrutura e a sua aplicabilidade na avaliação da implantação de conjuntos habitacionais no contexto da realidade brasileira.

A partir da revisão bibliográfica os cinco métodos selecionados avaliaram dois conjuntos habitacionais, um desenvolvido sob uma perspectiva mais tradicional e outro sob uma perspectiva mais inovadora e algumas novas preocupações com o desenho urbano que não existiam anteriormente. Para resumir as conclusões a respeito dos métodos foi elaborado na tabela 34 : 
Tabela 34 Quadro resultado final dos métodos

\begin{tabular}{|c|c|c|c|c|c|}
\hline & & & & & \\
\hline ، & ECOHOMES & SBAT & SBTOOL & $\begin{array}{l}\text { AQUA - } \\
\text { categoria } 1\end{array}$ & LEED-ND \\
\hline Entendimento & Fácil & Fácil & $\begin{array}{l}\text { Difícil - } \\
\text { estrutura } \\
\text { complexa }\end{array}$ & $\begin{array}{l}\text { Mediano - } \\
\text { muito } \\
\text { diferente dos } \\
\text { outros } \\
\text { métodos }\end{array}$ & Fácil \\
\hline $\begin{array}{l}\text { Método - } \\
\text { Aplicação }\end{array}$ & Dificil & $\begin{array}{c}\text { Mediana -é } \\
\text { difícil traduzir o } \\
\text { dados numa } \\
\text { porcentagem } \\
\text { de } 0 \text { a } 100 \\
\end{array}$ & Dificil & Mediana & $\begin{array}{l}\text { Mediano - } \\
\text { cada drédito } \\
\text { demorou em } \\
\text { média } 1 \text { dia de } \\
\text { estudo }\end{array}$ \\
\hline $\begin{array}{l}\text { Realidade } \\
\text { brasileira }\end{array}$ & $\begin{array}{l}\text { Não se } \\
\text { aplica }\end{array}$ & Aplicável & $\begin{array}{c}\text { Alguns } \\
\text { indicadores } \\
\text { conseguem } \\
\text { ser aplicados }\end{array}$ & Aplicável & $\begin{array}{c}\text { Aplicável } \\
\text { com algumas } \\
\text { restrições }\end{array}$ \\
\hline $\begin{array}{l}\text { Conjuntos } \\
\text { habitacion } \\
\text { ais }\end{array}$ & $\begin{array}{c}\text { Aplicável aos } \\
\text { britânicos }\end{array}$ & Aplicável & $\begin{array}{c}\text { Alguns } \\
\text { indicadores } \\
\text { conseguem } \\
\text { ser aplicados }\end{array}$ & Aplicável & $\begin{array}{c}\text { Aplicável } \\
\text { com algumas } \\
\text { restrições }\end{array}$ \\
\hline $\begin{array}{l}\text { Áreas } \\
\text { urbanas }\end{array}$ & $\begin{array}{l}\text { Aplicável aos } \\
\text { britânicos }\end{array}$ & Aplicável & $\begin{array}{c}\text { Alguns } \\
\text { indicadores } \\
\text { conseguem } \\
\text { ser aplicados }\end{array}$ & Aplicável & $\begin{array}{c}\text { Aplicável } \\
\text { com algumas } \\
\text { restrições }\end{array}$ \\
\hline $\begin{array}{l}\text { Indicadores- } \\
\text { Aplicação }\end{array}$ & Dificil & $\begin{array}{c}\text { Mediana -é } \\
\text { difícil traduzir } \\
\text { os dados numa } \\
\text { porcentagem } \\
\text { de } 0 \text { a } 100\end{array}$ & Mediana & $\begin{array}{l}\text { Mediana - } \\
\text { as } \\
\text { preocupações } \\
\text { são genéricas }\end{array}$ & $\begin{array}{c}\text { Mediana - } \\
\text { alguns créditos } \\
\text { possuem vários } \\
\text { indicadores } \\
\text { complexos }\end{array}$ \\
\hline $\begin{array}{l}\text { Realidade } \\
\text { brasileira }\end{array}$ & $\begin{array}{l}\text { Não se } \\
\text { aplica }\end{array}$ & Aplicável & $\begin{array}{c}\text { Alguns } \\
\text { indicadores }\end{array}$ & Aplicável & Aplicável \\
\hline $\begin{array}{l}\text { Conjuntos } \\
\text { habitacion } \\
\text { ais }\end{array}$ & $\begin{array}{l}\text { Aplicável aos } \\
\text { britânicos }\end{array}$ & Aplicável & $\begin{array}{c}\text { Alguns } \\
\text { indicadores }\end{array}$ & Aplicável & Aplicável \\
\hline $\begin{array}{l}\text { Áreas } \\
\text { urbanas }\end{array}$ & $\begin{array}{l}\text { Aplicável aos } \\
\text { britânicos }\end{array}$ & Aplicável & $\begin{array}{c}\text { Alguns } \\
\text { indicadores }\end{array}$ & Aplicável & Aplicável \\
\hline $\begin{array}{l}\text { Estrutura do } \\
\text { método }\end{array}$ & $\begin{array}{c}\text { Lista de } \\
\text { verificação }\end{array}$ & $\begin{array}{c}\text { Ponderação } \\
\text { - Excel }\end{array}$ & $\begin{array}{c}\text { Ponderação } \\
\text { - Excel }\end{array}$ & Perfil & $\begin{array}{c}\text { Lista de } \\
\text { verificação }\end{array}$ \\
\hline $\begin{array}{l}\text { Pontos } \\
\text { positivos }\end{array}$ & $\begin{array}{l}\text { Estrutura } \\
\text { simples, } \\
\text { rapidez na } \\
\text { aplicação }\end{array}$ & $\begin{array}{l}\text { Indicadores } \\
\text { sociais, } \\
\text { abrangente }\end{array}$ & $\begin{array}{l}\text { Completo - } \\
\text { aborda todas as } \\
\text { áreas de um } \\
\text { empreendiment } \\
\text { o sustentável }\end{array}$ & $\begin{array}{l}\text { Aborda } \\
\text { áreas } \\
\text { urbanas }\end{array}$ & $\begin{array}{l}\text { Estrutura } \\
\text { simples }\end{array}$ \\
\hline $\begin{array}{l}\text { Pontos } \\
\text { negativos }\end{array}$ & $\begin{array}{l}\text { Específico } \\
\text { ao contexto } \\
\text { britânico }\end{array}$ & $\begin{array}{l}\text { Falta de } \\
\text { precisão, } \\
\text { subjetivo }\end{array}$ & $\begin{array}{l}\text { Estrutura difícil } \\
\text { de ser entendida } \\
\text { - programa no } \\
\text { excel dificulta a } \\
\text { avaliação }\end{array}$ & $\begin{array}{l}\text { "Engessado } \\
\text { "- o perfil } \\
\text { restringe } \\
\text { outras } \\
\text { possíveis } \\
\text { combinações } \\
\end{array}$ & $\begin{array}{c}\text { Muitos } \\
\text { indicadores } \\
\text { voltados à } \\
\text { redução do } \\
\text { uso do } \\
\text { automóvel }\end{array}$ \\
\hline
\end{tabular}

Com exceção do Ecohomes, todos os métodos apresentaram a possibilidade de serem aplicados à realidade brasileira. $O$ que variou apenas foram os indicadores e como estes se organizavam dentro do método.

Dos cinco métodos avaliados, o SBTool é o mais completo pois considera em sua avaliação todos os aspectos passíveis de serem avaliados numa edificação ou num empreendimento O SBTool apesar de conter vários 
indicadores relacionados ao desenho urbano e à relação do empreendimento com seu entorno, dá uma peso muito grande à avaliação do consumo de recursos e das emissões, dois itens que não puderam ser avaliados nos conjuntos.

Uma dificuldade do método é a sua complexidade. Como uma iniciativa acadêmica, ele atende ao que se propõe, mas talvez sua operacionalização seja um pouco complicada, principalmente por estar baseado no Excel que varia de um computador ou versão de aplicativo para outros, ou pela facilidade em se alterar fórmulas e dados, basta um "clique" numa célula errada para se alterar alguma importante estrutura do método.

Em relação à forma como os métodos são estruturados, foi possível concluir que a estrutura atende ou não atende é mais objetiva que uma estrutura baseada em porcentagens ou conceitos. Neste ponto tanto o SBTool quanto o SBAT parecem precisar de um pouco mais de exatidão, como foi comentado anteriormente eles dão margem à subjetividade do avaliador quando, por exemplo, existe um valor intermediário entre os valores estabelecidos ou quando é necessário escolher um valor dentro de uma escala para traduzir um determinado conceito.

$\mathrm{Na}$ ponderação dos sistemas, os pesos usados nestes dois métodos ficam ocultos, o SBAT não explicita ao avaliador como funciona o sistema de pesos, e o SBTool apesar de existir uma ponderação no começo da avaliação também não deixa claro como estes pesos estão sendo usados porque as fórmulas são extensas e complexas. Neste ponto o esquema de lista de verificação do LEED-ND, do Ecohomes e a organização em perfil do AQUA são mais transparentes. É mais fácil verificar como e porque o empreendimento não foi bem avaliado num determinado requisito.

A avaliação pelos cinco métodos teve a função não apenas de analisar a aplicabilidade dos métodos, mas também de verificar quais as deficiências dos conjuntos habitacionais em relação ao que está sendo praticado internacionalmente na construção de unidades habitacionais.

Uma observação importante deve ser feita: os métodos foram elaborados para realidades de países desenvolvidos, onde o poder aquisitivo médio da população é muito mais alto que o do brasileiro. Em alguns métodos, 
em que foi avaliado o consumo eficiente de água e de energia, o desempenho do conjunto foi excelente principalmente porque não existe poder aquisitivo para um consumo maior. A média do consumo de uma família de baixa renda de um conjunto habitacional não chega $18 \%$ do consumo de uma família americana ${ }^{11}$. E este é um ponto positivo do método Ecohomes que tem que ser destacado: a avaliação do uso da água e da energia é feita por indicadores de desempenho que levam em consideração o consumo dos dois recursos.

Nesse sentido o consumo de uma família brasileira é extremamente mais eficiente que o de uma família americana, por exemplo. O consumo médio de energia de uma família norte-americana varia entre 900 a $1200 \mathrm{kWh}$ por mês ${ }^{12}$ enquanto uma família de conjunto habitacional brasileira não chega a $220 \mathrm{kwh} / \mathrm{mês}$. Em relação ao uso eficiente da água acontece o mesmo: enquanto o consumo médio norte-americano chega a quase $500 \mathrm{~m} 3$ por mês, a família de conjunto habitacional brasileira não chega a $10 \mathrm{~m} 3$ por mês. Uma das razões deste baixo consumo é o baixo poder aquisitivo da população.

Pode-se dizer que com relação às práticas ambientais, a indústria da construção civil brasileira está começando a se preocupar com procedimentos de construção sustentável, e os processos construtivos em sua maioria ainda apresentam grande impacto ambiental, principalmente se a autoconstrução for considerada. No caso dos assentamentos informais, ocupa-se onde se quer e constrói-se o que se bem entende, não há legislação que consiga impedir as invasões que contaminam mananciais e expõem seus ocupantes a diversos riscos ambientais como deslizamentos e inundações.

Nenhum dos conjuntos conseguiu atender os requisitos de uso racional da água por reuso da água pluvial ou cinza. Não há ainda uma legislação sobre o reuso de água ou o provimento do excedente de energia localmente produzida que pode ser jogado na rede, isto dificulta a implantação de pequenas estações de energia alternativa, pois as tornam inviáveis economicamente.

Indicadores relacionados à luz do dia ou iluminação natural e insolação alcançaram nível máximo, pelo Brasil ser um país de clima tropical ao contrário

${ }^{11}$ www.aneel.gov.br. TARIFAS PARA O FORNECIMENTO DE ENERGIA ELÉTRICA Resolução No. 627/ANEEL DOU de 08/04/2008.

12 http://www.eia.doe.gov/emeu/reps/enduse/er_contents.html. 
dos países onde os métodos foram desenvolvidos, nos quais a insolação é menor.

Indicadores relacionados ao adensamento local e à localização do terreno perto de serviços e transporte foram atendidos no seu nível mais alto: os conjuntos habitacionais se localizam em áreas densas e servidas por alguns serviços. O problema são serviços mais complexos como hospitais e principalmente centros de emprego, que normalmente ficam em áreas nobres das cidades a horas de distância das áreas menos valorizadas onde se localizam os conjuntos.

Os materiais da construção configuram um grande obstáculo a ser ultrapassado, pois não há quase nenhum dado sobre a matéria-prima e o processo de manufatura.

A questão social precisa ser abordada mais profundamente tanto em relação à mão de obra, como em relação à comunidade local. Nesse sentido, o SBAT e o SBTool foram os únicos métodos que levam em consideração algumas questões sociais. O SBAT ainda mais que o SBTool, principalmente por sua origem.

Apesar do Atibaia D possuir em seu projeto áreas verdes e espaços de lazer diferenciados que representam uma necessidade dos conjuntos habitacionais, mas que configuram uma grande dificuldade durante a operação do conjunto. Como pôde ser constatado no Conjunto Marechal Tito, estas áreas são abandonadas ou são impermeabilizadas pela própria população para que sua manutenção seja mais fácil.

Um ponto importante, a ser destacado, é a dificuldade enfrentada pelos projetistas em desenvolver o projeto de um empreendimento sustentável. Este tipo de empreendimento requer uma visão sistêmica e trabalho de equipe constante, ao contrário do modo tradicional em que o projeto é desenvolvido como uma linha de produção: cada um faz a sua parte e passa para o setor adiante. O projeto de um empreendimento sustentável precisa ser desenvolvido sob as diretrizes da construção sustentável desde a fase de concepção. Uma das principais contribuições do desenvolvimento dos métodos de avaliação foi colaborar para o processo de projeto, uma vez que podem funcionar como listas de verificação para os princípios de desenvolvimento sustentável. Além 
do processo de projeto é necessário um acompanhamento durante a obra e depois durante a operação para que as principais características de sustentabilidade se mantenham.

$O$ que aconteceu ao conjunto Atibaia $D$ foi o contrario. $O$ conjunto foi concebido desde o início sob uma série de princípios de sustentabilidade, mas que foram se perdendo no decorrer do desenvolvimento do projeto final e da obra, e o que se constatou a partir da avaliação dos métodos foi um baixo desempenho ambiental se comparado ao início do projeto.

De uma maneira geral, pode-se dizer que os métodos são aplicáveis à realidade brasileira. No entanto vários indicadores devem se adequar a esta mesma realidade para que a avaliação de um empreendimento sustentável seja real em todos os níveis, seja no nível mais geral que é o internacional em que todos prevêem uso eficiente da água e da energia, consumo responsável de recursos etc., seja nos níveis mais específicos de sustentabilidade que são os nacionais, os regionais e os locais, que exigem atendimento a necessidades específicas.

\subsection{SUGESTÕES PARA ESTUDOS FUTUROS}

Esta pesquisa limitou-se a analisar a aplicabilidade dos métodos internacionais e seus indicadores aos conjuntos habitacionais brasileiros. Foram estudados cinco métodos com o enfoque para áreas urbanas. Os resultados da pesquisa mostram que é necessário um levantamento das prioridades brasileiras sobre o que se será avaliado, sobre a definição de quais serão os parâmetros de sustentabilidade brasileiros para que um método avalie corretamente o que é ou não é sustentável para o contexto local.

Outros estudos precisam ser desenvolvidos para que os novos conjuntos consigam suprir as necessidades das famílias e pessoas para as quais são destinados, para que consigam atender a demanda pelo déficit habitacional e que possam oferecer um mínimo de qualidade de vida não somente aos seus moradores, mas à Cidade como um todo, causando um baixo impacto ambiental. 
Uma constatação a partir dos estudos de caso é que não há qualquer planejamento para a manutenção das áreas comuns dos conjuntos. A fase de uso e operação também precisa ser planejada e estruturada de acordo com as necessidades dos futuros moradores. A manutenção é difícil, porque sem verba ou tempo disponível para estes trabalhos, a população as abandona deixando que se degradem.

Pesquisas futuras no campo da habitação sustentável podem abordar a realidade dos assentamentos informais que estão sendo regularizados, como é o caso das favelas urbanizadas, dos cortiços e dos loteamentos clandestinos sob o aspecto da sustentabilidade.

A questão da densidade urbana nos seus diversos aspectos precisa ser aprofundada no Brasil, o LEED-ND, levantou diversos indicadores como densidade de ruas, densidade de unidades habitacionais por área, mas os parâmetros foram estabelecidos para um método desenvolvido num país com características bem diferentes das brasileiras. Talvez os parâmetros para a realidade brasileira sejam outros como a questão do transporte público e 0 desenvolvimento da cidade. 


\section{REFERÊNCIAS:}

ADEME - Agence d l'Environnement et de la Maitrise de l'Energie. Bats \& HQE. ADEME, Paris: 2006.

ADEME. Méthode en 100 fiches pour une approche environnementale sur I'urbanisme AEU. Le moniteur Paris: 2006.

ANGEL, S. et al. The Dynamics of Global Urban Expansion. Transport and Urban Development Department The World Bank, 2005.

ANDRADE, M.C. Geografia Econômica. São Paulo: Atlas, $12^{a}$ edição, 1998

ASSOCIATION Haute qualité Environmentale . Référentiel. Définition explicite de la qualité environnementale. Référentiels des caractéristiques HQE. Document 5. Paris, Association HQE, 15 novembre 2001a, 25 p.

ASSOCIATION Haute qualité Environmentale . Référentiel du système de management environnemental pour le maître d'ouvrage concernant des opérations de construction, adaptation ou gestion des bâtiments. Document provisoire - 23 novembre 2001. Paris, Association HQE, novembre 2001b, $15 \mathrm{p}$

Association HQE - HQE mode d'emploi. Paris: ADEME. 2006

ATIBAIA, Lei $n^{\circ} 3463$ de 31 de março de 2005 publicada pela Prefeitura da Estância de Atibaia.

Disponível em http://www.atibaia.sp.gov.br/legislacao/index.asp.

BARBOSA, W. R. et al. Implementação dos conceitos de ecodesign em projeto habitacional de interesse social. Brasil - São Paulo, SP. 2002. p. 952-961. NUTAU'2002. Artigo Técnico

BARTON, H. Conflicting perceptions of neighborhood, In: Sustainable Communities, org. Barton H. London : Earthscan Publications, 2000a.

BARTON, H. The neighborhood as a System, In: Sustainable Communities, org. Barton H. London : Earthscan Publications, 2000(b)

BEATLEY, T. \& MANNING, K. The ecology of the place: planning for environment, economy and community. Washington DC: Island Press, 1997.

BELLEN, H. M. Indicadores de sustentabilidade : uma análise comparativa, Rio de Janeiro: FGV, 2005

BONDUKI, N. G. Origens da habitação social no Brasil (1930-1945): o caso de São Paulo. São Paulo, SP, 1994. Originalmente apresentada como tese de doutorado. Faculdade de Arquitetura e Urbanismo - Universidade de São Paulo. 
BRE -Building Research Establishment. EcoHomes 2006 - The environmental rating for homes. The Guidance - Issue 1.2. April, 2006. Disponível em: www.ecohomes.org. Acesso em 2 fev 2007

BRE -Building Research Establishment. EcoHomes 2006 - The environmental rating for homes. The worksheets. April, 2006. Disponível em: www.ecohomes.org Acesso em 2 fev 2007

BRE -Building Research Establishment. EcoHomes 2006 - The environmental rating for homes. Pre-assessment estimator. April, 2006. Disponível em: www.ecohomes.org Acesso em 2 fev 2007

BRE -Building Research Establishment. EcoHomes 2006 - The environmental rating for homes. Developer sheets. August, 2006. Disponível em:

www.ecohomes.org Acesso em 2 fev 2007

BUNTLAND, G.H. Our common future: The World Comission on Environment and Development. Oxford: Oxford University Press. 1987. 398p.

CARDOSO. F.F.; DEGANI, C.M. Avaliação Ambiental de Edifícios. A Experiência Francesa e a Realidade Brasileira. In: X Encontro Nacional de Tecnologia do Ambiente Construído. I Conferência Latino-Americana de Construção Sustentável (ENTAC/claCS'04). São Paulo, 18-21 julho 2004. Artigo completo no CD-ROM do evento. ISBN 85-89478-08-4

CARDOSO, Francisco. Certificação de "empreendimento comercial de elevado desempenho ambiental 2002" disponível em:

http://www.pcc.usp.br/fcardoso/Certifica\%C3\%A7\%C3\%A30\%20Fran\%C3\%A7 a\%20HQE\%20portugues.pdf. Acesso em 02/07/2007

CARLO, J. Desenvolvimento de Metodologia deAvaliação da Eficiência

Energética do Envoltório de Edificações Não-residenciais. Tese submetida à Universidade Federal de Santa Catarina. Florianópolis, 2008.

CATHORPE, The Region in The "New Urbanism": toward an architecture of community. New York : McGraw-Hill, 1994. 245p.

CEC The green paper on the urban environment, Commission of the European Community, Brussels, 1990

CDHU - Manual Técnicos de Projetos - versão de 1998.

CHARLOT-VALDIEU, Catherine et al. Brochure $\mathrm{HQE}^{2} \mathrm{R}$ no 2 - The $\mathrm{HQE}^{2} \mathrm{R}$ toolkit for sustainable neighbourhood regeneration and European application overview. CSTB: March, 2004.

CHARLOT-VALDIEU, Catherine \& OUTREQUIN, Philippe. State of the art review of indicators and systems of indicators. CSTB: December, 2002

CIB. Agenda 21 for sustainable construction. CIB World, 2000. http://www.cibworld.nl/website/priority_themes/agenda21.php 
CIB \& UNEP-IETC. Agenda 21 for sustainable construction in developing countries - a discussion document CIB \& UNEP-IETC Pretoria 2002. http://www.cibworld.nl/website/priority_themes/agenda21.php

COLE, R. J. Building environmental assessment methods:clarifying intentions. Building, Research \& Information, 27(4/5), 230-246. 1999

COLE, R. J.; LARSSON, Green building challenge: lessons learned from GBC'98 and GBC2000 in: Proceedings SB2000 Maastricht, NOVEM/CIB/GBC, p. 213-215 October22-25, 2000

COLE, R. J. Building Environmental assessment methods: redefining intentions and roles. Building Research \& Information. v.33, n.5, p. 455-467. Especial Issue: Regionalism and Sustainability: Lessons from SB04. September-October 2005.

COLTRINARI, L. A urbanização na bacia sedimentar de São Paulo: Itaim Paulista e Itaquera. In: Geografias da Metrópole, org Carlos, A. F. A. \& Oliveira, A. U., São Paulo: Ed. Contexto, 2006

DCLG - Department for Communities and Local Government. Code for Sustainable Homes. Technical Guide. Department for Communities and Local Government: London. March, 2007. Disponível em: www.communities.gov.uk. Acesso em 20 junho 2007

Environment Protection Agency EPA http://www.epa.gov/smartgrowth/index.htm, último acesso em 04/04/2008

European Commission The HQE ${ }^{2}$ R project overview and the HQE2R approach synthesis. Web site: hqe2r.cstb.fr. Acesso em 20 maio 2007

FAVA, J. (editor) SETAC. A technical fromwork for Life-Cycle Assessments. Washington DC. SETC, 1991. 134p.

FIGUEIREDO, L. M. D. Uso de Ecodesign no planejamento e construção de núcleos habitacionais, in: Anais da I Conferência Paulista de Produção + limpa, São Paulo: 23 a 26 de julho de 2002,

FILION, P. \& MCSPURREN, K. Smart Growth and development reality: the difficult co-ordination of land use and transport objectives. Urban Studies vol.44, $n^{\circ} 3$, p501 a 523, março de 2007.

FOSSATI, M. Metodologia para avaliação da sustentabilidade de projetos de edifícios: o caso de escritórios em Florianópolis. Originalmente apresentado como tese de doutorado. Universidade Federal de Santa Catarina, Florianópolis 2008. 
FREITAS, G. et al. Habitação e meio ambiente. Abordagem integrada em empreendimentos de interesse social. São Paulo: Instituto de Pesquisas Tecnológicas. 2001.

GIBBERD, J. The Sustainable Building Assessment Tool - assessing how buildings can support sustainability, in Developing Countries, Continental Shift2001, IFI International Conference, 11-14 September 2001, Johannesburg, South Africa

GIBBERD, Jeremy. Integrating Sustainable Development into Briefing and Design Processes of Buildings in Developing countries: An Assessment Tool. Tese de doutorado. University of Pretoria, department of Architecture 2003

IBEC - Institute for building Environment and Energy Conservation. CASBEE for New Construction. Tool-1. Manual. 2004.

IBGE, censo de 2000

http://www.ibge.gov.br/home/mapa_site/mapa_site.php\#download.Último acesso em 04/2008

INOUYE, K.P. Indicadores físicos de urbanização para subsidiar a avaliação de custos de conjuntos habitacionais horizontais de interesse social. Dissertação Escola Politécnica, Universidade de São Paulo, 2003.

KAATZ, EWELINA; BARKER, GREG; HILL, RICHARD; BOWEN, PAUL. A comparative evaluation of building environmental assessment methods: suitability for the South African context In: SB02., 2002, Oslo, Norway..

Katz, P.The "New Urbanism": toward an architecture of community. New York: McGraw-Hill, 1994. 245p.

KNAAP, G. \& TALEN, E. "New Urbanism" and Smart Growth: a few words from the Academy. International Regional Science Review, vol. 28, $n^{\circ}$ 2. p. 107-118. 2005

LARSSON, N. An Overview of green building rating and labeling systems. liSBE: 2004.Disponível em http://greenbuilding.ca/iisbe/start/iisbe.htm. Acesso em 20/05/2007

LARSSON, N. An overview of SBTool, June 2007 Release. liSBE: 2007. Disponível em: http://www.iisbe.org/iisbe/sbc2k8/sbc2k8-download_f.htm. Acesso em 26/06/2007

Ministério do Meio Ambiente -MMA. Agenda 21 brasileira: resultado da consulta nacional 2. ed. Brasília : Ministério do Meio Ambiente, 2004.

MORETTI, R.S. Normas Urbanísticas para habitação de interesse social: recomendações para elaboração. São Paulo: Instituto de Pesquisas Tecnológicas, 1997. 
MOTA, S. Urbanização e meio ambiente. Rio de Janeiro: ABES, 1999. 352p.

NOBREGA, R. A. A. ; OHARA, C. G. ; QUINTANILHA, J. A. . Detecting roads in informal settlements surrounding Sao Paulo city by using object-based classification In: OBIA'06 - 1st International Conference on Object-Based Image Analysis, 2006, Salzburg.: Universität Salzburg, 2006

PERRIN, J.C. Le Développement Regional. Paris: Presses Universitaires de France, 1974.

PREFEITURA DO MUNICÍPIO DE SÃO PAULO, site: www.prefeitura.sp.gov.br, acesso em 30/03/2006.

RYKWERT, J. A sedução do lugar : a história e o futuro da cidade. São Paulo: Martins Fontes, 2004.

ROCHEFORT, M. Redes e Sistemas. Ensinando sobre o urbano e a região. São Paulo: Hucitec, 1998.

SACHS, I. Caminhos para o desenvolvimento sustentável. São Paulo: Garamond. $4^{\mathrm{a}}$ ed. 2002.

SACHS, I. Rumo à Ecossocioeconomia. São Paulo: Cortez. $1^{\text {a }}$ ed. 2007.

SBIS - site: www.sbis.info. Acesso em 31/03/2006

SEDREZ, M.Sustentabilidade do ambiente construído: contribuições para a avaliação de empreendimentos habitacionais de interesse social. Dissertação de mestrado, Universidade Federal do Rio Grande do Sul, 2004.

SETUR, Guide d'experimentation a l'usage des amenageurs - Document definitif - Janvier 2006.

SILVA, V.G. Avalição de sustentabilidade de edifícios de escritórios brasileiros: diretrizes e base metodológica. São Paulo, Originalmente apresentada como tese de doutorado. Universidade de São Paulo, 2003

STEAD, D. Unsustainable Settelmentes In: Sustainable Communities, org. Barton H. London : Earthscan Publications, 2000

TALEN, E. Measuring urbanism: issues in Smart Growth Research. Journal of Urban Design, vol.8, no 3, p.195-215, October, 2003.

TAYLOR, N. Eco-Villages: Dream and Reality. In: Sustainable Communities, org. Barton H. London : Earthscan Publications, 2000 
UDALL, Randy \& SCHENDLER, Auden. LEED is broken-Let's fix it.. Disponível em: www.igreenbuild.com/cd_1706.aspx. iGreenBuild:2005. acesso em 27 de junho de 2007

UN-HABITAT. The habitat agenda (Agenda Habitat II). Istanbul: UN-HABITAT, 1996

USGBC, Guidelines for LEED - ND:

http://www.usgbc.org/DisplayPage.aspx?CategorylD=19. Acesso em 13.03.2006.

USGBC et al. LEED for Neighborhood Developments Rating System Preliminary Draft. September, 2005.

USGBC et al. LEED for Neighborhood Development Rating System - Pilot Version. 2007

VANZOLINI, FUNDAÇÃO. Referencial Técnico de Certificação "Edifícios do setor de serviços - Démarche HQE®". 2007.

WALSH, E. et al Quantitative guidelines for urban sustainability. Technology in Society 28 p. 45-61. 2006

WERNA, E. et al. Pluralismo na habitação. São Paulo: Annablume, 2001 